University of Louisville

ThinkIR: The University of Louisville's Institutional Repository

\title{
(An)other gender : a cross-cultural analysis of war-torn France and Great Britain in which Simone de Beauvoir and Virginia Woolf redefine "woman".
}

Anna Stamp 1979-

University of Louisville

Follow this and additional works at: https://ir.library.louisville.edu/etd

\section{Recommended Citation}

Stamp, Anna 1979-, "(An)other gender : a cross-cultural analysis of war-torn France and Great Britain in which Simone de Beauvoir and Virginia Woolf redefine "woman"." (2011). Electronic Theses and Dissertations. Paper 1371.

https://doi.org/10.18297/etd/1371

This Doctoral Dissertation is brought to you for free and open access by ThinkIR: The University of Louisville's Institutional Repository. It has been accepted for inclusion in Electronic Theses and Dissertations by an authorized administrator of ThinkIR: The University of Louisville's Institutional Repository. This title appears here courtesy of the author, who has retained all other copyrights. For more information, please contact thinkir@louisville.edu. 
(AN)OTHER GENDER:

A CROSS-CULTURAL ANALYSIS OF WAR-TORN FRANCE AND GREAT BRITAIN IN WHICH SIMONE DE BEAUVOIR AND VIRGINIA WOOLF REDEFINE "WOMAN"

\section{$\mathrm{By}$}

Anna Stamp

B.A., University of Louisville, 2001

M.A., University of Louisville, 2003

A Dissertation

Submitted to the Faculty of the

College of Arts and Sciences of the University of Louisville

In Partial Fulfillment of the Requirements

For the Degree of

Doctor of Philosophy

Department of Humanities

University of Louisville

Louisville, Kentucky

August 2011 
(An)Other Gender:

A Cross-Cultural analysis of war-torn France and Great Britain in which Simone de Beauvoir and Virginia Woolf redefine "Woman"

By

Anna Stamp

B.A., University of Louisville, 2001

M.A., University of Louisville, 2003

A Dissertation Approved on

July 25, 2011

by the following Dissertation Committee:

Dissertation Director (Suzette Henke)

Annette Allen

Osborne P. Wiggins

Nancy M. Theriot 


\section{DEDICATION}

This dissertation is dedicated to my parents

Mary Anne and Richard W. Stamp,

who have always believed I could do anything,

to my husband

Tanney M. Bradley Jr.

who never doubted me for one single moment,

and finally to the little person who may not be here yet,

but who nonetheless became my ultimate motivation down the home stretch. 


\section{ACKNOWLEDGMENTS}

I would like to thank my dissertation committee chair, Dr. Suzette Henke, for her guidance and inspiration throughout my $\mathrm{PhD}$ program and the dissertation process. Her tireless editing and suggestions made me a better writer. I would also like to thank my committee members, Dr. Annette Allen and Dr. Osborne Wiggins for their support over the past several years, and Dr. Nancy Theriot for taking the time to read my work and lend her support to my efforts. Great thanks must go to my husband, Tanney, for his constant encouragement, even when I did not want it. I also give many thanks to my parents, Mary Anne and Richard, without whom I would not have made it through my my $\mathrm{PhD}$ program. 


\begin{abstract}
(AN)OTHER GENDER:

A CROSS-CULTURAL ANALYSIS OF WAR-TORN FRANCE AND GREAT BRITAIN IN WHICHH SIMONE DE BEAUVOIR AND VIRGINIA WOOLF REDEFINE "WOMAN"
\end{abstract}

\title{
Anna Stamp
}

July 25,2011

This dissertation is a cross-cultural analysis of France and Great Britain during both the First World War and World War II in which Simone de Beauvoir and Virginia Woolf redefined "woman." Utilizing New Historicism, the first chapter begins with a focus on the evolution of the two cultures from the mid-nineteenth to early twentieth century France and Great Britain and discusses the ways in which the women's movement was both perpetuated and hindered by the volatile political and cultural climates of these two countries. The second chapter discusses the traditional woman as she was viewed in both French and British culture as depicted in the works of Simone de Beauvoir and Virginia Woolf. Specifically, the images of the mother, wife, hostess, and socialite are viewed in order to develop the definition of what a traditional woman was during the first half of the Twentieth Century in Great Britain and France. The third chapter lays the theoretical and philosophical ground work for the argument of An(Other) gender. Existentialism and phenomenology allow for a philosophical validation of this idea. Chapter four utilizes examples from Woolf's fictional works, such as Mrs. Dalloway, and Beauvoir's The Second Sex in order to analyze the definition of the traditional woman. This chapter is not comparing genres but rather re-visiting Woolf's works through the lens of Beauvoir's The Second Sex as she clearly describes the traditional role of women as dictated by patriarchal 
domination. Chapter five seeks to explore Woolf and Beauvoir's attempts at (re)defining (an)other gender. Louis Althusser's Ideological State Apparatus (ISA) is used to contemplate the place of "woman" at the time of Woolf and Beauvoir both in the home and as an emerging figure in society. 


\section{TABLE OF CONTENTS}

Page

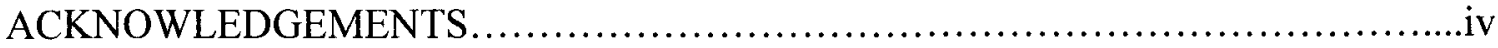

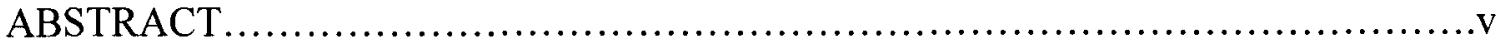

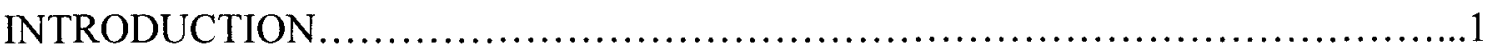

Chapter One: Was the End worth the Means? Women take to the social battlefield.......7

Women of Great Britain: No man's Land=Woman's Land?...............................8

French Female Suffrage: "A task that requires the genius of Napoleon and the

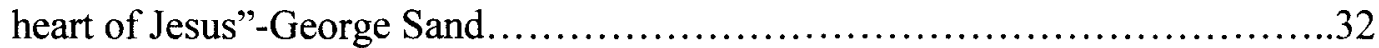

Virginia Woolf and Simone de Beauvoir.................................46

Chapter Two: The Lady of the House in French and British Cultures...................50

The Wife/Mother: The Family Woman.....................................53

The Keeper of the House: Cleaning All The Private Parts.......................6 63

Chapter Three: Viewing Virginia Woolf and Simone de Beauvoir through a philosophical

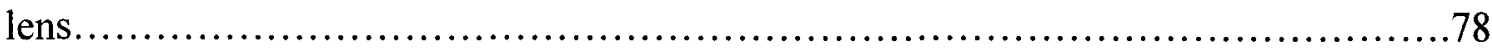

Woolf and Beauvoir's Existential and Phenomenological Roots................80

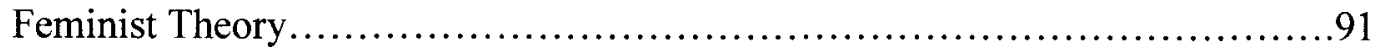

Chapter Four: Mrs. Dalloway is the Second Sex: Re-reading Woolf's Women through the

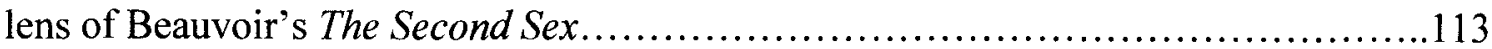

The Tradition of Social Life: "Remember my party tonight!".................116

An Unexpected Guest: Death at the Party................................... 126

The Young Girl: "She is awaiting Man".................................... 132

The Wife and Mother: You Can't Have One Without the Other!......................147 
Chapter Five: (An)Other Gender: "One is not born but rather becomes. .." ............158

Ideological State Apparatus: Can She Really Be Free?.......................................161

(An)Other Gender: Orlando and A Third Sex..............................172

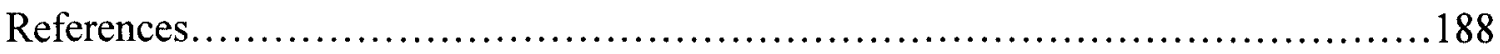

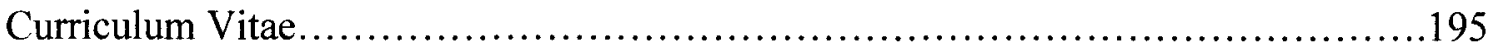




\section{INTRODUCTION}

During the first part of the Twentieth century, while the European continent was devastated by the atrocities of war, the inability to express realistically what it meant to be an authentic human subject in the world was a modern dilemma. Specifically, the social paradigms were shifting, and the definitions of roles, especially those pertaining to gender, were being revised so as to fit the emergence of the New Woman. However, this emergence did not come without problems. The New Woman in society created great social and political anxieties in a largely patriarchal culture, and at times, this gender struggle began to reflect the battles being fought at the front during the First World War as well as World War Two. A cross-cultural analysis and definition arose out of the state of things in a war-torn world. Traditional gender roles were no longer efficacious or workable. Thus a new definition had to evolve. Virginia Woolf's polemical works $A$ Room of One's Own (1929) and Three Guineas (1938) question a woman's place in modern society. Woolf's fictional works such as Mrs. Dalloway (1925) and To The Lighthouse (1927) which depict the traditional woman through Clarissa Dalloway and Mrs. Ramsay, and Orlando (1928) in which gender boundaries are destroyed as Orlando

lives as both a man and a woman, give insight into how the New Woman was viewed as the gender question was being posed during the first part of the twentieth century. 
Simone de Beauvoir too in The Second Sex (1949) was working to redefine Woman as she sought to make sense of this new world in which women were entering a public sphere still dominated by patriarchy. Both Woolf and Beauvoir also utilized their personal experiences in their autobiographical writings such as Woolf's Moments of Being and Beauvoir's Memoirs of a Dutiful Daughter, and each woman reflected upon the question "What did it mean to be a woman?" The balance of power in society shifted as war and industry prompted women to assume nontraditional roles in society, reshaping the world into a viable place for women.

With a social upheaval driven by the atrocities of war, a new awareness of being a self in the world opened up theoretically and realistically. Thus the so-called truths of the interconnectedness between gender and society were questioned: How does one define the self without gender classifications? Woolf and Beauvoir both experienced female identity dilemmas, for there was no way to express what the self was without the utilization of the male categories as "norm," thus placing female as "other." As Beauvoir claims in The Second Sex, "[Woman] is determined and differentiated with reference to man and not he with reference to her; she is the inessential as opposed to the essential. He is the Subject, he is the Absolute: she is the Other" (xxii). The binary gender system so prominent in "civilized" society seemed useless in attaining a clear understanding of the self outside of gender. How were women to define "subject positions" without using current masculine criteria? Major events such as the world wars and suffrage created a space in which new questions could be raised about how to negotiate a world of such change and devastation. Out of that devastation, could a new definition of gender emerge that no longer depended upon the binary gender system? Could human beings be defined 
or rather "un-defined" through the denial of biological considerations?

Considering what was important in defining who a person was during the first half of the twentieth century, both Woolf and Beauvoir explored the characteristics of an existential project as each denied the idea that truths about being can be discerned from considering gender. In both writers' opinions, gender was a tool, a fallacy used by patriarchy to force certain facts upon the female sex concerning their abilities to work, learn, and live among men in society. Beauvoir and Woolf both recognized the power of patriarchy to define what "woman" is and what she is not. Their arguments in their polemical prose as well as within memoirs and fiction portray the male definitions as antiquated. Beauvoir claims: "One is not born, but rather, becomes a woman," and Woolf takes Orlando across generations and across sexes, as he wakes from his slumber one morning and realizes that he is a woman. The binary gender system is insufficient in creating truths for a self. The self must be defined by the individual, based on personal experiences and personal desires outside of societal pressures. Definitions forced upon the self from the outside cannot authentically communicate an individual('s) experience. Truth is realized within.

The works coming from both Great Britain's Woolf and France's Beauvoir as the World Wars were being fought across the European landscape, and as women sought to redefine themselves uniquely, articulate a gender crisis. One must come to the conclusion that in order to satisfy this gender crisis in which women searched for the self, a unique entity, neither male nor female, would have to be envisaged -(an)other gender- an individual that was not confined within the definitions of patriarchy, but rather existed outside of current society which had traditionally been constructed and controlled by the 
masculine. And while Woolf and Beauvoir seem to be in agreement over the necessity of freedom from patriarchal rule, how to make that ideal an actuality was unknown. How is the "woman" instrumental in constructing her own definition of gender and how is this idea utilized in the works of Woolf and Beauvoir? In what ways does patriarchal society already dictate gender and how do Woolf and Beauvoir seek to re-define this power within modern culture? What is (An)Other Gender?

Virginia Woolf and Simone de Beauvoir were troubled by the inequities facing women in society, not just professionally, educationally, and economically, but biologically as well. Each woman wrote in fiction, polemical prose, and autobiography about the plight of women during these times, arguing for divergent thinking not just within society, but within the idea of a "female gender" as well. Previous ideas about who a woman was and what she was un(able) to achieve in society were being debunked as women moved out of the home and into society, fighting for the rights to work, learn and live as independent subjects capable of creating their own definitions based on personal experience rather than on anatomy.

The goal of this project is to present the difficulties of the "woman" question as it was being raised in social, political, and scientific circles during the war years of 19141945, encompassing not only the First World War, but World War II as well as the interwar years, and how Simone de Beauvoir positioned herself culturally in her native France, as Woolf did in Great Britain. It is important to allow for the broad span of time so that the inclusion of not just the wars, but also the development of Woolf and Beauvoir's thought and writing can be considered. Both France and Great Britain were in the midst of battle during both World Wars, and the traumatic experiences of these wars 
greatly affected both of these writers, and influenced their feminist manifestos. Beauvoir claims in The Second Sex "One is not born, but rather becomes, a woman" and in Three Guineas Woolf argues that regardless of 20 th century political advances, "Our class is the weakest of all the classes in the state. We have no weapon with which to enforce our will" (13).

The significance of such a project rests in taking the feminist discussion across borders and across wars, including 30 years of history, writing, and discovery. The inclusion of World War II allows for further exploration into the advancements of the women's movement beyond the right to vote, which was not granted to French women until July 1944, and beyond political liberties in order to stress the importance of an entire social shift that both Woolf and Beauvoir saw as essential for the true equality of women. By including Simone de Beauvoir, Virginia Woolf, and the impact of both World Wars upon their aesthetic, I am able to create a fuller picture of a feminist movement that sought to redefine the "feminist" agenda in more inclusive terms of humanist concerns.

The utilization of New Historicism allows for an exploration of Woolf and Beauvoir within their cultural contexts. Using this theory, we are able to view Woolf and Beauvoir within their revolutionary times and discern how different events impacted these women in similar ways. Specifically, the history of World Wars I and II and how they influenced not only the political landscape of France and Great Britain, but the entire social and cultural European landscape will be important focal points. Utilizing the works of Virginia Woolf and Simone de Beauvoir, including their fictional, autobiographical, and polemical writings, I will draw upon the feminist implications inherent in each of these authors' works, for these examples allow for a comparison of specific images of 
women at this time in two different countries.

A comparative analysis of the cultural worlds of Virginia Woolf and Simone de Beauvoir set up the argument that (An)Other definition of gender was created by Beauvoir and Woolf as they experienced war trauma and cultural shifts in their worlds. The purpose for the unusual spelling of "another" is that many have tried in the past to define and redefine gender roles. However, Woolf and Beauvoir not only give another definition, but seem to create an entirely Other gender, in which choice is inherent and personal experience trumps all other modes of definition. Woolf with her discussions of androgyny in fiction such as Orlando and non-fiction, such as $A$ Room of One 's Own, and Beauvoir, through her bold statement that one "becomes" a woman in The Second Sex, are not merely redefining gender via the binary gender system, but rather are seeking to define a new gender. The First World War and World War II had a profound effect on the women's movement both in France and Great Britain, and similarities can be found between the ideas of Simone de Beauvoir and Virginia Woolf as they each describe the traditional woman and the patriarchal power binding women to their domestic roles. 


\section{CHAPTER ONE: \\ WAS THE END WORHT THE MEANS? WOMEN TAKE TO THE SOCIAL BATTLEFIELD}

In order to grasp the complicated nature of "woman" during the modern period, one must look to the war waged not just upon the battlefield, but upon the social front as well. Both historical analysis of events happening across Europe and literature shed light upon the woman question during the nineteenth and twentieth centuries. Looking at the writing being produced by both men and women is useful in determining what it was like to be a woman at that time. Writers like Vera Brittain and Rebecca West, and activists like Millicent Garrett Fawcett, Eleanor Rathbone, and Christabel Pankhurst lend a socially and historically relevant perspective towards how women struggled in the battle for emancipation in Great Britain. So too in France, writers like Marie d'Agoult and George Sand, and men like Ernest Legouvé and Camille Sée tell the story of an early French women's movement that aided in attaining female suffrage.

Whereas the women's movement was ultimately successful during the 19 th and early 20 th centuries in obtaining the right to vote for women, women were by no means fully emancipated into a world still dominated and defined by male norms. Education, financial stability, and meaningful political power still remained under the control of the patriarchy and thus out of reach for women across Europe. Specifically in France and Great Britain, women fought for decades to improve the status of women in society, but efforts were always curtailed when societal norms became threatened by the seemingly 
aggressive nature of the suffrage movement. In 1918, some women in Great Britain won the right to vote, but it was not until 1944 that France followed suit. However, the right to vote did not alter the social situation in which these women were living in terms of independence, political power, financial stability, and education.

War played a crucial role in both helping and hindering the suffrage movement, for women as noncombatants aided a great deal in the war effort, but were sent home once their service was no longer needed. The First World War created a labor shortage, as many men had to abandon the work force in order to join the military effort, leaving factories empty. Women reacted in large numbers, moving out of the private sphere of the home into the public realm of the workplace. This new social role introduced women to a new economic independence, a new self-fulfillment, and created a need for a new definition of who she was. This search for a new female identity and authority during the war became public as suffrage demonstrations were taken to the streets. The war and the suffrage movement created a shift in women's desire to define the self differently than society had in the past. The identity of women moved from the strict confines of the private life of the wife, mother, and lover to the public life of the "New Woman," worker, voter, and war supporter or protester. No longer were the past definitions of Woman relevant, and women actively sought change.

\section{Women of Great Britain: No Man's Land=Woman's Land?}

As early as the 1840 's, British social feminists fought for the needs of women in society. Social feminists were "those women... who championed the cause of women's suffrage and the expansion of women's rights in the work place, but their highest 
priorities concerned the poor, both adult and children" (Cohen and Hanagan 470). In the article "The Politics of Gender and the Making of the Welfare State, 1900-1940: A Comparative Perspective," Miriam Cohen and Michael Hanagan explain that Social Feminists focused on areas such as protective legislation dealing with the limitation of female worker's hours, maternal and infant care, mothers' pensions, and family allowances. Making better a woman's lot in life was the primary goal of such feminists. As early as the 1830 s, a woman's right to her children was a source of concern for many feminist activists, for the hierarchy of the family was organized to uphold the father's dominion over his wife and children. According to Ann Allen in Feminism and Motherhood in Western Europe 1890-1970, "Caroline Norton gained for British mothers who were legally separated from their husbands the right to care for (though not to have legal custody of) their young children - and was included in the programs of the earliest feminists organizations" (45). Regardless of whether or not a mother was the more appropriate caregiver or the more knowledgeable parent, sole custody and power was routinely given to the father. Since paternity could never $100 \%$ be determined, and despite the fact that maternity could be determined, marriage became the way for men to claim children; whatever child his wife produced was automatically assumed to be his, and therefore, he took control of that child, and the mother had few rights to her own offspring. This mentality was not only present in Great Britain, but across the Continent as well, and was a primary concern for the early feminist activists who sought to redefine not only the laws of the state where maternity rights were concerned, but the idea of woman all together, to lend validity to her place in society as a mother, a wife, and a valuable member of society. 
However, if women were allowed more power in the decisions regarding children and if society acknowledged that woman was the more appropriate parent to exercise power over children, it would not make sense that women did not also share an equal role in the marriage, family, and thus society. Therefore, the power over the family remained under the control of the patriarch, for while it seemed as if mothers had power in the private sphere, they only exercised the rights given to them by their husbands.

The British suffrage movement in the1860s focused on hopes of equality for women. The right to vote, to have a useful education, and the ability to earn a living separate from that of fathers and husbands were the goals of this movement. To remove the barriers that had always blocked women from realizing their abilities as individual human beings was the aim of those first Suffragettes, many of whom never lived to see the results of the movement they began. The powerless and submissive role of women within their households mimicked the limited and powerless role women played within society. Without public power supported by educational and financial independence, private power could not be achieved, for the wife and mother had to depend upon her husband for support not only of herself but of her children since she had no means of taking care of them herself. The role of women in the home was not respected or compensated in any way, but a public role was not available to them. Society believed that women did not have much to contribute as their domestic roles held little value. This was the cycle in which the early feminists found themselves, and from which they fought to break free.

Traditionally, women's contributions to the health of a nation had always been primarily seen in terms of childbearing. She did not deserve the right to vote because she 
did not pay the "tax of blood" during war times and therefore had no claim to any political power. A woman's primary responsibility to her country was to provide it more citizens and raise those citizens within the confines of the private sphere. It was feared that if women had more rights and responsibilities in the home and in society, then they would forego their divinely prescribed roles as wives and mothers for more individual aims, thus destroying the family and society. Millicent Garrett Fawcett rejected this idea of "[linking] together the claims of woman to citizenship and social and industrial independence with attacks on marriage and family" (Allen 53). The early feminist activists were not necessarily interested in eradicating the traditional role of women as wives and mothers but rather, were interested in validating those roles with social and private power. They wanted women to have rights to contribute to their own homes and their own children without needing permission from the men ruling their families. As evidenced by Fawcett's sentiments, any indication that feminists were trying to derail the private home would damage their efforts.

It is not to say, however, that the family was always the sole concern of men in society in regard to women attaining power in the public sphere. Women had worked and been mothers for centuries, especially in the lower classes where it was a necessity for survival that both men and women worked outside of the home. However, women were consistently paid much lower wages than their male counterparts. During the nineteenth century, regardless of the financial necessity to mothers, children, and families in general, many believed that women must be removed from the public sphere at all costs and returned solely to the home due to the "moral disorder caused by the removal of women from the "natural' authority of father or husband" (Allen 64). And while this was the 
popular public opinion of the working woman's dilemma, there was another underlying fear that if so many women entered the work force while accepting a much lower wage than men, then female labor would be in much higher demand by employers, causing the husband or father to be unable to serve as primary bread winner and earn wages large enough to sustain a family on his own. These anxieties felt by many men in society would continue to exhibit themselves well into the First World War as it became necessary for women to take over previously male occupied positions while men went off to war. Men began to fear that women were taking over, gaining too much power, and creating a society in which male participation was considered obsolete.

During the years immediately preceding the First World War, Western Europe experienced a population crisis characterized by declining birthrates. Many governments blamed feminism and the desire for equality for this decline, believing that women were shirking the responsibility of motherhood for what were considered more selfish aims like education and money. Feminists responded by claiming that if motherhood was upheld as an important position in the home and in society, then women might be more inclined to participate in this reproductive role more frequently and with a more positive attitude: "Women's opposition [to motherhood] ... was not to motherhood itself, but to motherhood as a coerced service to a patriarchal family and state, and when free to control their own reproductive decisions, ... women would willingly become mothers" (Allen 88). Being forced to conform to the socially prescribed role of mother, without any other choice for self-definition, created an environment in which women resented their reproductive capabilities and sought ways in which to thwart reproduction. Ultimately, as 
the First World War came to Great Britain, women were ready to change their positions in society and actively sought ways to broaden their options in the public sphere.

Within the private sphere of the home, the power structure mimicked the hierarchy of the public world, where the man of the household reigned supreme and it was the woman's role to keep house, raise offspring, and remain submissive to her father, brother, or husband. However, with the onslaught of the First World War, her responsibilities changed, and with that, the definition of her social role needed to change as well.

British women were in the midst of the struggle for equality when Great Britain entered the First World War in August of 1914. However, because of the war issue, the women's movement had to take a secondary position regardless of the desire for the movement to succeed; war took precedence. Many feminists sought to turn this crisis to their advantage by showing the country that women were ready to serve the nation and its war effort as best they could by laying down the suffrage cause and becoming nurses or working in the factories that were now empty as men were shipped to the front. Women wanted to show solidarity with their fellow citizens and countrymen, lending support to the men who marched to the front, and many to their deaths. Two main feelings plagued women as they faced a new world carved out by the devastation of war - guilt and resentment- guilt for surviving and even flourishing while so many men perished, and resentment towards the establishment that denied them political power in solving the problems of the present or future. Women played non-combatant roles during the wars, and while they saw firsthand the carnage of the war and personally felt the effects of the fighting, women and their experiences were considered marginal. 
Women served in many capacities during wartime to aid the country and its soldiers. Unable to fight, many women became nurses working with the carnage and death of the war first hand. Women also replaced men in the factories across the countries, keeping the economic machine running while the war ravaged the European landscape: “In Britain, women's total workforce participation increased from about 25 percent to 47 percent, and their share in traditionally male industries increased still more: in building 320 percent, in metal work 249 percent" (Allen 113). According to Richard Badenhausen in "Mourning through Memoir: Trauma, Testimony, and Community in Vera Brittain's Testament of Youth," women held both public and private roles directly related to the war effort:

Most of their participation occurred on the borders of battle: at the edges of the front as nurses and other support staff, at work places as professional replacements for men off to fight, and at home as managers of depleted households who were forced to wait anxiously to hear the fate of family, friends, and neighbors serving their country. (422)

Women held important positions during the war, for without them, the state could not have been as productive. Interestingly enough, while women were being "forced" from the private sphere into the public sphere to fulfill a duty other than motherhood, it is in the public sphere they thrived. With the emergence of the "New Woman" in the public sphere, the old labels of what a woman was seemed to become obsolete, and a new definition of her social role was needed.

The search for an authentically "female" identity was a quest that concerned many women at the turn of the twentieth century. Female British writers utilized suffrage within their literary works in order to bring public attention to the need for equal rights. However, with a traumatic war claiming millions of lives across the battlefields of 
Europe, the focus was split between women's issues and the war. The role played by women during the war was undermined by society because women's efforts were not considered comparable to the efforts of men fighting on the battlefields. Although many people suffered great trauma during the war, men's combat experiences were the only actions considered traumatic. There was a gendering of legitimate criticisms about war and suffering. As Sandra Gilbert and Susan Gubar explain in No Man's Land: The Place of the Woman Writer in the Twentieth Century: "Such effects of the First War were gender-specific problems that only men could have. Still struggling to attain power, women could hardly worry about the loss of authority they had not yet fully achieved" (2: 260). Gilbert and Gubar comment on the connections between women's experiences, the war, and the women's movement. Based solely on gender, women's experiences during the war were viewed as less significant because of their lack of involvement in combat, regardless of the actual contributions they made to the war efforts.

Vera Brittain is a prime example of a woman who was concerned with women's issues and war experiences, and she wrote to critique the position of women in the maledominated home, as well as the male's sole claim to war trauma. Many women at this time sought to legitimate the female war experience, claiming that women too were involved and thus affected by the war. This argument is seen through Brittain's fictional works such as Honourable Estate (1936), and also in her memoir Testament of Youth (1933). Within these works, Brittain discusses her own war experiences and details the oppressive nature of women's limited roles. Brittain herself was brought up in an upper middle class family and was educated at Somerville College, but in June 1915 she volunteered as a nurse and over the next four years experienced extreme suffering as she 
not only tended the mangled bodies of soldiers from the front, but also grieved the loss of her closest male loved ones. Brittain claims that "women get all the dreariness of war, and none of its exhilaration" because women are unable to experience battle (TY 104). However, Brittain does mention in her memoir the valuable education she received during the war, despite her exclusion from battle:

Towards the men, I came to feel an almost adoring gratitude for their . . acceptance of my ministration. Short of actually going to bed with them, there was hardly an intimate service that I did not perform on one or another . . . and I [am] still thankful for the knowledge of masculine functioning which the care of them gave me. (TY 165-6)

According to Richard Badenhausen, Brittain became conflicted between her two opposing roles of "active participant (as nurse) and passive spectator (as mourner of the dead)" and how "those dual roles forced Brittain to wrestle, much like the shell-shocked male soldiers, with the effects of trauma on her own psyche" (422). Refusing to succumb to the marginalized social standing of women, Brittain creates her own legitimate connection between her war trauma and that of male soldiers through the construction of her memoir, Testament of Youth.

Other writers of the time also expressed the interconnectedness of the soldiers fighting at the front and the non-combatants, including women, suffering at home. Rebecca West's fictional work, The Return of the Soldier grapples not only with feminist issues connected to the war, but also the domination of patriarchy, and the slow progress of female advancement in society. Bonnie Kime Scott, in "Refiguring the Binary, Breaking the Cycle: Rebecca West as Feminist Modernist," explains the different themes West takes up in her works: "Rebecca West wrote her way into the major cultural dilemmas of the twentieth century: suffrage, socialism, women's employment, sexual 
liberation, war, treason, and communism. She grappled constantly with the laws of patriarchy. ..." (169). According to Bonnie Kime Scott in The Gender of Modernism, West wrote for the suffragist journal Freewoman, was deserted by her father, an antisuffragist journalist who left her family in 1901, and was acutely aware of a lack of female economic independence, which became a consistent theme throughout her works. West looked at shared war neuroses between the civilian and the soldier (560-1). According to Trudi Tate's Modernism, History and the First World War: "The idea of civilians suffering from war neuroses was by no means unknown during the Great War, and it turns up in a number of works of fiction, such as Rebecca West's The Return of the Soldier (1918), in which the civilian narrator suffers from war-neurotic dreams about the trenches" (13). West was attempting to legitimate the female war experience as traumatic regardless of actual combat participation. The returned soldier, Chris, has lost his memory and cannot remember his wife Kitty, but rather wants to spend time with a past love, Margaret. The pain, jealously, and disbelief felt by the women waiting for Chris's safe return is palpable throughout the novel and adds yet another layer to the war trauma experienced by women: "For a long time we watched [Margaret] as she went along the drive, her yellowish raincoat looking sick and bright in the sharp sunshine, her black plumes nodding like pines above, her cheap boots making her walk on her heels; a spreading stain on the fabric of our life" ( $R S 37)$. Regardless of these negative feelings, the narrator eventually comes to terms with the situation and becomes somewhat grateful to Margaret for her sacrifices in regards to the wellness of their "damaged male":

So it was not until now, when it happened to my friends, when it was my dear Chris and my dear Margaret who sat thus englobed in peace as in a crystal sphere, that I knew that it was the most significant as it was the loveliest attitude in the world. It means that the woman has gathered the soul of the man into her soul 
and is keeping it warm in love and peace so that his body can rest quiet for a little time. That is a great thing for a woman to do. $(R S 143-4)$

Jenny's realization of what Margaret is able to give Chris seems quite contradictory to the feminist agenda of West herself. It is as if West is celebrating the use of the female for male needs. However, as Victoria Glendinning explains in the introduction to The Return of the Soldier, West is not endorsing the melding of the female into the male. Rather, she is celebrating the power of the feminine spirit and places emphasis on the feminist ideal of regeneration rather than the patriarchal ideal of destruction: "That may seem an unlikely opinion for the young, independent, and feminist Rebecca West to endorse, as she surely does. What in fact she is celebrating is goodness, the creative, life-giving goodness that is independent of intellect, or of art as it is usually understood" (RS 5). Glendinning brings to light part of West's authentic definition of the feminine that is different from the male influence- regeneration and restoration. In response to the maledominated war society, West highlights the goodness of the feminine spirit and its ability to restore peace and order to an otherwise chaotic society. Rebecca West wrote in 1925 :

I am an old fashioned feminist. I believe in the sex-war... When those of our army whose voices are inclined to coo tell us that the day of sex antagonism is over and that henceforth we have only to advance hand in hand with the male I do not believe it ... - when [a new feminist] says in a speech that "women must learn to work with men." I disagree. I believe that women know how to work with men. But I believe that it is the rarest thing in the world for a man to know how to work with women without giving way to an inclination to savage his fellow workers of the protected sex.... The woman who forgets this, who does not realize that by reason of her sex she lives in a beleaguered city, is a fool who deserves to lose (as she certainly will) all the privileges that have been won for her by her more robustly-minded sister. ("Nagging")

West believed it naïve for women to think that they could merely enter into a world that had always been defined and was still being defined in male terms, and still be truly emancipated. West, like so many others, saw that real change had not occurred and could 
not occur unless men too decided that society required radical change. However, it would be unfair to claim that women had made no advances in society. On the contrary, in 1918 a battle in the war between the sexes was won in favor of the women's movement. It seemed as though women had, during the First World War, made a contribution to the "blood tax" through their participation in the war efforts.

Paying tribute to the mental and physical strain placed upon female noncombatants as they participated in the war effort as expressed by Rebecca West and Vera Brittain, Parliament granted some women the right to vote in $1918^{1}$ through the Representation of the People act of 1918, a gesture that Susan Kingsley Kent, in "The Politics of Sexual Difference: World War I and the Demise of British Feminism," describes as a welcome symbol of equality, but a gesture that "failed to enfranchise some five million out of eleven million adult women" because the right to vote was granted only to women over the age of thirty (232). As remuneration for their sacrifices regarding the war effort, the British government rewarded women with only partial voting rights. Prime Minister Herbert Asquith in August 1917 claimed:

Women cannot fight in the sense of going out with rifles and so forth, but ... they have aided in the most effective way in the prosecution of the war. What is more--and this is a point which makes special appeal to me - they say when war comes to an end. . when the process of industrial reconstruction has to be set on foot, have not the women a special claim to be heard on the many questions which will arise directly affecting their interest? ... I say quite frankly that I cannot deny that claim. (Fawcett 133)

Asquith could have been merely appeasing the women interested in voting rights to keep them from reorganizing a militant approach to the Suffrage movement which had lost some of its momentum during the war. Kent explains the government's decision to give some women the vote: 
Fear of women's power ... determined the terms under which they would be admitted to the franchise. While the Representation of the People Bill gave men the right to vote on the basis of residence premises, a grant of universal manhood suffrage, it restricted the women's vote to those who were householders or the wives of householders and who had attained the age of thirty. The age requirement ensured that women would not have the majority over men, whose numbers had been greatly reduced in the slaughter of war. (235-6)

After this bill was passed, with the acceptance of the National Union of Women's Suffrage Societies (NUWSS) founded in 1897, it was obvious that the movement had lost some of its momentum and ardor for its longstanding principle of attaining equal voting rights with men. Many women remained disenfranchised from the government, but the president of NUWSS, Millicent Garrett Fawcett, did not want to force the issue and argued that women did not want to "risk their prospects for partial success by standing out for more" (Fawcett 236). Fawcett's sentiments did not reflect only her cautious nature as a woman familiar with a patriarchal government. Rather, her words reflected a growing concern that the advancements women had made in society were by default only, that if the war had never happened, nothing would have ever changed, and if women were not careful, their hard-won, but limited rights would be taken away. While the Suffrage movement lost some of its political importance during the war, women still enjoyed advancement thanks to increased responsibility in the workplace. Sandra Gilbert explains in "Soldier's Heart: Literary Men, Literary Women, and the Great War," "as young men became increasingly alienated from their prewar selves, increasingly immured in the muck and blood of No Man's Land, women seemed to become, as if by some uncanny swing of history's pendulum, even more powerful" (425). While men sent to war often returned as "damaged males," women were excelling in their new public realm, working, earning, and advancing. Bonnie Kime Scott, in $A$ 
Companion to Modernist Literature and Culture, discusses the emergence of this New

Woman, a woman who was able to create her own financial independence by earning a living separate from that of her husband or father, and how this New Woman created a shift in European culture:

Traditional regulations of the gender system were undermined by sexual dissonances inspired by the New Woman, as variously discussed in emerging social sciences; the organized struggle for women's suffrage and birth control; by women's experiences of socialism, their participation in war, and entry into the culture and commerce of modernity. (536)

Women were making headway in a male-dominated culture simply by entering the public realm, but full social emancipation had not yet been realized.

After the First World War, there was a traditional backlash, pressuring women from the positions they maintained during the war to return to home and to the "better days" of pre-war Britain. This backlash came not just from society, but also seemed to come internally from some of the participants in the women's movement as well. As Kent explains:

The hostility toward women, the pressures on them to leave their jobs and return to the domestic sphere, were intense-and successful. By 1921, fewer women were 'gainfully employed,' according to the census of that year, than in 1911. In 1927, Oxford University limited the number of students permitted to attend the women's colleges. (239)

Even after some women gained the right to vote, many remained under the control of the patriarchy, leaving the suffrage movement with a great deal of work left to do. As Christabel Pankhurst, a leading feminist activist, and daughter of Emmeline S. Pankhurst, founder of the Women's Social and Political Union (WSPU) in 1903, wrote in 1924 "some of us hoped more from woman suffrage than is ever going to be accomplished" (Pressing Problems). Pankhurst's disappointment was not solely hers, but was felt by 
many who had fought for the rights of women and realized that it was not enough.

The focus of the movement shifted from the NUWSS, headed by Fawcett, to the National Union of Societies for Equal Citizenship (NUSEC) after 1918. This organization, under the leadership of Eleanor Rathbone, switched focus from voting rights for women to more specific female needs. After the First World War, some women believed that the struggle should resume as before with suffrage as the primary concern. However, others believed that since the right to vote had been granted, the specific needs of women should be addressed such as birth control, attention to pregnancy, and motherhood- these being actions and concerns in which only women participated. In her 1925 Presidential address, Rathbone stated:

At last we can stop looking at our problems through men's eyes and discussing them in men's phraseology. We can demand what we want for women, not because it is what men have got, but because it is what women need to fulfill the potentialities of their own natures and to adjust themselves to the circumstances of their own lives. (52)

Concerns such as family endowment for mothers, birth control, and protective legislation became the focus for the NUSEC as the "new feminist" agenda began to conflict with the old. Specifically, protective legislation had always been on the table of discussion for feminist activists since the $1870 \mathrm{~s}$, but at that time, most feminist activists opposed laws restricting the number of hours a woman could work. However, by the 1890 's, opinions had split more divisively, with "most trade union women supporting protection and many suffrage workers still opposing such laws" (Shanley 69). The new feminists believed that women had other important work to tend to inside of the home. As Kent explains, "new' feminist demands centered on the role of women in the home and the "occupation of motherhood - in which most women are at some time or another engaged, and which no 
man . . is capable of performing'(What is Feminism 195)" (Kent 240). This differs greatly from the feminists of the previous generation like Vera Brittain and Rebecca West who sought more egalitarian ends. Feminist Elizabeth Abbott raged against Rathbone:

New Feminism sees in maternity an eternal disability — just as antisuffragism saw eternal disability in other generations such as 'sex,' 'motherhood,' 'the home.' The equalitarian knows that it is not maternity in itself which is the disability; it is the horribly low and unequal status of woman, the everlasting conception of her as a means to an end instead of as an end in herself, that makes not only maternity but sometimes every hour of a woman's day a disability. (4)

This was a split in the movement, for old feminists viewed new feminists as actually antifeminist in their separate but equal mentality, and eventually, the new feminist ideals lost momentum.

No matter what the definition or agenda, the Suffrage movement remained a priority for many women before, during, and after the First World War, and well into World War II, for it was well known that just because women had the right to vote in 1928 , society was still not yet conducive to the female will; the norm was still maledefined, and that definition could not be so easily redefined by voting in a society that remained hostile.

While femininity tried to flourish, masculinity struggled with these major changes, and, as Bonnie Kime Scott explains in her essay "Modernism and Gender," "Masculinity suffered from the waning of empires, with their aura of masculine command, and the ravages visited upon a generation of men by the First World War" (536). Not only that, but they had to contend with women who in some way, enjoyed the war for its emancipating qualities, for it allowed women out of their homes and into society, giving them growing economic and political power. In their work, No Man's Land: The Place of the Woman Writer in the Twentieth Century, Sandra Gilbert and 
Susan Gubar explain this dual view of the war: "For despite the massive tragedy that the war constituted for an entire generation of young men—and for their grieving wives, mothers, daughters, and sisters - it also represented the first rupture with a socioeconomic history that heretofore denied most women chances at first-class jobs-and first-class pay" (2:276). While women enjoyed the benefits supplied by the war, the benefits also brought unavoidable guilt. Men, on the other hand, were very anxious about the emergence of this New Woman into modern society, but having come through a traumatic war, which now left many soldiers mentally and physically weak, there was not much they could do to reverse the cultural upheaval that was set into motion by the war. These anxieties were represented within the modernist texts being produced at this time. The works of D.H Lawrence and James Joyce exemplify the angst men felt towards women as they emerged into the public sphere during and after the First World War. As Sandra Gilbert and Susan Gubar state "For, as is so frequently the case in history of sex relations, men view the smallest female steps toward autonomy as threatening strides that will strip them of all authority. ..." (1:66). Not only in Great Britain, but across the continent, men felt great anxieties as women thrived amidst the devastation of the First World War. As women inundated the public sphere, their male counterparts resented their presence and their successes as men returning from the front returned damaged and traumatized. As Gilbert and Gubar write, "Women in the first third of the twentieth century were often empowered to imagine victory in the sexual battle not just because of their own new strength but also because of their antagonists' new weakness" (1: 90). The male population had been weakened not only in numbers, but also lost some power over their homes, wives, and families as women began to assert themselves more fully in 
society. The male resentments felt towards these emerging women are reflected in the literature produced during this time.

The First World War had a major impact on the modern aesthetic as well as upon the culture and the roles men and women played within the new society. It can be argued that the experimental methods employed by the modernists, such as the stream-of consciousness method, the reconfiguring of time, and their linguistic experimentation, were affected by the crisis of the war. The war created great anxieties over definitions of men and women, their gender roles, and their futures in society, and useful ways to express this anxiety and the new experiences of a changing culture were unavailable. Therefore, during the war crisis, and in large part because of it, modern experimentation and new forms of creativity were set into motion, and from that came modes of expression capable of describing a changing modern society.

In literary modernism, one tactic to show the battle between the sexes was to describe a breakdown in communication and language's inability to express thoughts to the "other." D. H. Lawrence uses this particular method to express his own anxieties about the gender question, for he portrays men and women in his novels as being unable to communicate with each other. The war plays into this idea very much, for it is through verbal battles, which in part can lead to physical violence, that the anxieties over the gender question are truly felt. Sandra Gilbert and Susan Gubar discuss this idea of battle between the sexes: "[W]ords. . . become not only weapons, but booty to be gained, spoil to be incinerated, or hostages to be massacred, suggesting that a major campaign in the battle between the sexes is the conflict over language and, specifically, over competing male and female claims to linguistic primacy"(1:228). The gender question for the 
modernists was answered through language, for the power to define was an ultimate prize that both sides of the issue desired.

D. $\mathrm{H}$, Lawrence, in his novel Women in Love, utilizes the breakdown of communication between men and women to portray his own anxieties about the New Woman in society and to express his desire for definition. Lawrence's Birkin defines what he believes is the true nature of women:

But it seemed to him, woman was always so horrible and clutching, she had such a lust for possession, a greed of self-importance in love. She wanted to have, to own, to control, to be dominant. Everything must refer back to her, to Woman, to Great Mother of everything, out of whom proceeded everything and to whom everything must finally be rendered up. (WL 200)

According to Birkin, the definition of Woman was a greedy and all-consuming Magna Mater, desiring every ounce of power she could grasp. This was the fear of many male modernists who saw women desiring to dominate everything. Helen Wussow explains the struggle for definition in Lawrence's work in The Nightmare of History: The Fictions of Virginia Woolf and D.H. Lawrence: " In Women in Love, words are a means to selfidentity, the on-going struggle to communicate with the other yet be separate from it. ... Birkin's arguments with Ursula are quests for definition. Dialogic battles between characters are frequently accompanied by actual physical violence" $(90)$.

Language is a weapon used to fight the battle between the sexes. Turning to Women in Love, one is inundated with examples of how Lawrence uses language as both a means of definition, as a weapon, and as a proverbial shield to block the violence that ensues between men and women as communication breaks down. A conversation between Hermione and Birkin becomes violent, for the breakdown in communication causes her to launch a physical attack upon him: “'If,' said Hermione at last, 'we could 
only realize, that in spirit we are all one, all equal spirit, all brothers there-the rest wouldn't matter, there would be no more of this carping and envy and this struggle for power, which destroys, only destroys"” (WL 103). Birkin strongly disagrees with Hermione about the nature of this equality arguing the otherness of people, and this causes her to become very angry. Birkin then feels guilty for hurting her so, and looking for her, finds her in her room writing letters. He says nothing, but sits and begins reading while she is too distracted to continue writing her letters. His linguistic activity is in no way hindered at this moment while Hermione is now blocked from continuing hers. Even the act of reading becomes hostile as Birkin utilizes a book as a barrier to block Hermione's attempt at communication. Frustrated, she then launches a physical attack by hitting him with a ball of lapis lazuli. Birkin utilizes his shield, this time not to ignore her, but rather to protect himself from the violent act that ensues after communication breaks down: ". . the blow came down, almost breaking his neck, and shattering his heart. ..." Hermione believes that "she had only hit him, as any woman might do, because he tortured her" $(W L 106)$. The torture is linguistic in nature. The characters' inability to express themselves through language and have that expression understood seems impossible. The frustration from this causes violence, and thus the battle continues, a battle for meaning, a battle for self-expression, and a battle for definition.

Lawrence also provides a vision of the New Woman in Women in Love through the character of Gudrun Brangwen. Gudrun is greatly contrasted with her sister, Ursula, for Gudrun maintains her independence and individuality from her lover, Gerald Crich. Ursula and Gudrun become two very different women. While both sisters grow up with the same opportunities, Ursula escapes the lower social realm by marrying Birkin while 
Gudrun remains an artist, independent and free. According to Kate Millett in Sexual Politics, "Ursula escapes. . . by accepting Birkin as her husband and leader. For while she is merely an underpaid schoolteacher, Birkin is a superintendent, owns three houses, has private income, servants, and an automobile. Gudrun, unmarried, continues to practice her art, a freelance and "Glucksritter"' (268). Gudrun remains single, even though Gerald would marry her if she would have him. But Gudrun knows that Gerald wants to consume her, and she pulls away from him. Ursula allows herself to be consumed by Birkin. Gudrun makes the decision for herself to leave Gerald and does not allow him to stop her physically or verbally:

"I have been thinking, Gerald," she said, with an insulting nonchalance, "that I shall not go back to England."

"Oh," he said. "Where will you go then?"

But she ignored his question. She had her own logical statement to make, and it must be made as she had thought it.

"I can't see the use of us going back," she continued. "It is over between me and you-" $(W L 461)$

Gudrun's matter of fact tone and refusal to be questioned by Gerald sets her apart from her sister, who seeks counsel from her husband on when they can leave and where they shall go; Gudrun makes decisions on her own. While she does take the time to inform Gerald of her plans to leave, she dismisses his questions. Gudrun's rejection of Gerald ultimately leads to physical violence as they attack each other, and Gerald almost succeeds in killing Gudrun:

He took the throat of Gudrun between his hands, that were hard and indomitably powerful. And her throat was beautifully, so beautifully soft. Save that, within, he could feel the slippery chords of her life. And this he crushed, this he could crush. What bliss! Oh what bliss at last, what satisfaction at last! The pure zest of satisfaction filled his soul. He was watching the unconsciousness come into her swollen face, watching her eyes roll back. How ugly she was! (WL 471) 
But Gerald lets go, and Gudrun falls to her knees gasping for breath. Gerald is disgusted with himself, and he walks off into the snow and ultimately to his death. As Gerald walks, he contemplates the likelihood of being murdered and becomes resigned to the fact that he will be murdered: "Somebody was going to murder him. He had a great dread of being murdered. ... Yet why be afraid. It was bound to happen. To be murdered! ... He was bound to be murdered, he could see it. This was the moment when the death was uplifted, and there was no escape.... [He] knew he was murdered. ..."(WL 473). Finally, Gerald's fear of death comes true: "But he wandered on unconsciously, till he slipped and fell down, and as he fell something broke in his soul, and immediately he went to sleep" (WL 474). Gudrun did not kill Gerald with her own hands, but her rejection of him sent him down a path of destruction. Gudrun's unwillingness to succumb to Gerald's desires becomes his killer.

Like Lawrence, other modernists were greatly affected by the gender question as women moved from the private sphere of the home into the public sphere of the work place in a shifting society devastated by the atrocities of war. These modernists used their writings to express their own anxieties about these changes. James Joyce's Ulysses depicts a particular scene in the "Circe" episode where an impotent and damaged Bloom dresses in female clothing only to strip from that degraded state to return to his more powerful male form, as if to be reborn into his rightful power position in society. Gilbert and Gubar discuss that while Joyce was a noncombatant during the war, he still had opinions about the repercussions of that event, especially where women were concerned. They claim that "even an apparently alienated noncombatant like Joyce would have seen . .. the need for righting the wartime sexual wrongs by bringing the traditional (male) hero 
home to his proper manhood"(2:334). Bloom's cross-dressing episode turns "male" into "victim," and Bloom is abused by a manly woman, forced to become a woman himself. Bella Cohen, the whorehouse mistress, orders Bloom to become "wigged, singed, perfumesprayed, ricepowdered, with smoothshaven armpits" like the other whores of the house, while Bella becomes Bello, transforming into a man as Bloom transforms into a woman ( $U$ 15:2972-73). As Gilbert and Gubar explain, "Bello becomes a grotesque parody of masculinized female mastery, hunting and beating the trembling masochistic Bloom" (2: 332). Bello proceeds to taunt, abuse, and order Bloom around, humiliating him as he crawls around in his new identity. As Suzette Henke describes in James Joyce and the Politics of Desire: "It is clear from the role reversals in 'Circe' that, in terms of cultural representation, female gender confers parodic marginality. Woman seems destined to play the part of l'autre, alienated other in the specular projections of the male libidinal imagination" (115). Bloom is degraded in his female clothing because being a woman is degrading. Assuming his female position, Bloom is powerless over the woman turned man; Bella/Bello now possesses the power of the patriarchy of which Bloom is now a subject. Henke goes on to explain this scene as a reflection of the male anxieties experienced in modern society:

Even the comedy of language cannot alter the binary codes of gender or the deeply embedded sex-roles inscribed in societal consciousness. The text seems to invoke the pervasive cultural fear that woman, granted phallic authority, would persecute her mate with unbridled ferocity; and that man, bereft of the kind of patriarchal power that buttresses an illusory sense of dominance and mastery, would sink helplessly into sexual degradation. (116)

Bloom does confess however to have adorned himself in his wife's clothing before: "I tried her things on only twice" ( $U$ 15:2987). In this particular section, there are also specific comments on Molly Bloom's dominating character, and how Bloom not only 
wore her garments, but also washed them as well: "When we were hard up I washed them to save the laundry bill" ( $U$ 15:2988). Bella/Bello's response to this: "Little jobs that make mother pleased, eh?" (U 15:2990). Molly is the dominant partner in this relationship, reducing Bloom to an impotent, feminized washerwoman. Bloom, however, throws off this reduction and returns to his maleness. Joyce is interested in returning men to their place in society, reclaiming patriarchal power from the emerging New Woman.

The anxieties expressed by both D.H. Lawrence and James Joyce within their literary works reflect a larger thought process influencing society at large. The battle at the front was affecting the battle between the sexes, and for the modernists, their battle was being fought on the front lines of linguistic change. The power of description and definition was something each side of the woman question wanted, and while the male modernists had the upper hand, possessing inherent patriarchal power, women were making societal strides forward, attempting to influence a culture that had been created from the devastation of war. Through their literary works, the idea of gender was laid out very clearly by the modernists who felt great anxiety about the changing world. The male modernists faced a New Woman, fearing that her ultimate goal was to devour them, while the women feared being pushed back into the private sphere. This was a battle that mimicked the war being fought across the European continent. For the modernists, war was not only an international crisis, but a private one. Power structures in society were acted out within the home, and all rules, both public and private, were now subject to change. 


\section{French Female Suffrage:}

"A task that requires the genius of Napoleon and the heart of Jesus"-George Sand

The struggle for French suffrage was brewing at the same time as British suffrage began, but it was not always as evident. Actually, French Suffrage for women was fraught with many barriers, as popular social opinion was unwilling to view women as anything other than possessions handed from father to husband. After the French Revolution, women's rights activists argued for the full citizenship of women but were always rejected. The popular "fear" was that women's social and political freedom would exacerbate the moral decay rampant in society. The idea of la femme libre put forth by Prosper Enfanatin was viewed "not as a general formula for freedom but as an invitation to adultery for married women" (Offen, Ernest Legouvé 473). Due to the fear of being viewed as a person who supports the moral decay of women in French society, women like George Sand and Marie d' Agoult shied away from supporting la femme libre (Offen, Ernest Legouvé 464).

Before and after the French Revolution, many observers decided that because of women's discontent, the order of the family was in disarray and therefore, society was in disarray. Women's rights opponents believed that women should be satisfied with their lot in society instead of fighting for change. In 1804, Napoleon took on this social issue in his Civil Code where he upheld traditional roles of men/husbands as well as the traditional restrictions upon women/wives. The code continued the restrictions upon married women's rights pertaining to their personal property, person, and offspring, and argued for the superiority of religiously-directed/controlled education of women for moral reasons. A religious educational system was refuted in the 1880 's as educational 
reform took a more secular approach. Here is the culmination of the most important feminist issues: financial and educational concerns, as well as parental rights. These three issues were fought over for decades as women sought to redefine their positions in society and in the home and as men fought to maintain their controlling interests in society and in the home.

French activists were well aware of the events taking place in Great Britain in regards to social change. However, in 1840 , while French female suffrage was an issue, universal male suffrage took center stage as men worked to earn the right to vote for all male citizens regardless of class and education. Universal male suffrage had been an issue since 1792, but due to social turmoil was not a powerful social reality until 1848 . Many women resented universal male suffrage, for it allowed all men the right to vote regardless of their intellectual abilities while many women of great intellect were still unable to vote. This upheld the idea that all men, even the lower-classed, were more valuable within society than even the highest-classed lady.

For feminist activists, with the revolution of 1848 , fresh hope arose with the implementation of a new government. French suffragettes appealed to the new, (unorganized) Provisional government, as every "special interest" group did, to take the rights of women seriously, for the Provisional government began with the best intentions to do what was right for all people in France. The hope was that with the new government, there might be new views on the woman question being debated in France. Many female writers of the time were involved in expressing opinions over what was happening politically and socially during and after the Revolution of 1848. Marie d'Agoult (also known as Daniel Stern), George Sand, Delphine Gay de Girardin, and 
Hortense Allart stayed abreast of the changes during this important time. According to Daniel Stern's History of the Revolution of 1848, "The Provisional Government was indeed worthy of the nation because it was entirely motivated by the sincere desire to adhere to the national will" (385). Many French feminists hoped that there was room for women in the public sphere, but others believed that political power should be the end result of the struggle, not the starting point. Daniel Stern wrote tirelessly of the need for women to act rationally rather than passionately so as not to alienate the powerful men who were in a position to help or hinder their cause at whim:

Instead of . . . addressing simply and modestly the questions regarding the education of women of all classes, the careers that could be opened to women, the wages of all working-class women, the authority of the mother in the family, the dignity of the wife ... instead of progressing step by step with prudence as public opinion becomes more favorable, [feminists] acted very impoliticly; they noisily started political clubs that quickly became laughable. (190)

Stern's concern was that public opinion of a women's movement was so low that women had to maintain a modicum of tradition and manners so as not to alienate themselves from the majority. This is a sentiment that continued throughout the French suffrage movement and at many times caused a split within feminist activist groups who differed on how women should act or be viewed within the home and within society. It was thought by Stern and others that the popular revolution and thus the new government would naturally lend itself to equality of the sexes, and therefore to push the suffrage agenda in any way other than a delicate manner would be to alienate and ruin any chance of female political power.

George Sand, who was interested in the principles of equality and social justice, wrote in an 1848 letter that "The Provisional Government is composed of men who are excellent for the most part, all a little inadequate for a task that requires the genius of 
Napoleon and the heart of Jesus" (8:330). By April, however, she wrote to her son, "Men are false, ambitious, vain, egotistical, and the best of them is not worth the devil... The leaders of the true social idea are hardly more enlightened than the men they combat, and they play the game too much for their own benefit" (8:418). Sand believed that the ideals of the revolution were pure and not to blame for the position of women in society; rather, the men who controlled the government distorted the spirit of the revolution and merely acted in their own best interests: "the flawed characters of men were the sole source of disaster"(8:330). However, Sand, like many others, did not believe that women were ready for political power, and openly wrote that while some day women would be ready for this change, that day was not near because of women's subordinate and dependent position in marriage. For even in the private sphere, the domain designated for women, women still had very little power. Sand urged the new government to revisit and revise the existing laws concerning women, marriage, and families claiming that it would not hurt marriage but rather "if men and women are held to the same standard of commitment and responsibility in the family, immorality as well as abuse would decline" (8:402-3). For Sand, social change could not take place unless women were able to exert some sort of will within their very own homes. Sand urged feminists to rally for equality in more nonpolitical settings, for if they continue to push their agenda publicly, where it was falling on deaf and even hostile ears, then "they will only alienate public opinion by demanding political equality because the public equates political equality with 'freedom of passion"" or promiscuity (Walton 1014).

Delphine Gay de Girardin, and Hortense Allart, like Sand, hoped for a collection of new politicians who embodied the spirit of change brought about by the revolution, but 
were ultimately disappointed. According to Whitney Walton in "Writing the 1848 Revolution: Politics, Gender, and Feminism in the Works of French Women of Letters," Girardin felt betrayed by the leaders of the new republic: "The leaders of the republic had not understood what a republic should be; ... instead of working hard for a new government of simplicity and honesty, they had maintained rituals and relations that were no different from practices under the monarchy. For their personal advancement they had exploited the people who fought on the barricades" (1011). By June of 1848, dreams of social change in favor of women were quickly squelched as women realized that the men who had attained power were no different from their predecessors in asserting patriarchal domination. Women's equality would remain an ideal rather than a reality.

Opportunity for a quality education has always been a necessity for advancement and equality, and in the1800's in France, the education of women was yet another battle ground in the war between the sexes. On December $21^{\text {st }}, 1880$, the Sée law, named after its author Camille Sée, was implemented in order to:

establish a state system of mass, secular public instruction in France--free and compulsory on the elementary level and open (for a fee) on the basis of social standing and/or merit on the secondary level. All these measures sought, in the name of republican progress, to remove formal instruction of the young from the control of the Catholic Church. (Offen, The Second Sex 254)

Sée believed that the women of a nation were of the utmost importance, for they were the instructors of the nation's children. Therefore, in order to have well informed, welleducated children, those children needed well-informed, well-educated mothers. According to Karen Offen in "The Second Sex and the Baccalaureate in Republican France, 1880-1924," the mère-éducatrice argument "emphasized the practical utility of literacy, learning, and intellectual activity for women, and underscored its vital 
importance for their successful performance as companionate wives and mothers, [and this idea became] an article of faith among the republican founders of girls' lycées"(255). Many argued that the education of women should be improved, but these improvements were not meant to improve her individuality or success in the public sphere. Rather, these educational improvements were meant to make her a better companion to her husband and a better caregiver to her children. Offen explains that the goal of the educational reforms was to "develop the intellects of the women of the new political elite- women destined to marry republican men, to build republican homes, and to raise citizens for the republican nation" and this idea of female education was very popular and expanded quickly (252). These changes were not to benefit a woman's personal identity, but rather to make her fit to serve her societal roles of wife and mother:

If nineteenth century men had conceded literacy to women, they had not conceded the right of wholly free inquiry or activity - free, that is, from the mediating influence of male authorities, whether those associated with organized religion or those identified with science, especially physicians, whose contributions to the new secular morality of the Republic cannot be overestimated. (256)

It was believed by many in the sciences that "too much brainwork during adolescence would endanger the reproductive capabilities of the future mothers of France," and so they had to be monitored in their educational endeavors so that this danger could be avoided (Offen, The Second Sex 259). However, it is important that there were any discussions at all over improving the education of girls and women in France at this time, even if those discussions centered on how to make women more fitting to their societal roles. Access to a legitimate education, something that could even come close to rivaling male education, was a large advancement for the women of France regardless of it aims, namely marriage and motherhood. Without education, women stood little chance of ever 
entering the public sphere. The battle for education had begun in France.

An important figure to consider when addressing the history of the women's movement in France, especially in regard to education, is Ernest Legouvé (1807-1903). Legouvé wrote and lectured on the woman question, proposing reforms of both law and society in general in order to elevate the perception of women's status in society. As a dramatist, essayist, and member of the Académie Française, Legouvé presented many lectures on the topic of women at the Collège de France in Paris in 1848 at the invitation of his friend, Jean Reynaud, who had been appointed under-secretary to the minister, Hippolyte Carnot. Hundreds of Parisians, both male and female, attended these lectures, which discussed the current woman question in French society.

In his lectures, and then in his work Histoire morale des femmes (1849), Legouvé proposed civil and social reforms that spoke to the importance of appreciating woman's place in society and in the home. Popularizing the phrase "equality in difference," Legouvé set out to better a woman's standing in French society, celebrating what makes women women, in his opinion, and what sets them apart from men in society. Legouvé was not interested in seeing women assimilated into male society, but rather in making it easier for a woman to be the individual (in her family) she could be. In proposing his reform program, Legouvé pointed out inequalities in all aspects of women's lives including single life, marriage, education, labor, motherhood, and divorce. It is important to stress that Legouvé's goals were not feminist but still addressed and aided many of the important feminist issues of the time.

Legouvé was careful when speaking about his reforms, for it was not in his best interests, or the interests of his cause, to alienate his male audience members. According 
to Karen Offen in "Ernest Legouvé and the Doctrine of 'Equality in Difference' for Women: A Case Study of Male Feminism in Nineteenth-Century French Thought," Legouvé addressed the woman question in a way that would not offend his male audience, an audience that was necessary to bring his reforms to fruition:

When Legouvé began his lectures, universal manhood suffrage had just been granted by the Second Republic. The Frenchmen in his audience were thus in possession of full political rights without property qualifications--the first men on the European continent to be so empowered. In that unsettled revolutionary spring of 1848 , Legouvé was addressing the very audience that would ultimately endorse or reject all measures to reform women's condition that required a political solution. (467)

Therefore, Legouvé tempered his discussions of women by centering all ideas on concern for the family and the importance of strong familial relationships. Using this type of language would help relieve some of the many anxieties the public possessed towards women's changing roles in society. Again, it was the popular sentiment that if women were allowed more freedom in society, the family structure would cease to exist and society would crumble as a result. To avoid being associated with the destruction of society, Legouvé avoided going to one extreme or the other in regard to the woman question, and he tried to remain in the middle, recognizing that it was necessary to have the cooperation of the opposition in order to get any changes implemented. As Karen Offen explains:

Legouvé's goal was to redress the balance of power between men and women with a restructured family setting, by arguing from the very centrality of women's vital biological and social role as mothers...his goal was not solely to improve the position of woman as women but to achieve a more sweeping goal: the rehabilitation of the entire society through transformation of the family structure. (Offen, Ernest Legouvé 466)

In his work, Histoire morales des femmes, Legouvé proposed legal reforms for different groups of women pertaining to several aspects of a woman's life. For unmarried women, 
or young girls, he proposed an overhaul of the educational system. He also argued for the rights of an unmarried woman to have a say in the creation of her marriage contract. For married women, Legouvé felt that it was necessary for a woman to have rights to her property, to her person, and to her children. According to Offen, "Legouvé made women's biosocial function into an argument for the major legal and educational reforms he advocated ...Legouvé insisted that men give women more actual power at law in matters pertaining to their own children, a power so severely restricted in Napoleon's Civil Code" (Offen, Ernest Legouvé 471). As Legouvé wrote in his Histoire morale des femmes, "Maternity is a career, at once public and private; marriage is a profession with all its expectations and occupations" (qtd. in Offen 475). According to Legouvé, since women spent more time with their own children, they would be better authorities in matters pertaining to their children's welfare, including how they were educated. He also wanted women to have the right to bring paternity suits against fathers, an idea that strongly contradicts the Napoleonic Civil Code. And finally, he felt it very important to have civil divorces, a reform that went against the Church and many republicans and traditionalists.

As a favored phrase, Legouvé's slogan "equality in difference" helped define a type of feminism known as familial feminism. This feminist position upheld the idea that men and women shared a complementary relationship where one compensated for the other's weaknesses, and that while men and women needed to be equally respected and protected in society, they were in fact destined to fulfill very different roles. Offen explains Legouvé's "equality in difference":

Women and men were destined to play separate and distinct, albeit complementary, roles in life, therefore each sex should be educated that its 
members might also advantageously fill their designated function. Man's role was a public one, to be exercised in the forum, woman's role was a private one, to be exercised in the foyer or household, under a man's protection. (Offen, The Second Sex 257)

However, not everyone found Legouvé's ideas appealing or advantageous for women in society. Many feminist activist groups, such as Individualist feminists, believed that "equality in difference" thinking was dangerous, for it predestines women to fulfill roles that they themselves did not create. There is a radical difference between Familial feminism and Individualist feminism:

Individualist feminism sought equality of opportunity for the individual, irrespective of sex, familial considerations, or national concerns. . . . [It also] opposed the sexual division of labor, repudiated all concepts of woman's special nature, and insisted on an end to sexism, gender distinctions, and class distinctions as well. (Offen, Depopulation 654)

For the Individualist feminist, "equality in difference" was unacceptable, for this line of thinking assumes that there are in fact inherent differences in the way men and women are supposed to live in society, and these differences cannot be denied. While Individualist feminism looks more like the feminism we think of today, in late nineteenth and early twentieth century France, it was considered radical. For it was the belief of the majority that a woman's primary role in French society (as in many other societies during this time) was that of the mother within the private sphere of the home, and to remove her from that "sacred" role would be damning to the nation. This was the case for generations, and when reforms began to take place, and women began to emerge into the public sphere, there was a backlash against women's newer public selves. At the fin-desiècle, there was a population crisis, where deaths outnumbered births in France; while the populations of other European countries were steady, France seemed to be shrinking. In her work Feminism and Motherhood in Western Europe 1890-1970, Ann Allen 
discusses the implementation of a birth strike in France as feminists argued that women should not be expected to reproduce within a state that does not acknowledge their validity in society:

The "birth-strike" ... was first advocated by the French Neo-Malthusians, who since the 1890s had urged workers to refuse to produce more human material to be consumed by industry and war. Nelly Roussel gave their message a feminist twist. Women, she swore in 1903, would no longer produce children for a society that offered them nothing but scorn and degradation. (107)

While some women engaged in this birth strike, that is not the primary issue here. What is most important is the idea that women were discontent with these socially prescribed roles and were seeking ways within society to rectify the injustices they saw in their lives. Procreation and motherhood were such large parts of women's lives, and they had very little control over either. Women increasingly sought ways to possess power over their own bodies, especially where reproduction was concerned.

Countries like Germany and England eventually experienced population declines, and blamed the women of their countries for this, but France was the first to witness such a decline and actually had the farthest to fall, after having been the more populous country. A look at the population numbers taken during the censuses shows a slight increase in France while England and Germany experienced a boom, which in turn is interpreted as a decrease for France in regard to military strength. Between 1850 and 1910, the French population increased by 3.4 million while Germany's population increased by 25 million, and England's population grew by almost half from 17.9 million to 36 million (Offen, Depopulation Graph 1). Even though it seems noble that feminism was taken up in familial terms (at least some changes were being considered), it is important to recognize that this argument had more support from the majority primarily 
due to its focus on national strength; the popular line of thinking was that a strong family unit mimics a strong social structure which mimics a strong military apparatus. The military might of the nation depended upon the procreation and the rearing of future citizens/soldiers (or cannon fodder as many reformers argued).

"Motherhood" became a matter of national concern when the state understood that it was through the perpetuation of its people, growth of its population, and the rearing of citizens loyal to the state that national power could continue. Therefore, procreation, birth, and "motherhood" became important political matters. As Yolanda Astarita Patterson comments in "Simone de Beauvoir and the Demystification of Motherhood," "Once the state began to look upon children as future citizens and soldiers, their care and nurturing became a matter of general interest to men and women alike"(88). Patterson explains that, "For more than sixty years of the twentieth century, Western society conditioned women to become wives and mothers and made those who rejected those roles feel somehow inadequate and incomplete"(88). A woman's decision not to bear children or even her lack of desire to do so was used to make her feel guilty; ostensibly, she was allowing her nation to fall into oblivion by her lack of concern for the state's population. Elisabeth Badinter discusses the "use" of motherhood in her work "Maternal Indifference" claiming that the woman as "natural nurturer" is a social construction that has no basis in historical reference. The "natural nurturer" characteristic popularly attributed to women is a creation that justifies keeping women in the private sphere tending to future citizen/soldiers . Badinter explains that in the $16^{\text {th }}$ and $17^{\text {th }}$ centuries, French women, according to their social station, had very little to do with their offspring. A wet nurse, for example, would nurse the baby, for mothers would claim that 
nursing "bores me and I have better things to do"'(157). Then the child would be handed off to a tutor or governess, and finally sent away when he or she reached school age.

During this time, a child would ultimately spend very little time with the parents.

Badinter explains:

The young infant, an annoyance to his parents, was placed in the hands of a hired nurse until his weaning. But the mother did not stop there, for she rejected children of all ages. Children interfered not only with the mother's conjugal life ${ }^{2}$ but also with her amusements. To busy oneself with a child was neither enjoyable nor chic. (161)

Women of a certain class were able to make a choice as to how much time they spent with their offspring. This idea, argues Badinter, discounts the idea of the "natural nurturer" stereotype applied to all women and all mothers. Of course, women of lower classes could not afford to employ a wet nurse or send children to boarding schools, but when women were able to shift the responsibilities of motherhood on someone else, they did so in great numbers and with no reservations; in fact, it was in vogue and socially acceptable to do so.

In the late $19^{\text {th }}$ and early $20^{\text {th }}$ centuries, many opposing arguments erupted as to the causes of the population decline. Some blamed birth control, arguing that women should have zero access to anything that would prevent pregnancy. A woman's use of contraception was viewed by many as "a woman's ultimate act of civil disobedience" (Offen, Depopulation 671). Adolph Pinard, a French obstetrician, even went so far as to claim that "women's contraceptive practices [account] for 80 percent of the benign tumors observed in women's reproductive organs after their surgical removal" (Offen, Depopulation 670). Popular anxiety over women taking charge of procreation, purportedly woman's principle function, was a primary reason why women remained 
disenfranchised in society. According to Ursula Tidd in Simone de Beauvoir, Gender and Testimony, "For most of the first half of the twentieth century ... a pronatalist policy was pursued in France, despite the efforts of the suffragists and the activities of movements such as the Neo-Malthusians, who advocated birth control as a means to improve the lot of the working class, rather than out of concern for women's autonomy" (33-4). The only way that women were going to make any headway in society and further their position was to conform to the popular idea that women were born to be mothers and that this was their most important role. And while these separate but equal roles must be played out within the private home as well as in public, at least the role of mother was held in some esteem and therefore required that more attention be paid to the education of the women who were to raise the future citizens.

In these early years of the cause, women did not obtain any rights or privileges that were outside the scope of the family. She was defined solely in biological and familial terms. She was viewed not as inferior but rather, just different, and those differences made it necessary that "a woman's life was to be centered entirely on the household, where her role was to influence children, especially sons, to become morally exemplary adults" (Offen, Depopulation 666). It was when a woman's ambitions focused on educational, financial, and political endeavors that the conservatives began to complain. Even though there were many who did support the advancement of women during these times, their ultimate goals "were not calculated to deliver French women from male control; rather, they would have effectively ensured women's material dependence on the good will of men" (Offen, Depopulation 653). They saw the usefulness of women in society and made sure that she was used in the most productive 
way, namely as the mother of a future citizen. Her education and well-being were important because of her role as a mother.

Despite the long battle for women to gain rights in French society, French women were not given the right to vote until 1944 after both world wars, and long after British women were given this right as well. But how much did the right to vote actually change the lives of women in society?

\section{Virginia Woolf and Simone de Beauvoir}

In the past, the battle of the sexes was futile when everyone agreed that there were inherent differences between men and women that made the binary gender system justifiable. Only when gender no longer plays a role in defining a person can change occur. During the struggle for equality, the biggest barrier facing women from either country was that of gender, i.e. that which makes women women and thus different from men. These differences, rooted in biology, were the validating source for suffrage opponents, who believed that if women were allowed public power, the home, the family, and thus the nation would crumble. Biology was the determining factor in denying women access to a proper education, and thus professional success and financial independence. It was thought that if women had access to these social necessities, there would be no one to tend to the private sphere or submit to male interests. Therefore, restrictions were placed upon women so that they were unable to realize their social selves. These restrictions were not only indicative of life in France and Great Britain. On the contrary, all across the European continent in countries like Germany and Italy, as well as across the ocean in the United States, and even across time looking back at the 
great warrior nation of Sparta, women were viewed as providers of citizens/soldiers, giving children to the state. The population growth of a state was an integral part of not only a nation's perceived strength, but also a realistic measure of strength as military power was decided by the number of bodies in the armed forces. Because she is a woman, who has the reproductive organs to carry and bear children, woman was kept from wielding public power.

Especially after the First World War, as so few men returned from the battlefront, women were kept or pushed back into domesticity. So much of the suffrage movement across Europe focused on women's voting rights, but how could women, even voting women, exercise any power in a society that was designed to uphold patriarchal values and priorities? How could she change a system while participating in that very system? This is the dilemma that Virginia Woolf and Simone de Beauvoir take up in their writings as the First World War and then World War II shattered their respective countries. Through their fictional characters, as well as through their polemical writings and memoirs, Woolf and Beauvoir comment on the gender issue, depicting the traditional woman as compliant, almost an accomplice in the maintenance of the status-quo society. Through many of these fictional depictions they are creating an inverted comment on the problems of society, using character flaws to highlight what changes need to be made. Woolf's Clarissa Dalloway, for example, is an exemplary lady of the house, participating in her pre-ordained role in society as the proper wife, mother, and hostess. However, as the reader is allowed insight into Clarissa's inner life, we find out that she is not as complicit as she seems to be, and secretly fantasizes about a different life, a different world, a different society. So too in Beauvoir's fictional world, we see women living a 
traditional life and yet, as Patterson explains, "Her fictional works contain a vast spectrum of mother-child relationships which become more nuanced as the author matures, and which move from a sense of anger and outrage to one bordering on pity for victims of a system not of their making" (Patterson 90). This system "not of their making" is an idea that both Woolf and Beauvoir come to terms with in their life and works, and they begin to draw upon a new idea, one that releases society from the confines of a gendered self. However, before a new definition can emerge, the old one must be defined. Instead of defining the self against the other as in the male/norm, female/other tradition, Woolf and Beauvoir define women first by creating the image of the traditional lady of the House (as well as the master of the house) as viewed in both Great Britain and France. Once this image has been created, both writers critique the traditional woman's place in society and in this critique, they then begin work on something new- a new definition of the self, outside of binary gender distinctions. 


\section{Notes}

${ }^{1}$ It was not until 1928 that all women aged 21 years would be allowed to vote as dictated by the Representation of the People Act of 1928.

${ }^{2}$ Badinter explains that fathers were "forbidden" to have sexual relations with their wives if they nursed for fear that the sperm spoiled the milk and would thus harm the baby. This seemed to encourage men to seek sexual gratification extra-martially or to encourage women to hand over their children to a wet nurse. 


\section{CHAPTER TWO: THE LADY OF THE HOUSE IN FRENCH AND BRITISH CULTURES}

Before one can define what the "New Woman" was or needed to be after the First World War and during World War II, one must define what she was before. The works of Virginia Woolf and Simone de Beauvoir provide detailed images of traditional women during the late nineteenth and early twentieth centuries in France and Great Britain. These images are particularly useful when trying to imagine the necessity of a new definition of "woman" as the First World War and then World War II swept across these two countries and changed how human beings (inter)acted in the world. The traditional woman as she was viewed in both French and British culture is depicted as one of the female personas in the works of Simone de Beauvoir and Virginia Woolf. Specifically, the image of the wife/mother viewed from several different lenses is useful in fleshing out the definition of what a traditional woman was during the first half of the Twentieth Century in Great Britain and France. The images of women in these "gendered" roles lends to the argument that the oppression of the "second sex" is based on the fallacy that being "woman" has truth in society in regard to female employment, motherhood and childcare, class-based access to birth control, female education, and political powerlessness.

Using Woolf, Beauvoir, and their characters, it is possible to create a picture of a woman and the changes she needed to undergo in order to fit into a new world that was created in the devastation and aftermath of war and death, leading to 
(re)(de)constructionof gendered roles. Virginia Woolf's fictional works Mrs. Dalloway and To the Lighthouse, as well as her polemical works, A Room of One's Own and Three Guineas, and Simone de Beauvoir's When Things of the Spirit Come First and The Woman Destroyed, as well as her polemical treatise, The Second Sex provide image upon image of women during the world wars as the female sex was emerging, against many obstacles, into the public sphere traditionally denied them.

The works produced by both Woolf and Beauvoir as the World Wars were being fought across the European landscape, and as women sought to redefine themselves uniquely, articulate a gender crisis. As Woolf discusses in A Room of One's Own, "[Women] had no tradition behind them, or one so short and partial that it was of little help. For we think back through our mothers if we are women. It is useless to go to the great men writers for help, however much one may go to them for pleasure" (AROO 79). This passage connects Woolf and Beauvoir, for each considers the cyclical relationship of mothers and daughters and how both have had to contend with a society not of their making and designed without their best interests in mind. As Woolf states, "we think back through our mothers," but the mothers were situated in the same oppressive society dominated by patriarchal concerns, and therefore, female history is defined, in many cases, by oppression (AROO 76).

Virginia Woolf and Simone de Beauvoir were troubled by the inequities facing women in society, not just professionally, educationally, and economically, but biologically as well. Each woman wrote in fiction, polemical prose, and autobiography about the plight of women, and argued for divergent thinking not just within social practices, but within the idea of a "female gender" as well. Previous ideas about who a 
woman was and what she was (un)able to achieve in society were being debunked as women moved out of the home and into the larger world, fighting for their rights to work, learn and live as independent beings capable of creating their own definitions based on personal experience rather than on anatomy. However, as we saw in the first chapter, women were not powerful enough to create actual change in a society that was already designed to defend patriarchal interests. At some point in time, women had the right to vote, but how was that useful when they had to vote in a system that was not constructed with women's interests in mind? Beauvoir in The Second Sex discusses the reasons behind the failure of women to achieve full emancipation in society even though they were making progress both politically and financially:

The reason for this is that women lack concrete means for organizing themselves into a unit which can stand face to face with the correlative unit. They have no past, no history, no religion of their own; and they have no such solidarity of work and interest as that of the proletariat.... They lived dispersed among the males, attached through residence, housework, economic condition, and social standing to certain men-fathers and husbands-more firmly than they are to women. (xxv)

The lack of female history and stability in culture is an issue Woolf also takes up in Three Guineas. In particular, Beauvoir's last comment reminds one of Woolf's contempt for women being defined as the daughters of educated men in Three Guineas:

Our ideology is still so inveterately anthropocentric that it has been necessary to coin this clumsy term - educated man's daughter - to describe the class whose fathers have been educated at public schools and universities. Obviously, if the term "bourgeois" fits her brother, it is grossly incorrect to use it of one who differs so profoundly in the two prime characteristics of the bourgeoisie-capital and environment. (146)

In Mrs. Dalloway, Clarissa Dalloway recognizes that she is losing her identity as she melds into that of her husband: "She had the oddest sense of being herself invisible, unseen; unknown; there being no more marrying, no more having of children now, but 
only this astonishing and rather solemn progress with rest of them, up Bond Street, this being Mrs. Dalloway; not even Clarissa anymore; this being Mrs. Richard Dalloway" (10). Clarissa feels a loss of self, a loss she tried to avoid by marrying Richard Dalloway instead of her young love, Peter Walsh. Clarissa felt she would have more independence with Richard; Peter wanted to consume her, possess her. When Peter interrupted the moment shared by the young Clarissa and Sally Seton, a moment after a blissful kiss, Clarissa saw the male interruption and later realized that if she and Peter were together, he would demand too much of her. Therefore, Clarissa turned to the man with whom she felt she would have more space, Richard. But Clarissa's fears could be coming true when she realizes that she is no longer just Clarissa, a singular identity, but rather is socially being fused into the identity of her husband, and she resents this. This resentment, not unlike the resentment so many women felt as they sacrificed their time, talents, and even blood during wartime, is a common characteristic in the women created by Woolf and Beauvoir, no matter what their class or station. From the upper middle class mother to the lower class maid, the women depicted by these writers were chafing at their societal roles, which they fulfilled with great skill, while secretly desiring more, and having no real plan as to how to achieve their ambitions.

\section{The Wife/Mother: The Family Woman}

Women's roles as wives and mothers were dictated and defined through biological determinism which concluded that women should be confined to certain arenas of life based upon biological and reproductive characteristics. According to Woolf's British and Beauvoir's French societies, there was no free will in deciding what role a 
woman should play in society, or rather, outside of society, within the confines of the private sphere. As discussed in the first chapter, the state viewed the job of the wife/mother as important in defining the strength of a nation in so far as she gives birth to the citizen/soldiers of the future. Therefore, a good woman/mother would give her state at least four children and raise them to become good citizens and servants of the nation. Woolf and Beauvoir utilize the wife/mother in their fictional works to describe women who live up to their social and political responsibility as each gives the reader an image of what a traditional family woman would look, act, and sound like. At times, however, these women secretly resent their positions as evidenced by the relationships between them and their husbands, as well as their offspring, especially their daughters.

Virginia Woolf creates many wives and mothers in her works, and none of her women embodies these roles more perfectly than Mrs. Ramsay in her novel To The Lighthouse. Mrs. Ramsay is the ultimate traditional wife and mother, the "Angel in the House" who is totally devoted to her family. She upholds the traditional values of women as she coddles the men in her life and rears her daughters to follow in her footsteps so they too can become wives and mothers. Mrs. Ramsay is critical of Lily Briscoe, who seems to be living a life outside of her biologically predetermined lot, and she gently "educates" Lily on this:

[Mrs. Ramsay] insist[s] that she must. . . they all must marry, since in the whole world whatever laurels might be tossed to her (but Mrs. Ramsay cared not a fig for her painting), or triumphs won by her (probably Mrs. Ramsay had had her share of those), and here she saddened, darkened and came back to her chair, there could be no disputing this: an unmarried woman (she lightly took [Lily's] hand for a moment) has missed the best of life. (49)

Mrs. Ramsay fears that Lily will waste her time trying to finish her painting and will not 
ever fulfill her true roles of wife and mother as she states that unmarried women never get to enjoy the best in life. This is a depiction of how women of Woolf's time unwittingly perpetuated the oppression of women. Woolf emphasizes this idea as Mrs. Ramsay haunts Lily's memory even in death: "Mrs. Ramsay has faded and gone, she thought. We can override her wishes, improve away her limited, old-fashioned ideas. She recedes further and further from us. Mockingly she seemed to see her there at the end of corridor of years saying, of all incongruous things, 'Marry, marry!"” (174). Mrs.

Ramsay's insistence upon marriage, and ultimately family is a sign of her willingness to conform, to fulfill the roles ascribed to her by her husband, and ultimately by society at large. She is content to serve as the mirror from which is reflected the image of her male family members and acquaintances twice their normal size as Woolf observes in $A$ Room of One's Own: "Women have served all these centuries as looking-glasses possessing the magic and delicious power of reflecting the figure of man at twice its natural size" (35). A dinner table incident between Mrs. Ramsay, her husband, and Augustus Carmichael portrays Mrs. Ramsay in her role of dutiful wife as she allows her husband to take precedence in their relationship when he becomes noticeably irritated: "He loathed people eating when he had finished. She saw anger fly like a pack of hounds into his eyes, his brow, and she knew that in a moment something violent would explode, and then -thank goodness! She saw him clutch himself and clap a break on the wheel, and the whole of his body seemed to emit sparks but not words" (TTL 95). Although Mrs. Ramsay says nothing, she too is irritated, not at Augustus, but at her husband; she continues to play the role of dutiful wife/mother, but we see that secretly, she questions her connubial docility: 
But why after all should poor Augustus not ask for another plate of soup?. . And why not? Mrs. Ramsay demanded. Surely they could let Augustus have his soup if he wanted it. He hated people wallowing in food, Mr. Ramsay frowned at her. . . . But he had controlled himself, Mr. Ramsay would have her observe. . . . Everybody could see, Mrs. Ramsay thought. (96)

The ambiguity of that last sentence is cleared up with the punctuation. The comma breaks up the notion that everyone could see what Mrs. Ramsay thought, but that would never have worked at that dinner table. Even though Mr. and Mrs. Ramsay knew what the other was thinking, and while the rest of the table could surely see Mr. Ramsay's irritation with Augustus and the soup, Mrs. Ramsay's thoughts are kept secret from the group, and her perpetuation of the status quo safely continues. No one could see that Mrs. Ramsay secretly criticized her husband

Mrs. Ramsay's thoughts are elsewhere disregarded by her husband as she tries to read a book to the amusement of her husband:

But she was becoming conscious of her husband looking at her. He was smiling at her, quizzically, as if he were ridiculing her gently for being asleep in broad daylight, but at the same time, he was thinking, Go on reading. You don't look sad now, he thought. And he wondered what she was reading, and exaggerated her ignorance, her simplicity, for he liked to think that she was not clever, not book-learned at all. He wondered if she understood what she was reading. Probably not, he thought. She was astonishingly beautiful. (121)

Mr. Ramsay must reduce his wife merely to a beautiful woman who does not understand her book. And he succeeds. Mrs. Ramsay puts her book down to devote her attention to her needy husband. However, what Mr. Ramsay desires is not necessarily his wife's attention, but rather he wishes for her to proclaim her love and devotion to him by saying that she loves him. Mrs. Ramsay will not. And she feels that this constitutes her triumph. He wants this, and she refuses it. However, in replacement of "I love you," Mrs. Ramsay 
concedes the point that it will in fact not be fine tomorrow, and that the trip to the lighthouse will have to be postponed: “'Yes, you were right. It's going to be wet tomorrow. You won't be able to go.' And she looked at him smiling. For she had triumphed again. She had not said it: yet he knew" (124). Again, the ambiguity of "yet he knew" deserves additional attention. What did he know? Did he know she loved him? Did he know it would not be fine? Did he know she had triumphed because he could not force her to say those words? But Mrs. Ramsay admits that she has trouble saying what she feels as if her thoughts, even emotions, are not allowed to be voiced, even when she is given permission: "It was only that she could never say what she felt"(123). Mr. Ramsay knows he has won on all counts.

As a mother, Mrs. Ramsay protects and coddles her young men, more so than she does her daughters, and she expects her daughters to do the same now and in the future when they marry and begin their own families. Paula Bennett in "The Mother's Part: Woolf and Morrison" discusses Mrs. Ramsay's preference for taking care of the men in her family and how this is a sign of Mrs. Ramsay's capitulation to the patriarchal authority that not only runs society, but her home as well. Bennett argues, "Although she presumably loves her four daughters as much as she loves her four sons, Mrs. Ramsay... treats her children in a painfully lopsided and stereotypical manner. . . Mrs. Ramsay's concern with protecting men is so great that she relentlessly subordinates herself to their needs, real or imagined" (127). Bennett analyses Mrs. Ramsay's thoughts as upholding the traditional role of the mother who tends to the needs of her young men and teaches her daughters to do the same, thus perpetuating the cycle of women subordinating their desires for those of the male family members: "Indeed, she had the whole of the other sex 
under her protection; for reasons she could not explain, for their chivalry and valour, for the fact that they negotiated treaties, ruled India, controlled finance" (TTL 6). Mrs. Ramsay admires men for their ability to handle public affairs, and in accordance with her private positions of mother and wife, tends to her male family members' private needs so that they may act efficiently in the world. Her husband is an example of the public sphere, and her sons are the future citizen/soldiers (literally as her son Andrew dies in the war: "[A shell exploded. Twenty or thirty young men were blown up in France, among them Andrew Ramsay, whose death, mercifully, was instantaneous]"), and she raises her daughters to give their lives to their families, (literally as Prue dies because she was a mother "[Prue Ramsay dies that summer in some illness connected with childbirth, which was indeed a tragedy, people said, everything, they said, had promised so well]") (132-3). The Ramsay children are raised by their mother in accordance with the desires of the state; they are citizens who give their lives to their country while trying to fulfill military and maternal duties.

Like Virginia Woolf, Simone de Beauvoir utilizes the image of the traditional mother to comment upon the position of women in society. She creates several mother/daughter relationships in her fiction to depict the mothers' desire to continue the cycle of male domination, but the daughters seem to rebel against the prescribed roles of their traditional mothers and societal mandates. Specifically, in The Woman Destroyed and When Things of the Spirit Come First, Beauvoir depicts the anxieties woman felt during her life in France and describes the changes taking place through the tensioned generation gap between mother and daughter. According to Yolanda A. Patterson in "Simone de Beauvoir and the Demystification of Motherhood," " the traditional family 
relationships touted as ideal by contemporary society could be devastating both for the mothers locked into their maternal molds and for the children, whose supervision often becomes their sole raison d'être"(87). Therefore, the cage in which the mothers of society find themselves locked are ironically the same cages in which they will lock their daughters, thus continuing the cycle of female oppression and confinement to the private sphere. Patterson also claims that because of her personal experience with her own mother, and through witnessing the anxiety-ridden relationship between her best friend Zaza Mabille (who died at 21 years of age) and her mother, Beauvoir was in fact:

hypersensitive to the detrimental influence of mothers who were overly manipulative, self-effacing, seductive or perfectionist with their children. These are the mothers who populate her fictional works and who constitute a chilling ensemble of personalities guaranteed to cause many a young woman to think before joining their ranks. (91)

Beauvoir's mother/daughter relationships are cautionary tales, warning women against falling prey to the cyclical nature of oppression. Her mothers and daughters are almost tortured in their strained relationships as described in a collection of short stories entitled When Things of the Spirit Comes First, written between the years 1935 and 1937. Anne Vignon and her mother Madame Vignon have a troubled relationship. Madame Vignon feels it her duty to raise her daughter in accordance with the beliefs of God and country, which counsel women to marry and bear children. Anne, however is an intelligent and energetic woman who has ambitions beyond sacrificing her life for her family. As Patterson explains, Madame Vignon feels it her "maternal duty to torment the intellectual and vivacious Anne with social obligations which would expose her to appropriate suitors" (91). Anne is caught between her loyalty to her overbearing and traditional mother and her desire to live a life defined on her own terms. In a conversation between 
Chantal, a friend, and Anne, the discussion focuses on God and his will in correlation with what a woman wants to do for herself:

"You have told me yourself that this total submission to the divine will is often only a cover for laziness and cowardice. Your resignation is in fact a definite choice: you choose peace. How do you know that God does not require of you the very thing that is the hardest, not renouncement but resistance, not refusing to live, but life itself?

"Don't torment me," said Anne in an agonized voice.... "I swore I should never, never hurt Mama and I have never stopped torturing her. When I gave way to her I felt contemptible: when I resisted I hated myself." (Beauvoir, When Things of the Spirit 140)

Anne can neither defy her mother nor resign herself to repeat her mother's life. This dilemma is important for Beauvoir, for she is asking her female audience to consider life options different from those of the traditional wife and mother. Why would a mother like Madame Vignon not want more for her daughter? Why would she desire to have her child live locked in a cage designed by a male-dominated society? Patterson explains that if Madame Vignon "can force her daughters to become devout middle-class wives and mothers like herself, her existence will somehow seem justified" (92). Wishing to continue the role of the traditional woman in French society and to uphold the "sacred" position of wife and mother, Madame Vignon figuratively fights her daughter to her death, as Beauvoir warns women of the dangers posed by the status quo. We are given details about Madame Vignon's relationship with her own mother, and what the reader sees is why Madame Vignon is the way she is. In her opening monologue, where she prays for her daughter's conformity, she confesses that she cannot talk to her daughter about men and claims: "I prefer not to ask the question directly: Mama never got anything out of me in that way when I was young." (Beauvoir, When Things of the Spirit 119). The strained communication between mother and daughter has not changed with 
the new generation. After Anne's untimely death, Chantal reflects on what they have all lost: "For her own part, she did not accept it; she wanted to remain faithful to the true Anne and she knew that death had come to her friend as an enemy. That was the cruelest part of it - that Anne should have been destroyed before she had fully existed. And nobody tried to save her now that she was on the far side of death" (Beauvoir, When Things of the Spirit 163-4). Anne was never able to fully realize her desires to escape from the traditional life of her mother.

In the collection The Woman Destroyed, and more specifically, in "Monologue," we are introduced to Murielle who is upset with how her life has turned out. A divorcee and now a wife to an estranged husband and a mother of two, she feels alone and abandoned, but ironically is herself a tyrannical mother, not unlike Madame Vignon, who drove her young daughter, Sylvie, to suicide at the age of seventeen. Invading Sylvie's privacy, reading her diary, interfering in her relationships, Murielle suffocated her daughter to a point that Sylvie saw death as her only escape. As Sylvie writes in her suicide note to her father, "Papa, please forgive me but I can't bear it anymore" (116). But Murielle is herself a product of an overbearing, hateful mother who paid loving attention to Murielle's brother rather than to Murielle. Patterson states, "Much of what is said throughout the monologue is an attempt by Murielle to prove that she was in no way responsible for Sylvie's death, which she considers an act of egregious ingratitude, aimed at primarily ruining her reputation as a conscientious and caring mother" (94). Murielle defends herself by claiming that the only reason she was hard on her daughter was because she did not wish for Sylvie to become a "whore like my mother" (97). Murielle's own relationship with her mother was troubled and her childhood unstable. 
Therefore, Murielle's own skills at motherhood were flawed because her only example of motherhood was flawed. She repeated the cycle. Sylvie felt that the only way out of that cycle was death.

Both Woolf and Beauvoir use the image of the traditional wife and mother to depict the traditional woman in their respective cultures, and ultimately these traditional figures are a source of social and cultural critique for these writers. They see the domineering wife/mother as a manipulator and as a perpetuator of female oppression. They control nothing else but how future generations are raised, and as they force the traditional agenda upon their offspring, they sometimes push to the death. Mrs. Ramsay's interest in the conventional roles of men and women are played out by Andrew and Prue Ramsay, but as they tried to live up to the expectations of their mother's traditional views, they die in the process. Andrew and Prue perish fulfilling the gender roles upheld by Mrs. Ramsay and conventional society. Lily survives in the absence of Mrs. Ramsay and is able to finish her painting, and she becomes representative of the new woman emerging into society and out of the clutches of prescribed female roles. Although her children (Lily included) loved Mrs. Ramsay, and although Mrs. Ramsay was not perpetuating traditional roles with malicious intent, she was nonetheless trying to teach these young people how to act properly in traditional society.

The deaths of Beauvoir's Anne and Sylvie were the result of these two daughters' attempts at escaping the tyrannical clutches of their own mothers who wished to lock their daughters into the societal cages they themselves had to inhabit throughout their lives. These examples are Woolf and Beauvoir's comment on how social conformity can prove to be a death sentence for the new woman, how early $20^{\text {th }}$ century society was not 
conducive to the emergence of the new woman, and how the current situation and the current definitions in the world do not allow for this new woman to define herself. These traditional women and their families offer cautionary tales of what can happen if the definition of a woman remains that of the traditional woman rather than redefining this new entity emerging in society.

\section{The Keeper of the House: Cleaning All The Private Parts}

Along with being a wife and a mother, the traditional woman had to keep house either through her own labor or through the instruction of servants, depending upon her task and social class. Both Woolf and Beauvoir take up the image of the cleaning woman in their works, for housework was deemed woman's work. However, many of the house cleaning images produced in the works of Woolf and Beauvoir are not free from anxieties, for these "cleaners" shake up the dust of the past and bring to light the imperfections of the present, both in the private sphere as well as the public. In two of Woolf's most famous novels, fictional characters Clarissa Dalloway in Mrs. Dalloway and Mrs. McNab in To The Lighthouse, in their own ways, tend to the daily tasks of domesticity. Simone de Beauvoir also deals with the idea of the domestic worker, but in a very different way, as she describes the relentless nature of housework in "The Married Woman" chapter of The Second Sex. While Woolf and Beauvoir are writing in different times and different cultures, their similarities are striking, for they were both affected by war and the destruction of the war machine driven by the dominating patriarchy. Looking at the images of a woman in her stereotyped role of tending to the home adds yet another layer to the image of the traditional woman during the first half of the $20^{\text {th }}$ century. 
In the absence of Mrs. Ramsay, Mrs. McNab in Woolf's To the Lighthouse must be the domestic authority. After the many deaths in the Ramsay family, including the death of Mrs. Ramsay, Mrs. McNab reflects on what has occurred in that family and in that house, both once so full of life and now falling apart. Mrs. McNab, along with Mrs. Bast, goes to the Ramsay house, which has been run down with years of neglect. As the housekeeper, it is her responsibility to put in order that which has become chaotic after the death of the lady of house, Mrs. Ramsay. Mrs. McNab thinks to herself:

She sighed; there was too much work for one woman. She wagged her head this side and that. This had been the nursery. Why, it was all damp in here; the plaster was falling. Whatever did they want to hang a beast's skull there? It had gone mouldy too. And rats in all the attics. The rain came in. But they never sent; never came. Some of the locks had gone, so the doors banged. She did not like to be up here at dusk alone neither. It was too much for one woman, too much, too much. She creaked, she moaned. She banged the door. She turned the key in the lock, and left the house alone, shut up, locked. (TTL 137)

So connected to domestic work, Mrs. McNab seems to become as broken down as the house as she creaks like the house creaks, moans as the house moans. She banged like the doors without locks, and she was alone at dusk as the house has been alone during the dusk of this family's life. Mrs. Bast too "creaked. They were old; they were stiff; their legs ached. They came with their brooms and pails at last; they got to work" (TTL 139). With the loss of the lady of the house, the home has fallen into disrepair, and Mrs. $\mathrm{McNab}$ is overwhelmed by this, claiming that it is too much, not just for one person, but for one woman, for it is the woman's responsibility to tend to the home and its ambiance. Because Mrs. Ramsay abandoned the house in her death, the house was thus abandoned completely, for there was no one woman any longer to see to its upkeep: "The house was left; the house was deserted. It was left like a shell on a sandhill to fill with dry salt grains now that life had left it" (137). It was now Mrs. McNab's responsibility to bring the 
house back to life as the Ramsay family wants to return after having been absent for so long. She must dust the furniture, scrub the baths, and tend to the laundry; the family (or at least one of the young women in the family) hopes to see the home as it had always been:

All of a sudden, would Mrs. McNab see that the house was ready, one of the young ladies wrote: would she get this done; would she get that done; all in a hurry. They might be coming for the summer; had left everything to the last; expected to find things as they had left them. Slowly and painfully, with broom and pail, mopping, scouring, Mrs. McNab, Mrs. Bast, stayed the corruption and the rot.... (139)

The responsibility was hers, and expectations were high. It falls to the woman to see to it that the house is a home with all the comforts that the family is accustomed to having. However, no matter what Mrs. McNab does to the house, the family would find differences, for too much time had passed, and too many things had changed. As Mrs. Bast thinks:

They'd find it changed. She leant out of the window .... The might well ask what had been done to it? Seeing how old Kennedy was supposed to have charge of it, and then his leg got so bad after he fell from the cart; and perhaps then no one for a year, or the better part of one; and then David Macdonald, and seeds might be sent, but who should say if they were ever planted? They'd find it changed. (TTL 140-1)

Upon the family's return, both Mrs. McNab and Mrs. Bast believe they will be disappointed at what time has done to the house. Mrs. Bast details the men who were supposed to take care of the home, but they failed to do so, and it was now up to these women to return the house to its former appearance, but that was going to prove difficult for these two housekeepers.

The impact of Mrs. Ramsay's absence and the power Mrs. McNab has over "fixing" the house for the family's return is important in regard to what was expected of 
the woman in the home. Victoria Rosner in Modernism and the Architecture of Private Life discusses the image of the wife/mother/homemaker in Victorian homes and connects this image to Woolf's own childhood home as the family sought to renovate the 22 Hyde Park Gate residence that was quickly becoming too small for the family. Rosner reflects on the addition of two stories to the top of the Woolf house and on Virginia's thoughts about that home: "The father may be the house's brain, but the mother is its body" (71). What Rosner is referring to here is a passage from Woolf's Sketch of the Past where she discusses the presence of her own mother in the home: "The tea table, the very hearth and center of family life, the tea table round which sat innumerable parties; on which when Sunday came—-the tea table's festival day—pink shell plates were placed, full of very thin slices of white and brown bread and butter. The tea table rather than the dinner table was the center of Victorian family life...." (118). Rosner contends that the tea table represents Julia Stephen as she embodies the heart of the home, the center of the family body, and while the father may be the brains of the family, as Leslie holds office atop the new addition of the Hyde Park Gate home, it is Julia's heartbeat (and tea table) that keeps the home alive. Woolf continues in $A$ Sketch of the Past, describing her mother's place at the tea table: "It was the center, the heart of the family. It was the center to which the sons returned from their work in the evening; the hearth whose fire was tended by the mother, pouring out tea" (118). Julia Stephen, like Mrs. Ramsay, was the domestic center around which all revolved. As Rosner claims, "Julia Stephen is the central figure at 22 Hyde Park Gate in her daughter's eyes not because she has supreme authority in the house but because she embodies it, and family life, in the tradition of the Victorian domestic angel"(71). Like Julia Stephen, Mrs. Ramsay is the domestic angel, and in her 
absence, the house falls apart only to be revitalized by another woman, a housekeeper, Mrs. McNab, who toils to return the home to its pre-war, pre-death state. The necessity of Mrs. Ramsay's and then Mrs. McNab's presence had in keeping the house running is the ultimate role of the traditional woman, tending to the private needs of the family.

It is quite a leap to compare Woolf's Clarissa Dalloway to Mrs. McNab because Clarissa is not a domestic worker by trade but is rather a housewife who is in fine financial and social standing through her political husband's position in society. However, one must not ignore the fact that in the opening line of the novel, Clarissa Dalloway takes on a chore fit for a servant: "Mrs. Dalloway said she would buy the flowers herself'(MD 3). But why would an upper class woman take on the duty of one of her servants? Woolf answers this question in line two of the text: "For Lucy had her work cut out for her" (3). Clarissa is helping the domestic worker, Lucy, prepare for the party that evening by taking one of the mundane responsibilities upon herself. Victoria Rosner comments upon Clarissa's decision:

Woolf's Clarissa Dalloway provides an example of how women used the stimulation of the city to counter the deadening stasis of the home. ... Clarissa is drawn to forward motion above all else. . but is she herself actually making headway? Like all other female characters in the novel, Clarissa goes out into the city only to shop; having accomplished her errand she returns home immediately, and by the same route as before. (148-9)

After she returns home from her chore, Clarissa takes herself upstairs to her bedroom where she has slept alone since falling ill, and she continues to prepare for her party by tending to her wardrobe for the evening. She realizes that the green gown she wishes to wear that night has a tear and she decides to fix it herself: "She would mend it. Her maids had too much to do. She would wear it to-night. She would take her silks, her scissors, her - what was it? -her thimble, of course, down into the drawing-room, for she must 
write, and see that things generally were more or less in order" ( $M D$ 37).Clarissa continues to "plunge" herself into domestic work regardless of her class and station. While there remains a clear demarcation between herself and her hired servants, she is still an equal with these domestic workers as she engages in their activities. As she mends her dress she is at once a seamstress and an authority figure, overseeing the goings-on in preparation for her party. Clarissa is the traditional woman not only in her roles of lady of the house, wife, mother, and hostess, but as a domestic worker as well.

Clarissa's sympathy towards her house workers and her desire to take some of the burden off their shoulders as they prepare for her party is reminiscent of Woolf's own struggles with her domestic workers and her opinions of the working class altogether. In her diaries, Woolf details her experiences with her servant Nelly Boxall whom she appreciates for her willingness to tend to her work, but for whom she secretly holds a very low opinion. In two particular diary entries, Woolf admits her almost elitist opinion of Nelly:

Of course, one is right about Nelly — right that she is, in bad moods almost insufferably mean, selfish, \& spiteful; but--\& this is an interesting psychological remark, she is in a state of nature; untrained; uneducated, to me almost incredibly without the power of analysis or logic; so that one sees a human mind wriggling undressed - which is interesting; \& then, in the midst of one's own horror at the loathsome spectacle, one is surprised by the goodness of human nature undressed. For example, she had thought I had given her notice permanently; but instead of giving way-\& yet she had nowhere to go-to rage or spite, she bicycled into Lewes to get us cream for dinner: the motive being genuine I think; we must not suffer; \& how could she leave us without a cook? It is this mixture that one can't understand; \& that makes one always plunge so heavily in dealing with her. $(3: 241)$

Woolf's private thoughts about Nelly are class driven as she comments on Nelly's lack of education, logic, or reasoning. Woolf almost seems to be reducing Nelly to a primitive level as she refers to Nelly as "human nature undressed" as if she were wild and free 
from the constraints of civilized society. In another diary entry Woolf continues her complicated opinion of Nelly and writes: "How unwilling I am to have her back. Partly the silence is so grateful; \& partly the absence of lower classes. I think with real shrinking of having her in control again. Yet she is obliging friendly affectionate; \& I cannot bring myself to talk to her as I should. I am always seeing myself told to "leave my room" (3:305). Woolf's negative and uneasy feelings towards the lower, working classes extended to society as a whole. Almost as if she felt some guilt for being part of the privileged set, Woolf had a difficult time relating to the lower-class women for whom she worked to make life better. Bernice A. Carroll discusses Woolf's class issues in her article "“To Crush Him in Our own Country": The Political Thought of Virginia Woolf." Carroll argues that Woolf's opinion of the lower class was complicated and riddled with a bit of guilt:

[Woolf's] attitude was far from hating, despising, or ignoring working women. She worked actively with the Women's Cooperative Guild, hosted their meetings at her home.... But she felt a sense of isolation, perhaps even imprisonment, in the class of "educated men's daughters," and a reticence based on recognition of the dangers of what today is called "defining other people's oppression" for them. Her own class, the daughters of educated men, she felt to be "weaker than the women of the working class." ... While she believed that her class should use whatever resources and freedoms it had to begin to build a new society, and above all to speak the truth, she was doubtful of its power to effect major social change, and even more doubtful of its right to carry any message or instruction to the class of working women. (123)

As Carroll points out, Woolf's fear and awareness of not being able to relate to working class women (and perhaps not wanting to relate to working class women such as Nelly Boxall) created a gap in what she felt about women in society and what she wanted for women in society. Clarissa Dalloway employs servants in her household but then takes on some of their responsibilities, almost as a show of guilt for their service to something 
they will not be allowed to enjoy, depicting the same ambivalent feelings Woolf herself had towards the domestic roles of women in society at that time.

While Virginia Woolf depicts the traditional woman as housekeeper in To The Lighthouse and Mrs. Dalloway, Simone de Beauvoir takes a different approach on the same topic. In The Second Sex, Beauvoir details the Sisyphian nature of housework that is forced upon women of all social classes, like Woolf's Mrs. McNab and Clarissa Dalloway. The unending torment of housework, i.e. scrubbing an object that will later become dirty again, has always been justified under the patriarchal definition as a woman's responsibility that falls within the private sphere. Her role is to tend to the husband, children, and home, and daily housework is a large part of that role.

The problem for Simone de Beauvoir where housework is concerned is that it is a never-ending project: "Few tasks are more like the torture of Sisyphus than housework, with its endless repetition: the clean becomes soiled, the soiled is made clean, over and over, day after day" (SS 451). In the section entitled "Married Woman" in The Second Sex, Beauvoir details this problem for women of all classes claiming that while the housework assigned to women is fraught with bitterness, anxieties, and ambiguities, it nonetheless remains a primary responsibility of the traditional woman in French culture.

Simone de Beauvoir's description of the housewife and her work is not flattering. On the contrary, because of the housewife's condition, one of repetition and thanklessness, she becomes, in Beauvoir's opinion, an anal and bitter being who always seems to lose her battle against dirt:

But it is a sad fate to be required without respite to repel an enemy instead of working toward positive ends, and very often the housekeeper submits to it in a kind of madness. ... When any living being enters her house, her eye gleams with wicked light: "Wipe your feet, don't tear that place apart, leave that alone!. . . She 
wishes those of her household would hardly breathe; everything means more thankless work for her. (SS 452)

Beauvoir goes on to describe this woman as "Severe, preoccupied," "overprudent and avaricious," "bitter and disagreeable and hostile to all that lives" (SS 452).

The traditional woman is confined to her home, the only place she can exert any sort of control. But that control is itself an illusion, for while she is lady of the house, or mère au foyer, that control, and thus her happiness, is subject to change at the whim of her husband and/or her children. Whether their intent be malicious or not, they can very quickly and easily destroy an entire day's worth of her work.

She also seeks the approval of her husband and children, so much so, that this is seen as a form of payment. If that approval is not given, she feels like a failure:

The validity of the cook's work is to be found only in the mouths of those around her table; she needs their approbation, demands that they appreciate her dishes and call for second helpings; she is upset if they are not hungry, to the point that one wonders whether the fried potatoes are for her husband or her husband for the fried potatoes. (SS 455)

Outside of the family, the housewife/cook possesses no means to validate her efforts, for if praise does not come from external sources, she has no substance, education, or experiences to create validation internally. She has no economic or professional independence through which she can develop her own confidence and worth. Instead, her value and definition are assigned to her by husband and children. As Beauvoir explains, "The worst of it all is that this labor does not even tend toward the creation of anything durable.... It is really too bad to have husband and children tramping with their muddy feet all over her waxed hardwood floors!" (SS 454). The housewife spends her time trying to preserve the things in the home, but as the family lives in the home each day, they destroy her work. This preservation/destruction cycle mimics the social cycle that 
the traditional woman finds herself in as the patriarchy continues to wage war across Europe, destroying not only the literal landscape, but the human landscape as well, reshaping the world, and thus creating a need to reshape roles in society, including those assigned to the traditional woman. Toril Moi in "'Independent Women' and 'Narratives of Liberation"” discusses the predicament in which Simone de Beauvoir finds women:

For Simone de Beauvoir, economic independence is the sine qua non of women's liberation. As long as women are prevented from earning their own living, they will always be dependent on others. Women actually seeking paid work, however, are confronted with class exploitation and sexist oppression at every turn. Oppressed at home, they find themselves exploited, underpaid and alienated at work. ... Under such conditions, women are caught in an internal double bind. ... (74)

Many women worked full time within the home, but had nothing to show for their efforts. Without any kind of compensation for their work, women had to rely on both financial and emotional support from the family; if that support was not given, women were destitute.

Beauvoir describes not only the life of a woman who is strictly a housewife, but also details the plight of the working woman. Women who did have positions outside of the home were not alleviated of their household duties. On the contrary, the public woman had to return to her fulltime traditional role each day in the private sphere: "Recent studies show that for married women housework averages about thirty hours per week, or three fourths of a working week in employment. This is enormous if done in addition to a paid occupation. ..." (SS 454). Beauvoir admits that while some young couples newly married may have ideals about equality and actually believe that they are basing their marriage on such ideals, this is a fallacy: "Many young households give the impression of being on a basis of perfect equality. As long as the man retains economic 
responsibility for the couple, this is only an illusion. It is he who decides where they will live, according to the demands of his work. .. their standard of living is set according to his income...."(SS 480). Since the husband is the primary (or solitary financial) provider, the traditional housewife must tend to her home wherever he deems that home to be. Practically speaking, his role is very important, for without his financial support, there would be no home. However, the housewife can do nothing to alleviate this pressure placed up on the traditional man because she has very little means to provide a living for her family herself. She is stuck in her role, remaining dependent upon the dominating male in her family.

The dramatic changes taking place in Great Britain during Virginia Woolf's lifetime as a result of the First World War had an impact on women's lives. As discussed in the first chapter, women were moving from the private sphere and into the world to gain an education and earn a living. However, the bifurcated nature of gender roles in society was not so quick to change, and women were caught in the crossfire of a war that was being waged on the battlefield as well as on the social battlefront. As women emerged from the home, they developed a taste for economic freedom, but society at large was not going to change that easily. Woolf depicts the image of the traditional wife, mother, and housekeeper, a woman who no longer fits in with the changing world. As the politics of identity shifted, there became a new categorization for women. Amongst women, the norm/other relationship was being created where the traditional woman no longer fit in the shifting culture and was therefore becoming "other-ed" against the New Woman who was making herself known in the world as she slowly, and under difficult circumstances, was achieving precedence. The matriarchal "Angel in the House", like 
Woolf's Mrs. Ramsay, was becoming obsolete, a dying breed that was no longer relevant in a changing world, for the First World War killed this image as it had killed so many things. Society longed for days long gone, the "good ol' days" of prewar Britain, and this was the cause of the traditional backlash, pressuring women back into the private sphere. The "damage," however, had already been done, and society, against all its efforts, was changing.

Simone de Beauvoir, writing later than Woolf, comments upon the same predicament in France that Woolf saw in Great Britain. She warned women against falling prey to traditional sex roles, in both her fictional works as well as in The Second Sex. Her fictional mother/daughter relationships depicted traditional mothers as well as young daughters who fought against that tradition. Beauvoir cleverly depicted "tradition" (mothers) as killing the future (daughters) just as the war, waged by traditional society, was destroying the world. The quest for female achievement and independence was not without its obstacles, but for Beauvoir, it was a necessary quest.

Beauvoir saw the traditional lot of women as torturous. As she discusses in The Second Sex, the role of the wife as housekeeper is a punishment, a doomed position that has no agreeable end. It is a never-ending cycle of working to please others and only through their praise can the housekeeper find satisfaction. Beauvoir's argument is based on it the idea that none of the roles assigned to women have anything to do with their inherent nature; all roles and characteristics are social constructions. If women are interested in changing their roles, they must refute the definition prescribed for them by the social structure. It is important to remember that when Beauvoir was writing about the traditional role of women, the state was vehemently promoting the role of 
motherhood in society, as many European nations were, when faced with a population crisis. To refute the roles of wife, mother, and housekeeper, to refute the traditional roles set up by society would be to reject a maternal mandate that was being espoused in society, but it would also be accepting something new, something other than the "other". Women needed redefining in the changing world.

World War II also did a great deal to shatter the traditional roles of men and women in society. Once again the nations called upon women to fulfill their patriotic duties, but rather than being mothers of future soldiers, as was their patriotic duty before, the state asked them to work both in the military and as civilians to aid the war effort. Ann Allen argues in Women in Twentieth-Century Europe that "The Second World War broke down the distinction between the home and the battlefield. More civilians than soldiers died, and both men and women were involved as combatants, as workers, and as the perpetrators and victims of violence, atrocity, and genocide" (60). While different European countries were uncomfortable with women taking a more visible and active role in the war effort both on the battle front and the home front, women none-the-less were needed and even drafted into the war effort by different governments.

In Great Britain, the participation of all able-bodied people in the war effort was important. Again, as women were drafted and volunteering to help, the public worried that sexual immorality was to follow. As Allen claims:

The situation in Britain, the under constant attack by German bombers, was far more vulnerable. Desperate for manpower, Prime Minister Winston Churchill responded enthusiastically to the suggestion that women might help to defend the homeland in order to free up men for overseas combat. Over the course of the war, 125,000 British women were drafted into military service by the National Service Act, and 430,000 more volunteered. ... Churchill wrote to the secretary of State for War that the "complex against women being involved in any kind of lethal work" must be overcome. (61) 
Allen goes on to explain that only a limited number of women were actually in combat situations, and most women served in non-combatant positions such as nursing and secretarial work. Eventually, as the need for workers grew, so did the opportunities for women to fill trade positions in electrical and carpentry work. The number of women in war related work positions increased dramatically. As Allen explains:

The number of women engineers rose from 97,000 in 1939 to 602,000 in 1943, and the percentage of women in such formally all-male branches as the electrical and chemical industries, transport, electrical work, and shipbuilding climbed from 14 percent in 1939 to 34 percent in 1943. The percentage of all females 1459 in the workforce, which in 1934 had stood at 34.3, had reached 44.5 percent by 1943. Educated women were directed into white-collar jobs, a category that also grew considerable. (65)

However, the female workforce in France during World War II differed from that of Great Britain, for France surrendered to German forces early in the war and was then governed by the Vichy regime, a governing body that worked in collaboration with the German government. As Allen states, the Vichey government reversed many policies related to working married women, limiting their access to jobs, and only in 1944 when the war was almost over did the government mobilize "all women aged 18 to $45 . \ldots$ Some young, unmarried women French women volunteered or were forced to do warrelated work in Germany" (67). According to Allen, the Vichey government enforced a strict moral code upon French women promoting "a domestic and conservative ideal of femininity and cracked down on sexual immorality. In France and Germany, abortion became a crime against 'state security' that was punishable by death" (69). Once again the state worked to control the bodies and behavior of women in society and cut down on the amount of women participating in the war efforts through military and civilian work. 
After the conclusion of World War II, there was once again a traditional backlash against women, forcing them from the public sphere back to their domestic roles, but changes had already taken place, and there was no turning back. Regardless of the state's or society's attempts to hold women to their traditional roles in the name of tradition, and in the interests of the strength and power of the state, both the First World War and World War II had damaged the previous culture too much and left in its wake a new woman who was yet to be defined. 


\section{CHAPTER THREE: VIEWING WOOLF AND BEAUVOIR THROUGH A PHILOSOPHICAL LENS}

Looking at the cultural framework in which Woolf and Beauvoir were writing is necessary in order to argue that they were trying to inagurate a new way to discuss women in a changing society. The history of the women's movement and the traditional image of women in French and British cultures as depicted by Woolf and Beauvoir is the first step in arguing that a new woman was emerging in society. However, before we can examine who that new woman was, it is important to recognize the theoretical and philosophical groundwork for the argument of (An)Other gender, a human being outside of the confines of societal definition. Existentialism and phenomenology allow for a philosophical validation of this idea. The existential argument for (An)Other gender comes from the understanding that human beings cannot be understood or categorized solely by biological science, but rather individual choice and experience are inherent in defining the self, and therefore there must be (an)other sphere where an individual may examine an experience outside of societal gender attributions. As Sartre claims in "Existentialism is a Humanism", "existence comes before essence" : "We mean that man first of all exists, encounters himself, surges up in the world -- and defines himself afterward. . . He will not be anything until later, and then he will be what he makes of himself" (289-90). One cannot define the essence of another human being because the self is determined by the individual through the choice of an experience. Woolf and Beauvoir explore identity in their works, especially their autobiographical pieces, 
describing individual experiences as central to their own identities and development as a "self." Utilizing an existential framework, arguing against the predetermination of gender roles, one moves to an ontological dilemma: what is gender and what are its characteristics? This question is not about biological sex. Obviously, there are biological differences between a human male and a human female. Aside from biological sex, what are the definable components of a gendered man and a gendered woman? Can we determine that men and women possess inherent characteristics that make valid a social separation of roles, rights, and opportunities? Both Virginia Woolf and Simone de Beauvoir would argue that no such separation is valid. Gender characteristics are socially dictated and have no truth outside of societal constructions. Looking at the phenomenological issue, the meaningful experience of the self is important, and gender has no place in validating or negating that experience. Consciousness is not gendered. Gender is merely a social category that one might utilize in order to think about a meaningful experience, but this category is not essential.

However, since gender is so prominent in society, especially in the traditional worlds of Woolf and Beauvoir, we see anxieties felt by these two authors as they try to come to terms with their own experiences being filtered through a gendered society. Woolf and Beauvoir focus more on personal experiences because they believe that not only is a single personal experience meaningful, but also how the self interprets that experience is meaningful. As Woolf stated in "Modern Fiction," "Look within and life, it seems is very far from being 'like this.'. . The mind receives a myriad impressionstrivial, fantastic, evanescent, or engraved with the sharpness of steel. ... The moment of importance came not here but there. ..." (CR 149-50). A binary gender system is 
inadequate in exploring the experience of the self or being-in-the-world as it determines which moment is important. However, the goal of this argument is not to deny that women and men exist, but rather to argue that human biology is not necessarily a significant factor in formulating an experience of the self. While the patriarchal definition and social separation of gender roles cause problems of equality, we do not necessarily need to eradicate those roles, but rather must argue that those roles are only valid if a particular individual deems them valuable for the self. The problem occurs when an outside Other places restrictions upon a self under the guise of finite gender roles. Therefore, the patriarchal rule of society stems from the belief that those gender roles represent an essential reality, and social constructions are based upon that "reality." This argument is taken up in much feminist criticism, especially that concerned with the writing and discussion of the female body in patriarchal language, and allows for a theoretical framework in which to work with the polemical and autobiographical writings of Woolf and Beauvoir who argue against the validity of the binary gender system that culturally constructs women's subject position. ${ }^{1}$

\section{Woolf and Beauvoir's Existential and Phenomenological Roots}

Both Virginia Woolf and Simone de Beauvoir placed great emphasis upon their own personal experiences as women during the tumultuous years of the First World War and then World War II, and these experiences are reflected in autobiographical writings such as Woolf's Moments of Being and Beauvoir's Memoirs of a Dutiful Daughter. Both works offer a phenomenological study of the definition of the self and of female experience. What did it mean to be a woman at that moment? The phenomenological 
quest arose as the balance of power shifted, wrought by war, industry, and women taking on new roles in society and leadership in shaping that society into a viable place for women. With this upheaval, new awareness of being a self in the world opened up theoretically and realistically. Thus perceived ideas about the interconnectedness between gender and society became questionable. But if those truths were proven false, what next? How does one define the self without gender classifications and societal constructions? Woolf and Beauvoir both experienced female identity dilemmas, for there was no way to express what the self was without interpreting male categories as "norm," and female as "other." As Beauvoir claims in The Second Sex, "[Woman] is determined and differentiated with reference to man and not he with reference to her; she is the inessential as opposed to the essential. He is the Subject, he is the Absolute: she is the Other" (xxii). Beauvoir and Woolf testify to an awareness of this otherness in their autobiographical works and describe the anxieties they felt as they tried to define their experiences not just as women, but as unique selves in a world defined by shifting roles and definitions.

In "A Sketch of the Past" Woolf describes a series of childhood moments during which she searched for meaning but lacked a suitable way to describe what she was feeling or experiencing. Woolf writes:

Again those moments of being. There was the moment of the puddle in the path;. . . everything suddenly became unreal; I was suspended; I could not step across the puddle; I tried to touch something. . . the whole world became unreal. Next, the other moment when the idiot boy sprang up with his hand outstretched ... and without saying a word, with a sense of horror in me, I poured into his hand a bag of Russian toffee. But it was not over, for that night in the bath the dumb horror came over me. Again I had that hopeless sadness; that collapse I have described before; as if I were passive under some sledge-hammer blow; exposed to a whole avalanche of meaning that had heaped itself up and discharged itself upon me, unprotected, with nothing to ward it off, so that I huddled up at my end of the 
bath, motionless. I could not explain it; I said nothing. . . (MB 78)

Woolf's phenomenological account of her experiences allows the reader a glimpse into the despair she feels at her inability to express her emotional reactions at those moments and the desire she has to find a suitable mode of expression. As the young Woolf searched for an understanding of her world and her experiences, she was met with horror at her inadequacies or her perceived inability to act out, to jump across that puddle, to refuse the boy candy, or to block the blows from the sledgehammer. She seemed helpless in the world as it surrounded her and seemingly attempted to consume her. Woolf's struggle to articulate what she was feeling on that day, her inability to put her various experiences together to make sense out of what was happening at each moment was a source of existential anxiety for her. In The Unknown Virginia Woolf, Roger Poole connects Woolf's puddle experience to the fictional character Rhoda in The Waves as she suffers similar anxieties:

Also, in the middle, cadaverous, awful, lay the grey puddle in the courtyard, when, holding an envelope in my hand, I carried a message. I came to the puddle. I could not cross it. Identity failed me. We are nothing, I said, and fell. I was blown like a feather. I was wafted down tunnels. Then, very gingerly, I pushed my foot across. I laid my hand against a brick wall. I returned very painfully, drawing myself back into my body over the grey, cadaverous space of the puddle. This is life then to which I am committed. (Waves 64)

Poole argues that Rhoda's identity crisis stems from Woolf's own experience stating that "Virginia retained [this memory] as a painful initiatory moment of existential insecurity all her life" (202). Both Virginia and Rhoda try to reach for something stable to help them across their identity gap as they search for meaning.

In an earlier passage of "A Sketch of the Past," Woolf details what she calls a possible philosophy, an attempt to control details and define a being. She writes: 
I hazard the explanation that a shock is at once in my case followed by the desire to explain it. I feel that I have had a blow; but it is not, as I thought as a child, simply a blow from an enemy hidden behind the cotton wool of daily life; it is or will become a revelation of some order; it is a token of some real thing behind appearances; and I make it real by putting it into words. It is only but putting it into words that I make it whole; This wholeness means that it has lost its power to hurt me; it gives me, perhaps because by doing so I take away the pain, a great delight to put the severed parts together. $(M B 72)$

Woolf calls this idea of creating order out of chaos through writing a kind of personal philosophy: "We are the words; we are the music, we are the thing itself" $(M B 72)$. Using an existential lens, Woolf seems to believe that through the creation of a personal art, an existential subject can define itself, and ideally, gender would have very little to do with that definition.

Woolf used the written word to create order out of her experiences. However, throughout her career, Woolf saw the written word as problematic, for despite her freedom to wield her own pen, she felt the constraints of the male dominated literary tradition and struggled to write from a perspective and a voice uniquely her own, a voice that was not filtered through the patriarchal language structure. Woolf viewed this language as dangerous and violent as she was thrust into the middle of the First World War.

The profound effect of the First World War on Woolf's modernist aesthetic is undeniable. Not only did the war and the British Liberal political schism influence the culture as Modernist writers knew and understood it, but it also affected the way those wishing to express their thoughts about the war crisis actually did so. The war influenced the way men and women perceived roles in the world, both publicly and privately, and due to the shifting society, writers looked to express change in a way that would capture the nuances of the human condition at that time. Virginia Woolf recognized this moment 
in history, understanding that the world would be forever changed and that a new social, cultural, and political landscape would prevail. How to understand and best express that reality was the Modernist challenge.

This challenge was not without its obstacles. The political instability of public life began to reflect for the modernists the chaos they viewed within private life. For the writer, language was the only available tool to express these different types of chaos, but the use of language the modernists had always known was now inadequate to express what they were experiencing. Politicians and journalists abused public language, using it to manipulate the public into a war that the government, according to its own party dogma, should have opposed. Acknowledging the inferiority of the traditional tools of expression, the modernists utilized their creative talents to revamp language in such a way that they would be better able to capture the self during the crisis of the war. In The Cambridge Companion to the Modern Novel, Morag Shiach argues that modernism "is characterized both by a recognition of fragmentation and by a desire to resolve or overcome this through the integrity of aesthetic form. The urgency of achieving such integrity was apparently intensified by the traumas of the First World War"(10).

The modern aesthetic form manifests itself in different experimental methods of writing and language manipulation. Woolf's utilization of the stream of consciousness method was a valuable tool for her because she was interested in taking the focus off of public life and turning the gaze inward toward phenomenological representation of the experiential conditions of being in the world. Even the idea of time, something seen as fixed and marked by public clocks, is challenged by Woolf when she seeks to manipulate time within her works, showing the inadequacy of merely keeping time and moving her 
characters and readers from the present to the past and back again, all within a few pages, a few sentences, or even a few words.

As war ravaged the European landscape, the binary gender system so prominent in "civilized" society seemed useless in attaining a clear understanding of the self outside of gender. How were women to define "subject positions" without using current masculine criteria? Major events such as the world wars and suffrage created a space in which new questions could be raised about how to negotiate a world of such change and devastation. Out of that devastation, could society construct a new definition of gender that no longer depended upon the binary gender system? Could human beings be defined, or rather "un-defined," through the denial of biological considerations?

Both Woolf and Beauvoir asserted the characteristics of an existential project in their writing as each denied the idea that truths about being can be discerned from considering gender. In both writers' opinions, gender was a tool, a fallacy used by patriarchy to force certain facts upon the female sex concerning their abilities to work, learn, and live in society.

Throughout her autobiography, Memoirs of a Dutiful Daughter, Simone de Beauvoir reflected upon instances in which she became aware of herself, and this awareness seemed to come with an element of surprise as she tried to form or define her own identity. She writes:

In the family photographs taken. . . can be seen ladies. . . and gentleman. . . all smiling at a baby; there are my parents, my grandfather, uncles, aunts; and the baby is me. My father was thirty, my mother twenty-one, and I was their first child. I turn the page: here is a photograph of Mama holding in her arms a baby who isn't me;. . . I am two and a half, and my sister has just been born. . . . I had a little sister: that doll-like creature didn't have me. (5)

Beauvoir discovers herself in those family photographs, and she takes ownership of her 
identity and decides that her sister belongs to her rather than the other way around. Another example of Beauvoir's identity awareness occurs when she comes to the realization that she will grow older, and this caused some anxiety for the young girl:

I would look at Mama's armchair and think: 'I won't be able to sit on her knee anymore if I keep growing up.' Suddenly the future existed; it would turn me into another being, someone who would be still, and yet no longer seem, myself. I had forebodings of all the separations, the refusals, the desertions to come, and the long succession of my various deaths. ... I kept on growing and I realized that my fate was sealed: I was condemned to be an outcast from childhood. (7-8)

Beauvoir gives a phenomenological account of coming to terms with aging and entering a different realm of the social world. She goes on to explain that as she grew older, she became interested in her appearance and took pleasure in looking at herself in the mirror. She also confesses that she became increasingly interested in attracting the attention of men, "seizing any look or word that would snatch me out of my childhood limbo and give me some permanent status in their grown-up world" (8). Beauvoir's childish attempts to move from childhood to adulthood give voice to an early identity crisis where at one moment she is clinging to her youth and in the next, she is flirting with adult men. Her need to define her place in a changing world as she experiences her changing body was great as the young Beauvoir sought her place and role in society.

Seeking authentic methods to define identity and existence, especially for those who were forced into definition by an oppressor and had little freedom in creating themselves as authentic selves, was an important project for Simone de Beauvoir. According to Sonia Kruks in "Simone de Beauvoir and the Limits to Freedom," Beauvoir and Jean-Paul Sartre agreed that human beings are defined as projects with agency: "For Beauvoir agrees with Sartre that only things are subject to causality. Humans on the contrary, make themselves as free projects" (113). They are able to do this because there 
are no valid truths inherent in biology and therefore a human being can create whatever

life he or she desires using his or her own individual consciousness. However, Sartre and Beauvoir also differ greatly on the idea of freedom in so far as men have the power to define, give, or deny freedom. As Kruks explains, "For although the 'eternal feminine' is humanly created and not natural, it is created by man (the male) through the situation he imposes on woman" (113). Beauvoir sums up this particular idea in The Second Sex: "History has shown us that men have always kept in their hands all concrete powers; since the earliest days of patriarchate they have thought best to keep women in a state of dependence; their codes of law have been set up against her; and thus she has been definitely established as the Other" (139). Woman is doomed to womanhood without many opportunities to create her own selfhood. Her otherness is necessary to man's norm, for in her absence, he fills the space.

Beauvoir goes on to expose man's ontological issue: "Once the subject seeks to assert himself, the Other, who limits and denies him, is none the less a necessity to him: he attains himself only through that reality which he is not, which is something other than himself" (139). He is what she isn't. His being is defined against her lack of being. The dominating patriarchal structure has much invested in the oppression of the other, not only politically and financially, but philosophically as well, for the very nature of the male self, according to Beauvoir, is contingent upon how irrelevant he can make his female counterpart. Beauvoir continues:

That is why man's life is never abundance and quietude; it is dearth and activity, it is struggle. Before him, man encounters Nature; he has some hold upon her, he endeavors to mold her to his desire. But she cannot fill his needs. Either she appears simply as a purely impersonal opposition, she is an obstacle and remains a stranger, or she submits passively to man's will and permits assimilation, so that he takes possession of her only through consuming her-that is, through 
destroying her. In both cases, he remains alone. (139)

Beauvoir differs from Sartre in that Sartre believes that each person has the responsibility to create his or her own life. Beauvoir disagrees on the grounds that oppressed subjects are not allowed the same opportunities to realize their own lives and therefore cannot be held accountable for their failures at creating authentic selves; how can a person want something that he or she does not even know exists? In Ethics of Ambiguity, Beauvoir reveals ideas of freedom that are markedly different from Sartre's. Beauvoir discusses the oppressed condition of the slave and how it may be necessary to help the slave understand his oppression and guide him to his freedom. She writes:

His submission is not enough to justify the tyranny which is imposed upon him. The slave is submissive when one has succeeded in mystifying him in such a way that his situation does not seem to him to be imposed by men, but to be immediately given by nature, by the gods, by the powers against whom revolt has no meaning; thus, he does not accept his condition through a resignation of his freedom since he cannot dream of any other; and in his relationships with his friends, for example, he can live as a free and moral man within this world where his ignorance has enclosed him. (85)

And this is the goal of the dominating patriarchy, Beauvoir would argue, for why would the dominating group do anything to disrupt its control? For the very nature of "revolt," Beauvoir argues, is to question the status quo and to eliminate the current mode of living so that a replacement can be instituted: "Revolt is not integrated into the harmonious development of the world; it does not wish to be integrated but rather to explode at the heart of the world and to break its continuity" (85). From the perspective of the patriarchy, an uprising that could potentially harm the interests of the hierarchy, traditionally dominated by male authority, must be avoided so that male authority can continue to force its own will and support its own interests. Beauvoir continues in Ethics of Ambiguity stating, "The conservative will argue from this that peace should not be 
disturbed; it is not necessary to give education to the people or comfort to the natives of the colonies; the "ringleaders" should be suppressed. . . there is no need to awaken the sleeper, for that would be to awaken him to unhappiness"(85). Beauvoir goes on to acknowledge that some slave owners who made this argument used their freed slaves as examples to back up their request to "leave well enough alone." The freed slaves, now thrust into a free world, lacked the skills necessary to navigate this world, and as a result, were frightened. Therefore, they wished to return to their masters, to the only world they understood. Beauvoir writes: "Certainly it is not a question of throwing men in spite of themselves, under the pretext of liberation, into a new world, one which they have not chosen, on which they have no grip" (85). Beauvoir sees a cruelty in forcing freedom onto a person who does not realize that he or she is a slave. Beauvoir believes that "the oppressor is lying if he claims that the oppressed positively wants oppression; he merely abstains from not wanting it because he is unaware of even the possibility of rejection" (87). She proposes that it is more important for emancipation to come from within the oppressed; the slave must first be enlightened, and then the will to freedom must come from within. She writes: "What must be done is to furnish the ignorant slave with the means of transcending his situation by means of revolt, to put an end to his ignorance" (86). Beauvoir acknowledges that those who are oppressed must fight the system in which they live in order to transcend their position and achieve freedom. The problem is that some oppressed people are unaware that they live within, and even support, a system that thrives on their misfortune. Therefore, the oppressed must first become aware of their plight, and then must make the decision to change: "All that an external action can propose is to put the oppressed in the presence of his freedom: then he will decide 
positively and freely. The fact is that he decides against oppression, and it is then that the movement of emancipation really begins" (87). But why should someone else care if a person is oppressed or not? Beauvoir answers this question: "To want existence, to want to disclose the world, and to want men to be free are one and the same will" (87).

The ruling structure needs to protect the society it built, for it benefits both politically and financially from this society. Therefore, the ruling structure will devise justifications to maintain the current situation. The common justifications for relegating women to the private sphere, making it socially inappropriate to engage in the public sphere, have been biological. Forcing inaccurate biological truths upon women's social selves has been a useful tool for the patriarchy to explain why women need to remain absent from political, financial, educational, and professional arenas. Beauvoir writes:

One of the ruses of oppression is to camouflage itself behind a natural situation since, after all, one cannot revolt against nature. When a conservative wishes to show that the proletariat is not oppressed, he declares that the present distribution of wealth is a natural fact and that there is thus no means of rejecting it; and doubtless he has a good case for proving that, strictly speaking, he is not stealing from the worker the product of his labor, since the word theft supposes social conventions. ... (83)

Using nature to justify oppression, to justify the exploitation of the other was an effective tactic used by the ruling structure to maintain supremacy within society while forcing women into submission; why would a woman want to break out of her god-given role? Kruks argues:

Woman is locked into immanence by the situation man inflicts upon her-and she is not necessarily responsible. As has been pointed out, a consistent Sartrean position would make woman responsible for herself, no matter how constrained her situation. But for de Beauvoir, although some women do comply with their oppression in "bad faith" this is not the main source of evil. For many, there is no "moral fault" because there is simply no possibility of choice. (114)

This is in sharp contrast to Sartre's notion of freedom as he believes that regardless of the 
situation a being finds him or herself in, it is up to that individual to create and interpret his or her own experiences.

Simone de Beauvoir and Virginia Woolf both recognized the power of patriarchy to define what "woman" is and what she is not. Their arguments in their polemical prose as well as within memoirs condemn male definitions as antiquated. Beauvoir claims: "One is not born, but rather, becomes a woman," and Woolf takes Orlando across generations and across sexes, as he wakes from his slumber one morning and realizes that he is a woman. The binary gender system is insufficient in creating truths for a self, and therefore, an argument for (An)Other gender must be put forth to settle the issues inherent in the binary gender system. The self must be defined by the individual, based on personal experiences and personal desires outside of societal pressures. Definitions forced upon the self from the outside cannot authentically communicate an individual('s) experience. Truth is realized within.

\section{Feminist Theory}

The standard modus operandi has always been to claim that women are limited in their possible societal roles because of certain facts about their nature determined by biological characteristics. The limits created in response to these biological characteristics have been treated as truths, or absolutes in society lending validity to the oppression of women specifically in the financial, professional, and educational spheres of society. Generations of patriarchal society determined that women should naturally be confined to the private sphere of life, tending to the home, the husband, and the offspring. Many feminist theorists have argued against this type of thinking, including Toril Moi, 
who argues against biological determinism in her work What is a Woman? and Other Essays and seeks to separate biology from societal norms.

Moi begins her discussion with looking back at the arguments used to keep women oppressed. She cites an 1883 publication by Johns Hopkins Biology Professor W. K. Brooks who claimed that "among the higher animals... the males are more variable than the females" and this is because "the male element is the originating and the female is the perpetuating factor; the ovum is conservative, the male cell progressive. Heredity or adherence to type is brought about by the ovum.; variation and adaptation through the male element." Moi explains that Brooks uses these biological claims to validate the gendered separation of duties in society:

For Brooks, it is obvious that social differences between the sexes are caused by their physiological differences. ... Moving on to intellectual differences between men and women, he claims that men's brains enable them to grasp the unknown: discoveries, science, the highest artistic and philosophical insights are reserved for them. Women's brains can deal with the known, the ordinary, and the everyday, keep track of traditions and social customs; in short, take care of everything that requires 'rational action without reflection.' Women preserve the old, men discover the new; 'the ovum is conservative, the male cell progressive.' (15-16)

Brooks, like so many others of his time, used biological claims to bolster specious theories about men and women in society. Women, because of their biological nature, were relegated to the private sphere while men, due to their biological nature as described by Brooks, were allowed to create a life that included political, economic, and educational successes.

Moi looks at the arguments set forth by Gayle Rubin in her 1975 essay "The Traffic in Women." According to Moi, Rubin sought "to develop conceptual tools that would combat sexism" (23):

[Feminists need to] build descriptions of the part of social life which is the locus 
of the oppression of women, of sexual minorities, and of certain aspects of human personality within individuals. I call that part of social life the "sex/gender system'... [ [which is] the set of arrangements by which a society transforms biological sexuality into products of human activity, and in which these transformed sexual needs are satisfied. (qtd. in Moi 23)

Rubin goes on to argue for her definitions of sex, gender, and identity. As Moi explains, "What interests Rubin is not sex, but gender. For her, the fundamental meaning of gender is oppressive social norms: gender is the oppressive result of a social production process. On the structural level, Rubin takes sex to mean biological sexual differences and gender to mean the oppressive social norms brought to bear on these differences (Moi 24). While Moi agrees with Rubin that there is a problem with using sex to validate oppressive social structures, she also believes there is more to the argument and points out the inherent gaps in the notion of sex as merely chromosomal and gender as purely social. Moi believes that these gaps render the idea of sex completely useless and unimportant and feels that this is false: "The philosophical and political drawbacks of this reintroduction of the body/mind distinction are only too apparent. Entirely divorced from the mind, the body is perceived as a mere object, subject to the mind's decisions, a blank slate on which gender writes it script. In this idealist view, the body (nature) is entirely subordinated to the mind" (Moi 27). Moi believes, like so many other feminist theorists, that the mind/body, sex/gender argument is not this simple. While it is inaccurate to construct a notion of female gender based upon the biological functions of the body, the body can be a valid consideration when discussing individual experiences. Moi states:

My argument is not that there is nothing in nature (i.e. that we have to deny the existence of biological facts), but whatever there is in nature whatever facts we may discover about human biology and genetic structure) is never going to justify any particular social arrangement. Even if we assume that there are only two sexes, this is no reason not to construct a society with three or five or ten genders, or indeed without gender at all... [We] can never get rid of sex, but we can 
certainly hope to produce societies that either multiply or eliminate gender. (114)

Moi believes that the intentional divide between the body and the mind ignores a potentially useful way of viewing the body. For while there can be distinction between what the mind desires as opposed to the desires of the body, there are many instances where the body experiences and the mind interprets. Moi draws upon both Merleau-Ponty and Beauvoir:

What Merleau-Ponty and Beauvoir show is that the relationship between the body and subjectivity is neither necessary nor arbitrary, but contingent. . . . [The] body is fundamentally ambiguous, neither simply subject to the natural laws of cause and effect that science might uncover, nor simply an effect of consciousness (or of power, ideology, or regulatory discourses for that matter). (114)

Human beings are immanently more complex than the biology of which they are compiled. A human male or a human female cannot be reduced to cells. Human beings are both biology and subjective experience. As Moi states:

The human body is neither sex nor gender, neither nature nor culture. To say that my subjectivity stands in contingent relationship to my body is to acknowledge that my body will significantly influence both what society-others-make of me, and the kind of choices I will make in response to the Other's image of me, but it is also to acknowledge that no specific form of subjectivity is ever a necessary consequence of having a particular body. (114)

It cannot be denied that the way human beings view the self is filtered through predetermined societal lenses, and herein lies the problem. These predetermined lenses have been predominantly male-created and male-dominated, and therefore, women have always been viewed and defined through male (ab)norms. These (ab)norms have been set up to specify which roles men and women are allowed or expected to fulfill within society, or even outside of society, as women have traditionally been relegated to the private sphere.

The ideas posited by Moi in her essay are also taken up by Luce Irigaray as well. 
As Irigaray states in her essay "This Sex Which Is Not One," "Female sexuality has always been theorized within masculine parameters"(23). It is Irigaray's contention that phallocentric views of the world continuously position women as other, for women lack the "noble phallic organ" of the male and in actuality are considered literally and figuratively " a hole-envelope that serves to sheath and massage the penis in intercourse: a non-sex, or a masculine organ turned back upon itself, self embracing"(23). The image of the woman set forth by Irigaray defines her as nothing more than a non-male, entirely determined by his presence. Irigaray continues, claiming, "Woman, in this sexual imaginary, is only a more or less obliging prop for the enactment of man's fantasies. That she may find pleasure there in that role, by proxy, is possible, even certain. But such pleasure is above all a masochistic prostitution of her body to a desire that is not her own, and it leaves her in a familiar state of dependency upon a man" (25). Irigaray argues that society does not provide a method for women to properly view or consider the self without the utilization of the masculine as the norm.

Specifically, where biology is concerned, women are considered absent, whereas the male is very present. The sex organs, or lack of sex organs in the case of the "inverted" female, creates yet another sphere of life where women are ignored or thrust onto the margins of society. Her lack of sexual biology is considered a valid factor when arguing for a woman's place in society. She is the receiver, and the male is the giver. She must take whatever he sees fit to give her. We are reminded of Moi's discussion of Brooks, who claimed "the ovum is conservative, the male cell progressive" and this claim was the basis for Brooks' argument of men and women's proper positions and suitable endeavors in society. The ovum lies in wait for the sperm to enter it. The perceived 
passivity of female biology was considered justification for the oppression of women in society and grounds for denying women access to political, educational, and professional opportunities, for these areas of life are considered progressive and aggressive, two characteristics that were deemed unsuitable for the passive female make-up. However, Irigaray argues that women are not absent; on the contrary they are everywhere in their sexuality and in their sexual organs. She writes, "But woman has sex organs more or less everywhere. She finds pleasure almost anywhere. Even if we refrain from invoking the hystericization of her entire body, the geography of her pleasure is more diversified, more multiple in its differences, more complex, more subtle, than is commonly imagined-in an imaginary rather too narrowly focused on sameness"(28).

Irigaray discusses the female (in)ability to define herself and her sexuality in such a hostile environment where male desire is considered dominant. Irigaray argues that a woman's sexuality needs to be considered for its multiplicity rather than its perceived absence but realizes that there are few ways to discuss the multiplicity of female sexuality using a male-dominated language system:

Must this multiplicity of female desire and female language be understood as shards, scattered remnants of a violated sexuality? A sexuality denied? The question has no simple answer. The rejection, the exclusion of the female imaginary certainly puts woman in the position of experiencing herself only fragmentarily, in the little-structured margins of a dominant ideology, as waste, or excess, what is left of a mirror invested by the (masculine) subject to reflect himself, to copy himself. (30)

Irigaray's notion of the mirror that is used to reflect the masculine subject reminds one of Woolf's claim that women are responsible for reflecting the image of a man: "Women have served all these centuries as looking-glasses possessing the magic and delicious power of reflecting the figure of man at twice its natural size"(AROO 35).The female 
reproductive organs are used by the male to reproduce or reflect his image via procreation. In this case, female sexuality is reduced to maternity, rather than individual sexual experience and pleasure. But how can this one-sided, male construction of female sexuality and experience be corrected? In another essay, Irigaray discusses the lack of female expression and claims that there is indeed an absence in the ability to express female sexuality and experience in a male-dominated language system.

In her essay, "When Our Lips Speak Together," Irigaray speaks to women about the difficulties of discussing the self in any sort of female terms because traditionally women are forced to define themselves against male (counter)parts. As in the previous essay where Irigaray argues that women are defined by the absence of a penis, this essay argues that women lack a language through which they can define themselves authentically, without using any type of male norm as a ciphering mechanism. Irigaray argues, "If we keep on speaking the same language together, we're going to reproduce the same history" (205). The cyclical nature of female oppression is in some ways perpetuated by the language used to describe human experience. Since all things social have been filtered through male domination and male interests, including female experiences, then to use the same traditional language that has always been used will result in little change. If women are unable to voice their experiences or desires through a language that allows for authentic female expression, then women will always be defined in male terms. Irigaray writes,

Absent from ourselves: we'll be spoken machines, speaking machines. Enveloped in proper skins, but not our own. Withdrawn into proper names, violated by them. Not yours, not mine. We don't have any. We change our names as men exchange us, as they use us up. It would be frivolous of us, exchanged by them, to be so changeable. (205) 
A shift in not only how women are viewed, but in how women are defined, or how they define themselves, is necessary in order for change to occur across society, across borders, and across time and history. This particular selection from Irigaray also brings up an issue of accountability, for women too play a role in their own oppression, accepting the rules of patriarchy and pressuring other women to accept those rules as well. Irigaray warns women against abiding by societal rules not of their making, and certainly not designed to serve female interests. Every option a woman has to define herself is imbedded in male tradition. Irigaray presents a challenge to women: "Come out of their language. Try to go back through the names they've given you.... You stay here and you won't be absorbed into familiar scenes, worn-out phrases, routine gestures. Into bodies already encoded within a system. Try to pay attention to yourself. To me. Without letting convention, or habit, distract you" (206). Irigaray's challenge to women is to actively seek other ways, outside of the societal norms dictated by patriarchal interests, of viewing the self. This is reminiscent of Virginia Woolf's Three Guineas in which she warns women as they enter the public sphere not merely to adopt the male-dominated traditions of society, but rather to create a society of outsiders so than women do not fall prey to the corrupt nature of male-dominated society. Instead, Woolf believes that women should remain true to an atmosphere of change rather that a melding into the conventional. Woolf writes:

If name it must have, it could be called the Outsider's Society... . It would consist of educated men's daughters working in their own class- - how indeed can they work in any other?- - and by their own methods for liberty, equality and peace. Their first duty, to which they would bind themselves not by oath, for oaths and ceremonies have no part in a society which must be anonymous and elastic before everything, would be not to fight with arms. (TG 106)

Society, as Woolf claims, must be anonymous and elastic in order to be free and equal. 
Does this include anonymity of gender? For gender, or the mistaken identity of gender for sex as discussed by Moi and Irigaray, is a primary source of validation to the status quo for keeping women out of the public sphere and away from access to a useful education, and a chance at professional and financial independence. Michèle Le Doeuff in her essay "Women and Philosophy" takes up this issue as she describes the condition of women in society and on philosophy, and what can be done to rectify injustices. She writes:

'Woman', as well as having been from time immemorial alienated, beaten and deprived of political, sexual, and social rights and legal identity, last and least of all found herself forbidden all access to philosophy. So far as a classification of the rights denied to women is concerned, it is clear that there is a disproportion between the right to have one's own salary or to decide one's sexual destiny, and that to philosophize, and that disproportion can only leave the right to philosophizing foundering in the anecdotal. (181)

Le Doeuff describes not just a social strangling of women, but an intellectual one as well, for women have traditionally been denied the right to explore the field of philosophical thought. And while she does recognize that there have been a few women who excelled in this field, there have only been a few. But Le Doeuff does not want to succumb to the seductive nature of complaining about woman's lot in society like so many other feminist positions. She claims that "this kind of discourse. ... can only be maintained by recourse to the ploy of distraction, avoiding analysis of the concrete modalities of oppression"

(181). She also discusses feminism of difference. She writes:

Some women say: "We have been forbidden access to the philosophic realm; rightly understood, this is something positive, and we do not demand and such access; this discourse is riddled with masculine values, and women should not be concerned with it; they must seek their specificity, their own discourse, instead of wanting to share masculine privileges." (182)

While Le Doeuff does not completely discount all of what a feminism of difference has 
to offer, she warns that to succumb completely to this thinking would be to participate in a patriarchal ideology that has been long used to oppress women: "We must recognize that this kind of feminism may do the opposite of what it claims, that it may be misled by schemas produced by the very structures against which it is protesting" (182). Le Doeuff believes that it is through the utilization of philosophical thinking that the masculine/feminine division can be rectified or at least analyzed and redefined even though some problems with this division have been created in part by philosophy, a field dominated by traditional patriarchal structures.

While Le Doeuff is concerned with how women utilize philosophy to redefine their place in the world, Irigaray too is conflicted with how to make a change in the way women express themselves. How can women affect what is? Irigaray writes in "When Our Lips Speak Together," "But how can I put 'I love you' differently? That still means yielding to their language. They've left us only lacks, deficiencies, to designate ourselves. They've left us their negative(s). We ought to be - that's already going too farindifferent" (207). Like Woolf's "Outsiders Society," Irigaray challenges women to make a conscious effort to change all the while being careful not to meld women's needs into men's. She writes: "When you stir, you disturb their order. You upset everything. You break the circle of their habits, the circularity of their exchanges, their knowledge, their desire. Their world" (207). In order to disturb the status quo, women must cause change. But of course, this will be resisted for it is threatening to patriarchal control:

Adapting yourself to whatever need they have, or don't have, for the presence of their own image. One step, or two. No more. No exuberance. No turbulence. Otherwise you'll smash everything. The ice, the mirror. Their earth, their mother. And what about your life? You must pretend to receive it from them. You're an indifferent, insignificant little receptacle, subject to their demands alone. (208) 
In this passage, Irigaray not only points out the injustices of women's position in relationship to men, but she also points out women's complacency in upholding the oppressive roles prescribed to them by men and their society. Like Woolf, Irigaray places some blame upon women for their complicity in their own oppression, but reveals to them that they do have some power to disturb patriarchal domination. She believes that if women utilize their multiplicity and polyvocality as individual sexual beings as well as a group with common characteristics in both oppression and freedom, then change in society could occur. She writes,

Between our lips, yours and mine, several voices, several ways of speaking resound endlessly, back and forth. One is never separable from the other. You/I: we are always several at once. And how could one dominate the other? Impose her voice, her tone, her meaning? One cannot be distinguished from the other; which does not mean they are indistinct. (209)

One is reminded of Simone de Beauvoir who claims that women refuse to see themselves as an identifiable group. Rather, women are defined by the men they associate with. If a man is upper class, then so too are his wife and daughter. However, if a woman belongs to a minority subset, defined by race for example, she does not identify with women as a whole group but rather with her racial set instead. Beauvoir writes:

The reason for this is that women lack concrete means for organizing themselves into a unit which can stand face to face with the correlative unit. They have no past, no history, no religion of their own; and they have no such solidarity of work and interest as that of the proletariat.... They lived dispersed among the males, attached through residence, housework, economic condition, and social standing to certain men-fathers and husbands-more firmly than they are to women. (SS $\mathrm{xxv})$

The lack of female history and community in culture is an issue Woolf also takes up in Three Guineas. In particular, Beauvoir's last comment reminds one of Woolf's contempt for women being defined as daughters of educated men in Three Guineas: 
Our ideology is still so inveterately anthropocentric that it has been necessary to coin this clumsy term - educated man's daughter - to describe the class whose fathers have been educated at public schools and universities. Obviously, if the term "bourgeois" fits her brother, it is grossly incorrect to use it of one who differs so profoundly in the two prime characteristics of the bourgeoisie - capital and environment. (146)

When women can bring their voices together, or as Irigaray puts it, "When our lips speak together," then woman can begin to cause an upheaval in society.

Like Luce Irigaray, Julia Kristeva, in her essay "Woman Can Never Be Defined" also discusses the oppression of Woman as she lacks the language and the power to articulate her experiences and define herself. Kristeva argues that to use the term "woman" to describe what society understands as woman is wrong. She states,

The belief that "one is a woman" is almost as absurd and obscurantist as the belief that "one is a man." I say "almost" because there are still many goals which women can achieve: freedom of abortion and contraception, day-care centers for children, equality on the job, etc. Therefore, we must use "we are women" as an advertisement or slogan for our demands. (137)

Kristeva sees inadequacies in how women are defined in such limited ways. Like Irigaray, Kristeva points out the "absences" or the considerable "lack" of ways women can own their experiences. She continues:

On a deeper level, however, a woman cannot "be"; it is something which does not even belong in the order of being. It follows that a feminist practice can only be a negative, at odds with what already exists so that we may say "that's not it" and "that's still not it." In "woman" I see something that cannot be represented, something that is not said, something above and beyond nomenclatures and ideologies. (138)

Kristeva seems to be referring to the idea that women have had to define themselves against what they are not: men. In this mode of defining and redefining, the common denominator is negativity; she is always lacking and that is how she is (un)known.

Therefore, how can a negative, or a non-being, be a being? This becomes problematic for 
women who seek to define what is uniquely woman outside of the male norm.

In another essay, "About Chinese Women," Kristeva continues this discussion of absence or lack of a female voice in patriarchal society and argues that that which is unspoken is just as present as that which is, and it is the unspoken that has always been classified as "woman":

There is no time without speech. Therefore, there is no time without the father. That, incidentally, is what the Father is: sign and time. It is understandable, then, that what the father doesn't say about the unspoken, what sign and time repress in the drives, appears as their truth (if there is no 'absolute', what is truth, if not the unspoken of the spoken?) and that this truth can be imagined only as a woman. (153)

What is unspoken is defined against what is spoken; it is the blank margins of the full page. Therefore, the female voice, always silenced or absent from the pages, is defined against the male voice which is always spoken or written. Woman is defined against what $H e$ is and therefore defined by what She is not, or her lack of something. Kristeva goes on to encourage a linguistic revolution, or a consciousness of that which is unspoken or silenced, and yet at the same time she negates the idea of the term revolutionary as it has always been defined in patriarchal-societal-political terms:

But let us not take the role of Revolutionary either, whether male or female: let us on the contrary refuse all roles to summon this 'truth' situated outside time, a truth that is neither true nor false, that cannot be fitted in to the order of speech and social symbolism, that is an echo of jouissance, of our mad words, or our pregnancies. But how can we do this? By listening; by recognizing the unspoken in all discourse, however Revolutionary, by emphasizing at each point whatever remains unsatisfied, repressed, new, eccentric, incomprehensible, that which disturbs the mutual understanding of the established powers. (156)

Kristeva argues for the vocality of those who have been silenced. She believes that it is possible to recover the voices that have never been spoken merely by paying attention to what has not been said against what has been vocalized or written. This is useful in the 
recovery of a women's history, both social and literary, for there is language in the absence of language and therefore there is meaning in absence.

Like Kristeva, Hélène Cixous finds the task of defining women difficult and believes that even using the term "woman" is problematic. In her essay "The Laugh of the Medusa," she deems it necessary to pose her own filtered definition of the term "woman" so that she can present her argument. She clarifies what she does and does not mean by using the term woman:

When I say "woman," I'm speaking of woman in her inevitable struggle against conventional man; and of a universal woman subject who must bring women to their senses and to their meaning in history. But first it must be said that in spite of the enormity of the repression that has kept them in the "dark"--that dark which people have been trying to make them accept as their attribute-there is, at this time, no general woman, no one typical woman. (245)

Cixous sees great variation among those deemed "woman" and believes that to classify certain people strictly as "women" is inaccurate and short sighted. Cixous believes that women must position themselves in a better place in society, and, like Irigaray, she feels that women have some power with which to wield their will. She writes, inciting women to "write the body," "Woman must write herself: must write about women and bring women to writing, from which they have been driven away as violently as from their bodies - for the same reasons, by the same law, with the same fatal goal. Woman must put herself into the text—as into the world and into history—by her own movement" (245) This passage indicates Cixous' belief that this is an endeavor that women should be able to fulfill. A woman's experience of her own body is not something that can be taken from her by a man. He can experience her body for himself, and he can force her to allow him to experience her body, but she has the ability to interpret her experiences as she likes. Cixous writes: 
To write: An act which will not only "realize" the decensored relation of woman to her sexuality, to her womanly being, giving her access to her native strength; it will give her back her goods, her pleasures, her organs, her immense bodily territories which have been kept under seal; it will tear her away from the superegoized structure in which she has always occupied the place reserved for the guilty.... (250)

Patriarchal society has tried to hold dominion over women's bodies and voices, and for the most part was quite successful in silencing the expressions of women's experiences, hindering women from "writing the body" through a male-dominated medium:

Far more extensively and repressively than is ever suspected or admitted, writing has been run by a libidinal and cultural-hence political, typically masculineeconomy; that this is a locus where the repression of women has been perpetuated, over and over, more or less consciously, and in a manner that's frightening since it's often hidden or adorned with the mystifying charms of fiction; that this locus has grossly exaggerated all the signs of sexual oppression. . . where woman has never her turn to speak - this being all the more serious and unpardonable in that writing is precisely the very possibility of change, the space that can serve as a springboard for subversive thought, the precursory movement of a transformation of social and cultural structures. (249)

The literary tradition has kept women's voices and experiences in the margins, and Cixous claims that it is through the art and the act of writing that society and culture can change. However, if women have no access to writing, then they have no access to the possibility of change. Cixous claims that women can take repossession of their own bodies and utilize their voices, both verbal and written, to (re)define and (re)interpret their life experiences if they participate in the literary world in which they can "write the body" from their own perspectives.

But if it were that easy, wouldn't this task already be fulfilled? While Cixous does state that "the future must no longer be determined by the past," she also admits "I do not deny that effects of the past are still with us. But I refuse to strengthen them by repeating them, to confer upon them an irremovability the equivalent of destiny, to confuse the 
biological and the cultural" (245). Cixous believes that while women have fallen victim to the circumstances of the past dictated by patriarchal values, women do in fact have some power in changing their own future. Cixous, like so many other feminist theorists, sees the injustice in using the antiquated biological characteristics as justification for cultural or social oppression.

Cixous believes that the limited roles of women in society stem from their shame to do anything outside or "above" their socially prescribed roles. Women who privately acted in "selfishly" sexual or intellectual ways did so out of shame and fear, for they believed that it was wrong to challenge social prescriptons, and they therefore hid their accomplishments. As a consequence, numerous examples of female sexual or intellectual activity are not widely known, and each individual woman feels alone in her "shameful" actions. Cixous poses a call to action, encouraging women to write the body as if "woman" were a genre in itself. Cixous describes women who talk to her about their early experiences with sexuality:

I have been amazed more than once by a description a woman gave me of a world all her own which she had been secretly haunting since early childhood. A world of searching, the elaboration of a knowledge, on the basis of a systematic experimentation with the bodily functions, a passionate and precise interrogation of her erotogeneity. (246)

Cixous goes on to say that she wishes these different women would write their experiences so that other women, having similar experiences, could relate, exclaiming "I, too, overflow; my desires have invented new desires, my body knows unheard-of songs" (246). Reminiscent of Irigaray's discussion of the polyvocality she believes women possess, Cixous desires that women share their voices and experiences. She writes: And I, too, said nothing, showed nothing; I didn't open my mouth, I didn't repaint my half of the world. I was ashamed. I was afraid, and I swallowed my shame and 
my fear. I said to myself: You are mad! What's the meaning of these waves, these floods, these outbursts?" Where is the ebullient, infinite woman who, immersed as she was in her naiveté, kept in the dark about herself, led into self-disdain by the great arm of parental-conjugal phallocentrism, hasn't been ashamed of her strength? Who, surprised and horrified by the fantastic tumults of her drives (for she was made to believe that a well-adjusted normal woman has a ... divine composure), hasn't accused herself of being a monster? Who, feeling a funny desire stirring inside her (to sing, to write, to dare to speak, in short, to bring about something new), hasn't thought she was sick? (246)

Cixous' call to action is reminiscent of Woolf's sentiments in "A Sketch of the Past," "I make it real by putting it into words" (MB 72). Women have had to silence their individual voice so as to conform to their roles within society. And if they desired something more, they were conditioned to feel shame for having those feelings, even if those feelings were never expressed. Just to have those thoughts made her feel like a monster. Cixous believes that women must use their voices to show that there is nothing odd about their desires, in fact, desire is what women have in common. She wants women to write! Write woman! But they haven't, and she confronts this silence, both intellectually and sexually:

I know why you haven't written. . . Because writing is at once too high, too great for you, it's reserved for the great-that is for "great men"; and it's silly." Besides, you've written a little, but in secret. And it wasn't good, because it was in secret, and because you punished yourself for writing, ... as when we would masturbate in secret, not to go further. . . just enough to take the edge off. And as soon as we come, we go and make ourselves feel guilty. (Cixous 246-7)

The mind/body duality that Cixous creates with her discussion of a woman's creativity as she attempts to write, and her sexuality as she attempts to sexually satisfy herself as an individual, brings up the argument again that a human female, as well as a human male, is much more than the cells from which she or he are made. Rather, her being stems more from what she makes of her cells. The pressures from society for a woman to conform to what society desires her to be are great and difficult to refute. However, Cixous sees 
women as having the capacity to implement their voices through their writing. She states, "It is time to liberate the New Woman from the Old by coming to know her-by loving her for getting by, for getting beyond the Old without delay, by going out ahead of what the New Woman will be, as an arrow quits the bow with a movement that gathers and separates the vibrations musically, in order to be more than herself" (249). Again, Cixous does not deny that the history of writing offers few female voices. She admits that the enormous machine constructed and operated by the patriarchy has been designed to squelch woman's creativity and freedom in the world. This machine, which has formed history, she writes, "has been one with the phallocentric tradition. It is indeed that same self-admiring, self-stimulating, self-congratulatory phallocentrism" (249). And why wouldn't it be? Why would the patriarchy develop a system that did not uphold its own values and serve its own interests? However, as Cixous points out, there must have been a few problems in the system, "for there have been failures-and if it weren't for them, I wouldn't be writing (I-woman, escapee)-in that enormous machine that has been operating and turning out its "truth" for centuries" (249). Cixous discusses the role of a poet in the "escape" of a woman from the strongholds of tradition, for the poet can imagine a woman "who would hold out against oppression" and become "superb, equal" in society (249). Women must "write the body" and take back the voice and the experiences that have been denied them by the male dominated traditions of society because "your body must be heard" (250). Cixous writes that "she must write herself, because this is the invention of a new insurgent writing which, when the moment of her liberation has come, will allow her to carry out the indispensable ruptures and transformations in her history" (250). What will come of women "writing the body" is 
the recapturing of their voices:

a)Individually. By writing her self, woman will return to the body which has been more than confiscated from her, which has been turned into the uncanny stranger on display.... Censor the body and you censor breath and speech at the same time.... b) An act that will also be marked by woman's seizing the occasion to speak, hence her shattering entry into history, which has always been based on her suppression. To write and thus to forge for herself the anti-logos weapon. To become at will the taker and initiator, for her own right, in every symbolic system, in every political process. It is time for women to start scoring their feats in written and oral language. (250-1)

Cixous is concerned with a woman's ability to express her own experiences in society both in written and spoken form. This power has long been kept from her in patriarchal societies where a woman's experiences have always been filtered through maledominated language traditions, including literary traditions. Cixous believes that if women write their own experiences, forcing their voices to be heard, then the social structure will change, for literature reflects society and society can be changed by literature.

In her other work The Newly Born Woman, Cixous, along with Catherine Clément, discusses the formulation of the hierarchal nature of society and the male and female roles as dictated by the rules of sexual difference within that hierarchy:

We see that "victory" always comes down to the same thing: things get hierarchal. Organization by hierarchy makes all conceptual organization subject to man. Male privilege, shown in the opposition between activity and passivity, which he uses to sustain himself. Traditionally, the question of sexual difference is treated by coupling it with the opposition, activity/passivity. (64)

Looking back at Moi's discussion of Brooks, we can see some similarities in this discussion of activity/passivity. Woman is assuming the passive role in society allows for the active male to protect his own interests within the society he has created. Cixous goes on to discuss that when it comes to who/what a woman is, the ontological dilemma arises 
and is not easily satisfied. Whenever there is a question of authority in the public or the private sphere, the designated realm of the woman, the man/husband/father is still deemed the authority in society as well as the head of the household. As Cixous and Clément argue, "Either woman is passive or she does not exist. What is left of her is unthinkable, unthought" (64). Utilizing a fairy tale scenario, Cixous and Clément depict a woman's passivity to the extent that she cannot act unless stimulated by the active male. They write:

Beauties slept in their woods, waiting for princes to come and wake them up. In their beds, in their glass coffins, in their childhood forests like dead woman. Beautiful, but passive; hence desirable: all mysteries emanate from them. It is men who like to play dolls. As we have known since Pygmalion. Their old dream: to be god the mother. The best mother, the second mother, the one who gives the second birth. ... She sleeps, she is intact, eternal, absolutely powerless. ... However, she is breathing. Just enough life-and not too much. ... (66)

The woman lies in wait, unable to act until the male subject inaugurates action. Her life force is just enough to keep her from being dead; her passivity is so great that she does not move unless he moves her, like a child manipulating the arms and legs of a doll. She is at his mercy, physically, mentally, and of course, socially. After she has been granted consciousness as the male takes what he desires from her physically, she has not achieved much more than she had when she was comatose in the private sphere, here depicted by a glass coffin - able to see the world, but unable to join in. And after the awakening takes place, who has benefited? Whose desires have been fulfilled? The man. The woman must wait for her next appointment, for she is at the mercy of the hierarchal structure in which she is always subject to male authority.

The philosophical and theoretical framework of existentialism, phenomenology, and feminist theory are useful when looking at how Woolf and Beauvoir were working 
within their respective times to (re)define a woman's place in society. The way women were viewed as little more than beings with reproductive capabilities produced a hostile environment for women as they sought to expand their options in society. However, the World Wars changed society for both men and women, and many struggled to hold on to an antiquated and obsolete mode of existing in society, but that world no longer existed. However, the shake-up of traditional society benefited women who had always been pushed aside while men continued to rule society, especially under the guise of a natural mandate suggesting that women belonged at home because of their biological nature, and men belong in the public sphere due to their nature as well. 
Notes

${ }^{1}$ Several critics analyze the female body as it is "used" in society. For instance, Toril Moi argues against biological determinism in her work What is a Woman? and Other Essays, and Julia Kristeva discusses the repression of Woman as she lacks the language to discuss her experiences in "Woman can never be defined" in New French Feminisms. Hélène Cixous breaks down the battle between the sexes into the categories of subject and object in The Newly Born Woman and discusses the necessity of changing from standard norms to something uniquely woman in "The Laugh of the Medusa." Luce Irigaray calls into question the phallocentric absence in women as she distinguishes between man/one and woman/other in her essays "When our lips speak together," and "This Sex Which Is Not One." Michele Le Doeuff discusses women's participation in philosophy in her essay "Women and Philosophy." 


\section{CHAPTER FOUR: \\ MRS. DALLOWAY IS THE SECOND SEX: RE-READING WOOLF'S WOMEN THROUGH THE LENS OF BEAUVOIR'S THE SECOND SEX}

In order to bring several of the themes from the previous sections to life, examples will be drawn from Woolf's fictional works, Mrs. Dalloway in particular, and re-reading the characters using Beauvoir's The Second Sex in order to analyze the definition of the traditional woman in accordance with each writer's ideas and experiences. This chapter is not comparing genres but rather re-visiting Woolf's fictional works through the lens of Beauvoir's The Second Sex, for Beauvoir clearly describes the traditional role of women dictated by patriarchal domination. For example, Woolf's Clarissa Dalloway's loss of identity and her struggle to regain the self can be analyzed through Beauvoir's discussions of the young girl, versus the married woman, versus the socialite. So too will the political naiveté and powerlessness of women during the First World War from 1914-1918, the interwar years, and World War II from 1939-1945 be discussed using these two examples as well, for both Clarissa Dalloway and the women discussed in The Second Sex are political byproducts of their marriages and of their domestic lives:

But she has no other job than to maintain and provide for life in pure and unvarying generality; she perpetuates the species without change, she ensures the even rhythm of the days and the continuity of the home, seeing to it that the doors are locked. But she is allowed no direct influence upon the future nor upon the world; she reaches out beyond herself toward the social group only through her husband as intermediary. (SS 430) 
Having no power to instill meaningful change within society is the direct result of the political, financial, and educational domination of women during the war years during which both Woolf and Beauvoir lived. The lack of female control and participation in society is reflected in the life and thoughts of Clarissa Dalloway as she goes about her day, arranging her soirée, searching for the self she once possessed but somehow lost through the years of marriage and the details of party planning. Clarissa has no measurable impact upon society, the war, or the death of Septimus Smith. Her only control is over the gathering, and even that is getting out of hand as one of her guests dares to bring death to her party, threatening to disrupt the atmosphere she so painstakingly attempted to create.

Death came to so many people during the First World War and then World War Two, and trying to recover from those devastating times was difficult, making it almost impossible to return to the traditional ways of living life. Men and women both struggled to redefine themselves within the context of a new world, and the anxieties they felt over how to manage their new roles within society were greatly reflected in the writing of the modern period. It was difficult to express the emotions felt over the wars and the changes they brought about in people's daily lives and traditional roles. According to Karen DeMeester in "Postwar recovery in Mrs. Dalloway," trying to find ways to define a person in the aftermath of war was a great concern as soldiers came home traumatized to families who were equally traumatized by the war and its effects. She writes:

Trauma and recovery, particularly in the case of war, are simultaneously individual and communal experiences. The community that places the soldier in combat, like the soldier himself, can either change and create a new identity that reflects the experiences of war, or stagnate in an attempt to reestablish a prewar identity that gave rise to the conflict in the first place. (84) 
After the First World War ended, the patriarchal culture in both France and Great Britain wished to return to prewar days in which men and women maintained traditional roles within the public and private spheres respectively, and also desired to leave the atrocities of war safely in the past, making it difficult for those who suffered trauma from the war, both men and women, to express their new identities in a changing world. This is an idea that Woolf focuses on in Mrs. Dalloway as the governing class is eager to forget the past and thus forget traumatized soldiers like Septimus Smith who threaten to destroy the illusion of peace with his emotional instability. DeMeester continues, discussing the individual's need to express personal trauma to those who will listen and relate:

In contemporary society, the process of communalization [is]- "being able safely to tell the story [of the trauma] to someone who is listening and who can be trusted to retell it truthfully to others in the community"... . Communalization functions as a means of self-transcendent giving and a conduit through which meaning and purpose can emerge from the trauma. (85)

The need to tell the story and to express the emotions and anxieties created from the war were very much a part of healing for the individual and necessary in order for the individual to move forward, away from the crisis. However, digging up all the negative happenings from the war was not a practice in which the dominate society wished to participate as illustrated by Woolf's Sir William Bradshaw in his treatment of the traumatized Septimus Smith. DeMeester explains:

The safety of the social order depends, however, on that brutal monster remaining quiet and is inevitably threatened by stories extolling its virtues. Powerful forces in the community, defenders of the social order like Sir William Bradshaw, fight to repress the story and appropriate or codify it to affirm rather than challenge the established order and the beliefs and conventions that secure it. ... "If survivors retain control over the interpretation of their trauma, they can sometimes force a shift in the social and political structure. If the dominant culture manages to appropriate the trauma and can codify it in its own terms, the status quo will remain unchanged." (85) 
The patriarchal social order is concerned with protecting its own interests and therefore does not want change within the culture; both French and British culture has been designed to enhance the patriarchal agenda. To allow major change to occur within society would be to allow the fall of patriarchal domination, and that was not an occurrence that neither French nor British society was going to allow to happen easily. Therefore, there is a struggle in society for control, and both Woolf and Beauvoir write about the struggles especially in regard to gendered roles for both men and women in the public and private spheres. Re-reading Woolf's characters through the historical lens of Simone de Beauvoir's The Second Sex allows an understanding of the difficulties for women to break free from their socially prescribed roles, the consequences for doing so, and the possibilities for the New Woman.

\section{The Tradition of Social Life: "Remember my party tonight!"}

Simone de Beauvoir dedicates an entire chapter of The Second Sex to social life, as it was one of the primary domains of the traditional woman. Opening the private home to visitors and guests was a way for the lady of the house to be exposed to the outside world, and was a way for her to interact with other adults besides her husband. In addition to welcoming guests into her home, the traditional woman ventured into the homes of her peers as they opened their own doors for parties and social gatherings of sorts. As Beauvoir writes in her chapter "Social Life,"

The family is not a closed community: its isolation is qualified by communications set up with other social units.; the home is not merely an "interior" within which the couple is shut away; it is also the expression of that couple's standard of life, its financial status, its taste, and thus the home must needs be on view to other people. (SS 528) 
A couple's ability to flaunt their home and to possess the financial resources to entertain was an important part of maintaining appearances. The ability to hold dinner parties was a sign of a couple's wealth and social standing, and therefore was a necessary part of social life. And while the joyous atmosphere of a party can seem uplifting and pleasurable, it was actually, according to Beauvoir, unfortunate that a woman was allowed very little control over anything else in her life. The details of a good social life, including parties, teas, gossip, decorations, food, and party attire, are some of the few things a woman could control and in which she can take some pride: "It is essentially the woman's part to direct this social life" (SS 528). Outside of these social functions, however, she is otherwise powerless, for the traditional woman still possessed little if any political, educational, or financial power.

The image of social life and of the woman responsible for that life as described by Simone de Beauvoir is embodied in the characters of Virginia Woolf. Woolf's most famous socialite is Clarissa Dalloway, as she is portrayed in the novel Mrs. Dalloway, but also as she is depicted in the shorter fictional works, "Mrs. Dalloway in Bond Street" and "The Introduction."

Mrs. Dalloway begins with an opening line referring to Clarissa's party that evening: "Mrs. Dalloway said she would buy the flowers herself" (3). Almost a character in itself, the party is present throughout the novel as Clarissa and her house-workers prepare for her guests. The fact that Clarissa, an upper-class woman of leisure, immerses herself in the party details indicates how important the event is to her. She spends her time tending to items such as the flowers, her dress, the silver, linens, crystal, and the housekeeping. She takes great pride in all of these small preparations for her party: 
Strange she thought, pausing on the landing, and assembling that diamond shape, that single person, strange how a mistress knows the very moment, the very temper of her house! Faint sounds rose in spirals up the well of the stairs; the swish of a mop; tapping; knocking; a loudness when the front door opened; a voice repeating a message in the basement; the chink of silver in a tray; clean silver for the party. All was for the party. (37)

Paying attention to the smallest details, and even tending to a few chores herself proves

Clarissa's dedication to her role and to the success of her event. According to Karen

DeMeester in "Postwar recovery in Mrs. Dalloway":

Clarissa's party is modernist in form, insofar as it remains personal, internal, and private. One gets the sense that the order, the pattern that emerges at her party is not organic but cultivated. Clarissa envisions the components-the people, the flowers, the china - converging, crystallizing into an intricate pattern of perfect balance and symmetry. (89)

Clarissa's party planning is her attempt to control something in an otherwise chaotic world that has been devastated by the atrocities of war. Clarissa is concerned so much with the success of her party that she personally labors over her attire for the evening, mending her own dress so that her housemaids can continue preparing the home for her guests:

Her evening dresses hung in the cupboard. Clarissa, plunging her hand into the softness, gently detached the green dress and carried it to the window. She had torn it. Someone had trod on the skirt. She had felt it give at the Embassy at the top among the folds. . She would mend it. Her maids had too much to do. She would wear it tonight. She would take her silks, her scissors, her-what was it?her thimble, of course, down into the drawing room, for she must also write, and see that things generally were more or less in order. (MD 37)

Clarissa thinks of her clothes the same way she thought of her morning errand of buying flowers as she plunged her hand into her cupboard to retrieve her gown for the evening much like she plunged onto the streets earlier that day. Clarissa's attention to her attire and her appearance is an important part of being a good hostess. Beauvoir indicates that a woman's role is to objectify herself, present herself as an attractive ornament, much like 
the polished silver, or glittering crystal that a guest might admire. Beauvoir writes, "Woman. . . is even required by society to make herself an erotic object. The purpose of fashions to which she is enslaved is not to reveal her as an independent individual, but rather to cut her off from her transcendence in order to offer her as prey to male desires; thus society is not seeking to further her projects but to thwart them" (SS 529). Like the party itself, women assume control over the event and their appearances, but in reality, all things surrounding the social life have been prescribed by society itself; the hostess is merely doing what is required of her by the system. She is thus doing what she is told much like a child might when ordered to do something by a parent. Karen DeMeester argues that Clarissa's party is in many ways an escape from the horrors of the world, and while Clarissa does nothing to try and alter society, she does try to create a lovely place where people can forget the drudgeries for a while. DeMeester writes:

Clarissa accepts the choices she has made and the world she inhabits and, to a degree, that she herself has created. She does not try to change or influence the vicissitudes of fate and the high jinks of those ruffian gods, but rather looks for emotional and communal consolation, and through her parties, seeks to offer gifts of sympathy and comprehension to others. (90)

Clarissa's parties are her creative acts and she feels as if she is giving something to the people she gathers together at these events. Clarissa reflects upon the disparaging comments both her husband and Peter Walsh make about her parties and ultimately comes to her own realization about the purpose of her gatherings:

Her parties! That was it! Her parties Both of them criticized her very unfairly, laughed at her very unjustly, for her parties. That was it! That was it! Well, how was she going to defend herself? Now that she knew what it was, she felt perfectly happy. They thought, or Peter at any rate thought, that she enjoyed imposing herself; liked to have famous people about her; great names; was simply a snob in short. ... Richard merely thought it foolish of her to like excitement when she knew it was bad for her heart. It was childish, he thought. And both were quite wrong. What she liked was simply life.... 
But to go deeper, beneath what people said (and these judgements, how superficial, how fragmentary they are!) in her own mind now, what did it mean to her, this thing she called life? Oh, it was very queer. Here was So-and-so in South Kensington; some one up in Bayswater, and somebody else, say in Mayfair. And she felt quite continuously a sense of their existence; and she felt what a waste; and she felt what a pity; and she felt if only they could be brought together; so she did it. And it was an offering; to combine, to create; but to whom?

An offering for the sake of offering, perhaps. Anyhow, it was her gift. Nothing else has she the slightest importance; could not think, write, even play the piano. She muddled Armenians and Turks; loved success; hated discomfort; must be liked; talked oceans of nonsense: and to this day, ask her what the equator was, and she did not know. (MD 118-19)

In absence of anything else to offer society, Clarissa creates a place for people to come and create memories. It is through these memories that people, including her self, will live on. She realizes that both Peter and Richard think her parties frivolous and insignificant, but what else is Clarissa to offer society? She admits that her lack of talents and knowledge make any other offerings impossible and therefore, her parties are her gift to society. Clarissa has little control over anything else in her world, but she can create a space in which people can come in their finest dress and experience a beautiful place and time, even if only for a while. While Clarissa's parties are creative acts, ways for her to give her guests a memorable evening, she is nonetheless acting out a socially appropriate role for women of her class.

In preparation for her party, Clarissa tends to her evening attire, making sure that her appearance is appropriate for the party. Beauvoir explains that when a woman "care[s] for her beauty, to dress up, is a kind of work that enables her to take possession of her person as she takes possession of her home through housework; her ego then seems chosen and recreated by herself," and she seems to have some control in this social world (SS 529). However, Beauvoir's next statement indicates that this control is merely an illusion, and women who adorn themselves are merely doing so to keep in line with 
what society dictates: "Social custom further dictates this tendency to identify herself with her appearance" (SS 529). The patriarchs want a woman to distract herself with how she appears, to make herself up to please their eyes. She has no control here, for even the apparel she places upon her body is restricting her, much like the society itself. Beauvoir writes:

The skirt is less convenient than trousers, high-heeled shoes impede walking; the least practical of gowns and dress shoes, the most fragile of hates and stockings, are most elegant; the costume may disguise the body, deform it, or follow its curves; in any case it puts it on display. This is why dressing up is an enchanting game for the little girl, who loves to contemplate herself; later childish independence rises in rebellion against the constraint imposed by light-colored muslins and patent-leather shoes; at the awkward age the girl is torn between wish and the refusal to display herself; but when she has once accepted her vocation as sexual object, she enjoys adorning herself. (529)

Because these decorations are placed upon the body, a woman develops a personal relationship to these types of ornaments more so than the objects that decorate her house. She becomes, through decorating herself, the ultimate object. To deny this objectification is to deny societal roles. Mrs. Dalloway's daughter Elizabeth does not devote much attention to female decorations: "Gloves and shoes; she had a passion for gloves, but her own daughter, her Elizabeth, cared not a straw for either of them" (MD 9). The younger woman, perhaps a representation of the New Woman in society, was debunking societal convention and did not care about ornamental items used to make the female more appealing to men. As Beauvoir comments in The Second Sex, a woman in society must tend to her appearance or otherwise be cast out of social circles:

In refusing her role as object, she is defying society; she is perhaps an anarchist. If she simply wants to be inconspicuous, she must remain feminine. Custom regulates the compromise between exhibition and modesty; at one time it is the bosom that the "decent woman" must cover, at another time the ankles: sometimes the young girl may emphasize her charms to attract prospects, while the married woman gives up all adornment, as in many peasant cultures; at other 
times young girls are obliged to wear filmy, candy-colored frocks of conservative cut, while older woman are permitted clinging gowns, heavy materials, rich colors, and provocative styles. (529)

Elizabeth's disinterest in adornments is a clear sign of her non-conformity, a symbol of a young educated woman who is debunking conventional society. According to Beauvoir, a young woman like Elizabeth would suffer socially for her lack of interest in fashion and beauty.

Clarissa Dalloway, as she is portrayed not just in the novel Mrs. Dalloway, but also in the shorter fictional work, "Mrs. Dalloway in Bond Street," has fallen victim to her social position as it calls for great attention to female attractiveness. The first line of the short fiction describes Clarissa thinking of party details, but instead of flowers, "Mrs. Dalloway said she would buy the gloves herself" $(C S F 152)$. When Clarissa reaches the glove shop, great attention is paid to selecting just the right gloves for Clarissa's slender hands, and she considers purchasing stockings as well:

They sold stockings-silk stockings. A lady is known by her gloves and her shoes, old Uncle William used to say. And through the hanging silk stockings quivering silver she looked at the lady, sloping shoulder, her hand drooping, her bag slipping, her eyes vacantly on the floor. It would be intolerable if dowdy women came to her party! (CSF 152)

Clarissa's distaste for the unattractive women in the shop is a sign of her resignation to the importance society places upon the appearance of women, and how women themselves are complicit in these rules, even going so far as to impose beauty standards upon each other. Clarissa even claims that a dowdy woman could conceivably ruin the atmosphere of her party. While still at the glove shop, some glove material rips-“"And then the other customer took a glove, tugged it, and it split" --;the gloves do not seem to be of the same high quality: "'Gloves have never been quite so reliable since the war,' 
said the shop-girl, apologizing, to Clarissa" (CSF 158). The war, it seems, did more than just change the European landscape; it also changed the cultural landscape, for society was changing, and women's participation in society was shifting. The traditional ways of living were being tugged at and then ripped apart like the delicate party glove. Both of Woolf's Clarissas were model traditional women, and both were on the cusp of witnessing a great shift in their worlds, their societies, and their selves.

Clarissa, of the novel Mrs. Dalloway, tried to perform her role of hostess by the standards dictated by her society. Mrs. Dalloway was once a young girl in a fiery love affair with a man who wanted to consume her, and was once a girl who shared an intimate kiss with her girlhood friend:

Then came the most exquisite moment of her whole life passing a stone urn with flowers in it. Sally stopped; picked a flower; kissed her on the lips. The whole world might have turned upside down! The others disappeared; there she was alone with Sally And she felt that she had been given a present wrapped up and told just to keep it, not look at it - a diamond, something infinitely precious, wrapped up, which, as they walked (up and down, up and down), she uncovered, or the radiance burnt through, the revelation, the religious feeling! (MD 35)

Clarissa has grown into a woman defined by her husband's social standing: "She had the oddest sense of being herself invisible, unseen; . . . this being Mrs. Dalloway; not even Clarissa any more; this being Mrs. Richard Dalloway" (MD 10). Her marriage to Richard Dalloway has required Clarissa to become the ultimate hostess, opening her home to the governing class of which she (by proxy of her husband) is a member.

A model hostess, Clarissa prepares for a party that is to be attended by people of the governing class, which consists of people who have money, power, and position. While some members of this governing class are not necessarily lawmakers, they are however influential with their money and through their associations with those who do 
play political roles. This governing class, as a whole, maintains its power and its sanity by repressing any strong emotion, emotion represented by Woolf's characters like Peter Walsh, who has spent the past five years in the wilds of India, Sally Seton, who is a reminder of the carefree nature of the young, and of course Septimus Smith, the traumatized soldier who cannot regain his hold on reality. These characters are the antithesis of the stagnation and rigidity of the governing class whose interests are in maintaining the status quo, not altering a society from which they benefit greatly.

The upper-middle-class gathered at Clarissa Dalloway's party does not revel in emotion. Any emotion Clarissa, or anyone in the governing class may feel, must be suppressed, for the mentality of the upper-middle-class is, if emotion is expressed, the individual has lost control. Control is how the governing class maintains its privileges and is something that must never be lost. Therefore, Clarissa plays hostess to a house full of these people while emotional outsiders are kept away, i.e., the Septimus Smiths of the world, who cannot control their emotions. Clarissa herself is terrified by death and tries to distract herself from the inevitability of death by focusing on the details of hostessing. As Clarissa goes about her morning chore of buying flowers she wonders, "Did it matter then... did it matter that she must inevitably cease completely; all this must go on without her; did she resent it; or did it become consoling to believe that death ended absolutely?" ( $M D$ 9). Clarissa ponders life and death and organizes her parties in order to create memories for herself and for others, and ultimately hopes to achieve immortality as she lives on through other people as a figure they hold fondly in their memories. She does not like to think about war and its destruction, especially not at her party.

While Clarissa Dalloway's parties are in actuality a creative act, putting on 
parties in order to solidify memories for the attendees, she is none-the-less living up to the standards placed upon women by traditional society. Not only does she gather people together, but she also perpetuates society by introducing young women to prospective suitors, thus carrying on social life. In the shorter fictional work, "The Introduction," we see yet another version of Clarissa Dalloway, again at her party, and in attendance is a young woman, Lily Everit. Lily sits quietly in a corner, which will not suffice as good behavior at Clarissa's party: "As Mrs. Dalloway approached with her right hand raised and a smile which Lily knew (though this was her first party) meant: But you've got to come out of your corner and talk,' a smile at once benevolent and drastic, commanding.. . . (CSF 184). Whether or not guests are enjoying themselves and being social can have a large impact upon the success of a party. Clarissa bears down upon Lily from the other side of the room, for she cannot have a guest sulking about in the corner; Lily must mingle. Clarissa sees in this young woman a little of her younger self, the young girl she was before she became a society hostess, and wants to give Lily the benefit of her experiences by introducing her to a young man so that she may one day marry and play hostess at her own gatherings in the future. Thus the cycle of the traditional social life can continue:

Mrs. Dalloway felt, as she always felt remembering her youth, absurdly moved; youth meeting youth at her hands, and there flashing, as at the concussion of steel upon flint ... the loveliest and most ancient of all fires as she saw in Bob Brinsley's change of expression from carelessness to conformity, to formality, as he shook hands, which foreboded Clarissa thought, the tenderness, the goodness, the carefulness of women latent in all men, to her a sight to bring tears to the eyes, as it moved her even more intimately, to see in Lily herself the shy look, the startled look, surely the loveliest of all looks on a girl's face; and man feeling for this woman, and woman that for man,.. . humanity was sweet at its heart, thought Clarissa, and her own life (to introduce a couple made her think of meeting Richard for the first time!) infinitely blessed. And on she went. (CSF 87) 
When Lily meets Mr. Brinsley, Clarissa's own life is validated. As she sees the young

people react to each other according to society's rules, Clarissa can take a sigh of relief as traditions are carried on by the youth. Clarissa, as matchmaker/hostess is tending to her duties not just as a party maker, but also as a teacher of future party makers, making it her responsibility to ensure that society's rules are continued after her parties have ended. Completely unaware and uncaring about Lily's desires, Clarissa forces Lily into societal submission, pressuring her to conform to the standards of tradition and the rules of social life. Clarissa may not be aware of her role in the perpetuation of traditional society, a society in which both she and Lily are trapped. She may actually believe that she is doing Lily a good turn by teaching her how to maneuver herself through society. Nonetheless, Clarissa is fulfilling the duty of a society woman, carrying on the traditional values set forth by the patriarchal society.

\section{An Unexpected Guest: Death at the Party}

In the novel, Mrs. Dalloway, we see a shift in priorities. While Clarissa spends her entire day planning her gathering for that evening, her hostess veneer begins to weaken as her past and her present push through and begin to redefine what is important to Clarissa. In regard to the war, the young damaged soldier, Septimus Smith, is unable to leave the war in the past where it "belongs," and is deemed crazy because he cannot get a handle on the emotions he feels. He is unacceptable to people like Dr. Bradshaw, who later joins the party at the Dalloways' and discusses the suicide of the young man, reacting in an insensitive manner towards the situation by calling Septimus merely "a case": "Some case, Sir William was mentioning, lowering his voice. It had its bearing upon what he 
was saying about the deferred effects of shell shock ...Lady Bradshaw (poor goose —one didn't dislike her) murmured how, 'Just as we were starting, my husband was called up on the telephone, a very sad case"' $(M D 179)$. Clarissa is at first appalled that Dr. and Lady Bradshaw would bring death to her party. Clarissa thinks to herself, " Oh!...in the middle of my party, here's death... What business had the Bradshaws to talk of death at her party? A young man had killed himself. And they talked of it at her party-the Bradshaws, talked of death" (MD 179). Obviously, at first, Clarissa is thinking only of the success of her party, but, of course, she says nothing. Whatever emotion she feels about the situation, be it shock, anger, or sadness, she attempts to conceal it. To Clarissa, the party is supposed to be a time to create memories, and death must not imbue the memories she wishes to create. The topic of death is not appropriate party talk. However, Clarissa is deeply affected by the death of this young man, whom she has never met. She feels obliged to leave her party, the party she has so painstakingly planned, in order to sort out her "inappropriate" emotions. Clarissa is a prisoner in her own home, in her social class, and in her own mind. She must escape, hide, in order to cope with all of the thoughts and feelings welling up inside of her. And this surge of emotion is out of character for Clarissa. Woolf's character is trying to fit the mold of the traditional woman, but a glimmer of change is breaking through Clarissa's socially molded exterior as she realizes that the traditional mode of expression is suffocating. As Alex Zwerdling observes in Virginia Woolf and the Real World:

Clarissa's instant empathy with Septimus when his suicide is mentioned at her party is in marked contrast to the usual way she deals with outsiders. His death shatters her composure and touches her in a profoundly personal way. This is not at all the manner in which the rest of the governing class treats the threatening presences by which it is surrounded. (128) 
Why does Clarissa react in such an empathetic manner when she hears of the death of this young man? Clarissa proves that she is not a worldly woman; her political naiveté is evident as she confuses Armenians and Albanians: "no, she could feel nothing for the Albanians, or was it the Armenians? But she loved her roses (didn't that help the Armenians?)" (MD 117). Her confusion of world events is a clear indication of her submission to the traditional structure of society. She stays out of political matters, deeming that arena of life more appropriate for her husband. However, the party, which is a symbol of the traditional woman's work, is here, and Clarissa's perception changes as she becomes painfully aware of a new world left in the wake of the war. She can no longer ignore the changes; the death and destruction of the war that the upper echelon of society is trying to ignore has found its way into her revelry where its destruction continues as the joyous illusion of the party is disrupted by the figurative arrival of the dead soldier. Septimus Smith's uninvited presence at Clarissa's party destroys her traditional gathering and thus the traditional view of society, and Clarissa has a very nontraditional reaction to the news of the dead soldier. Clarissa, who before could not keep Armenians and Albanians clear, was now forced to understand what was happening in her world, and she realized that the minutia of her life that had pleased her very much before Death came to her social gathering could no longer serve as her life's fulfillment. As Smith ultimately kills himself, Clarissa Dalloway envies him his decision; she envies him his ability to escape what she now sees as the artificial social life, but finally she realizes that her life can be better. After taking a few moments to think to herself about the death of this young man, Clarissa realizes, "She felt glad that he had done it; thrown it away. The clock was striking. The leaden circles dissolved in the air. He made 
her feel the beauty; made her feel the fun. But she must go back. She must assemble. She must find Sally and Peter. And she came in from the little room" (MD 182). But is Clarissa returning to the party as the same traditional woman, or has she changed? Has the world changed? The clock strikes the hour of change for Clarissa as the old standards "dissolved in the air" and she emerged from that little room a changed woman. She searched for her emotional companions, Sally and Peter, those who did not fit the traditional definition of what society should be, like Septimus Smith.

Clarissa does return to her party, but now with her new outlook on their world, she is no longer the perfect hostess as outlined by Simone de Beauvoir. She has crossed over from the unfeeling, stoic governing class and felt emotions of the changing world. Septimus Smith is a Christ Figure for Clarissa, for through his death, Clarissa's view has changed. According to Christine Froula in "Mrs. Dalloway's Postwar Elegy: Women, War and the Art of Mourning," Septimus "suffers a death that enacts a potentially redemptive "message" of witness to social violence" (88). At one point in the novel, Septimus believes he is transforming into a tree as he becomes "rooted" to the pavement like a tree's roots digging deep into the ground:

But they beckoned: leaves were alive; trees were alive. And the leaves being connected by millions of fibers with his own body, there on the seat, fanned it up and down; when the branch stretched he, too, made that statement. The sparrows fluttering, rising, and falling in jagged fountains were part of the pattern; the white and blue, barred with black branches. Sounds made harmonies with premeditation; the space between them were as significant as the sounds. A child cried. Rightly far away a horn sounded. All taken together to mean the birth of a new religion. (MD 22)

Like the act of transubstantiation in which the bread and wine become the body and blood of Christ, Septimus is transforming in to a tree, not in appearance but rather in spirit. Becoming a Christ figure, Smith brings about the "birth of a new religion." The 
Christ figure image continues with the suicide of Smith. As he positions himself on the window sill, getting ready to jump so as not to be taken to the asylum, he thinks, "But he would wait till the very last moment. He did not want to die. Life was good. The Sun hot. Only human beings - what did they want?.. . 'I'll give it you!' he cried, and flung himself vigorously, violently down onto Mrs. Filmer's area railings." (MD 146). The final thoughts of Smith, "What did they want?" resonates with Christ's question on the cross, "Why have you forsaken me?" The utter confusion of both Smith and Christ about their persecution is notable, for they were only doing as they were told as Christ was governed by God and Smith governed by England. Both Christ and Smith were scapegoats for the sins of the populace. As her savior, Smith helps Clarissa to see life more clearly than she had before his death came to her party, and Clarissa realizes that life, and the people at her parties, are worth living for. In addition to liking life, Clarissa also comes to terms with her own mortality as she gazes at the old woman across the window:

She parted the curtains; she looked. Oh, but how surprising! - in the room opposite the old lady stared straight at her! She was going to bed. ... It was fascinating to watch her, moving about, that old lady, crossing the room, coming to the window. Could she see her? It was fascinating, with people still laughing and shouting in the drawing-room, to watch that old woman quite quietly, going to bed. She pulled the blind now. The clock began striking. The young man had killed himself; but she did not pity him. (MD 181)

According to Froula, “the unknown young man's death helps Clarissa to embrace life, beauty, fun, her party, all her consolations in face of time and inexorable loss-'that's what I do it for"" (118). Smith ends his life and Clarissa envies him his decision; she envies his ability to escape but finally realizes that her life is a good life enhanced by her parties. After taking a few moments to think to herself about the death of this young man, 
Clarissa realizes, "She felt glad that he had done it; thrown it away. . . he made her feel the beauty; made her feel the fun" ( $M D 182)$. Again, Smith is a Christ figure as his death is "used" for Clarissa's salvation.

Like the ripped glove from "Mrs. Dalloway in Bond Street," society, its definitions, and its traditions were ripping and coming apart as well. As Clarissa Dalloway shared in Septimus Smith's death, so too did the entire society share in the war, but unlike Clarissa, society was unwilling to acknowledge the trauma experienced by so many people, soldiers and non-combatants alike. Society was also unwilling to accept the changes occurring in the prescribed roles of both men and women. As illustrated in Mrs. Dalloway, society-at-large actually rejected reminders of the war, especially the soldiers who fought at the front and returned home as damaged males. As Karen DeMeester states:

Modernist forms reflect trauma on the most personal level, and meaning lies in the internal and private, the subjective, and the consciousness of the individual. But war is a particularly communal trauma and demands a collective response. For a soldier like Septimus Smith to find meaning in his combat experiences, his story must not only be heard but also understood by those in power. (91)

Those in power were unwilling to hear the soldier's story and forced him to either conform to societal standards or suffer the consequences. Septimus threw himself from a window as a result of society rejecting his experiences and his story, and as a woman who also experienced the war in her own way, Clarissa Dalloway understood and perhaps even envied Septimus' decision to escape the confines of traditional society. 


\section{The Young Girl: "She is awaiting Man"}

Woolf depicts many young women in her fictional works. Some of these young women conform to the expectations society has for a young woman, and then a few of them seem to be walking the line between acquiescing to society's rules, and becoming a New Woman. Simone de Beauvoir writes about the young woman as she is on the verge of becoming a woman in society. The young woman is being trained for her traditional role, but has not yet assumed her position completely, still playing at her femininity for she is not yet married and has not yet borne her children, which are presumably her main purposes in social life. What is most delightful is how Beauvoir uses Woolf's character Jinny from The Waves as a model in this section of The Second Sex to describe the young woman, as she begins her life in society. We can make many connections between the young woman Beauvoir describes in The Second Sex, and the young women Woolf writes, not just in The Waves, but also in her other fictional works such as To The Lighthouse with Lily Briscoe, and Mrs. Dalloway with the young Clarissa Dalloway.

Simone de Beauvoir discusses the young woman in two ways in this particular chapter. She focuses on a young woman in regards to her age, making the distinction between a child, and an older girl, and she discusses a young woman who is of marrying age but who has not yet found a husband. In regard to Woolf's works, I will focus more on developing the older, unmarried girls/women, for it is these women who seem to be making conscious decisions about their lives in society, choosing whether they will conform to traditional standards or not.

Beauvoir's young girl is waiting. She awaits growing older and assuming her role as dictated by patriarchal society. She is to become object of sexual desire, wife, lover, 
mother, homemaker, and caretaker. She is groomed for these roles from the very beginning. When she is just a child, she is already restricted in her activities, for some activities are appropriate or inappropriate for a young girl who will one day be a part of civilized society. But the girl-child may not realize that her future is already laid out before her. As Beauvoir writes, "Throughout her childhood the little girl suffered bullying and curtailment of activity; but none the less she felt herself to be an autonomous individual. In her relations with family and friends, in her schoolwork and her games, she seemed at the time a transcendent being: her future passivity was only a dream" (SS 329). The young woman can delude herself into believing that perhaps her adult life will develop with some freedoms, but if the young woman chooses to live within the confines of society, those freedoms are very difficult to come by. For when the young woman does decide to remove herself from her parents' home and care, she is doing so only because she has found a new home, with a new authority figure to dictate her activities, her husband. As Beauvoir claims:

There is unanimous agreement that getting a husband—or in some cases a "protector"-is for her the most important of undertakings. In her eyes man incarnates the Other, as she does for man; but this Other seems to her to be on the plane of the essential, and with reference to him sees herself as the inessential. She will free herself from the parental home, from her mother's hold, she will open up her future, not by active conquest but by delivering herself up, passive and docile, into the hands of a new master. (SS 329)

By moving from one dominated household to another, from parents to husband, a woman is never free to develop the self. If she is able to find and craft a talent, be it educational talents or something else, she will ultimately have to give that up if she wants to be accepted into society and accepted by a man. Beauvoir was writing during the post war period as the French government was actively promoting traditional roles of women, 
including marriage and motherhood. According to her cultural situation, Beauvoir believed that since a woman is unable to develop her own professional life and to secure her own financial future, she must rely upon the possibility of marriage to ensure a comfortable future. If she chooses to accept her social lot, she is giving in to society rather than revealing a truth about a woman's inability to take care of herself in society. Beauvoir makes this distinction:

It has often been asserted that if she resigns herself to such submission, it means that she is inferior to boys materially and morally and is incapable of rivalry with them: abandoning a hopeless contest, she leaves to a member of the superior caste the task of assuring her happiness. But the fact is that her resignation has its source in the adolescent girl's past, in society around her, and particularly in the future assigned to her. (SS 329)

Her resignation to join society rather than live on its perimeters says more about her character than her abilities. If a woman does not have the desire to develop her own project, if she wishes to be a part of society rather than a social pariah, then her future is settled, and she will become a wife and mother, chained to the private sphere where traditionally the patriarch of the family will rule her.

Woolf depicts young, unmarried women in her fictional works, but Beauvoir refers to one in particular, from The Waves, as she focuses on the character Jinny. Beauvoir argues that as the young girl concedes to the society, she obviously must be attentive to her appearance as mentioned in the discussion of the social life. The young woman must, in order to attract a potential husband, tend to her appearance. Beauvoir writes:

The young girl has in the end accepted her femininity - unless she is especially ill-favored; and frequently she is happy to enjoy without cost the pleasures and triumphs it provides, before becoming definitely settled down in life; not as yet bound to any duties, irresponsible, at liberty, she none the less views the present 
as neither empty nor delusive, since it is only a stage; dressing up and flirting still seem but a game, and her dreams of the future hide its futility. (SS 366)

Beauvoir continues claiming that Woolf's Jinny exhibits these characteristics as she flirts and takes pride in her youth and her appearance, becoming increasingly excited at how desirable she seems to be. As Beauvoir shows, the tactile description of Jinny's thoughts forces us to focus on the concrete body and its attributes rather than on any mental abilities a young woman may have:

I feel myself shining in the dark. Silk is on my knee. My silk legs rub together. The stones of a necklace lie cold on my throat. ... I am arrayed, I am prepared. . . . My hair is swept in one curve. My lips are precisely red. I am ready now to join men and women on the stairs, my peers. I pass them, exposed to their gaze, as they are to mine.... I now begin to unfurl, in this scent, in this radiance, as a fern when its curled leaves unfurl. (Waves 101-2)

Jinny's awareness and attention to her appearance, her adornments as she places herself on display (enjoying being looked upon) is an indication of her acquiescence to her role in society as a sexual object. She wishes to join her peers, seeing this moment as a rite of passage in which she is moving from one phase of her life into another, leaving her young girlhood behind and joining adult society. Jinny continues thinking about her transitioning moment:

I feel a thousand capacities spring up in me. I am arch, gay, languid, melancholy by turns. I am rooted, but I flow. All gold, flowing that way, I say to this one, "Come...." He approaches. He makes towards me. This is the most exciting moment I have ever known. I flutter, I ripple. ... Are we not lovely sitting together here, I in my satin; he in his black and white? My peers look at me now. I look straight back at you men and women. I am one of you. (Waves 102-3)

Jinny is on display, and the pride she is taking in being looked upon and admired is great. She has accepted her place in society as she becomes "one of them," a member of that world in which her role has already been defined, and a role which she has accepted as she places herself into submission as she waits for the man to "approach" her, and "he 
makes towards" her while she waits in great anticipation for what is to happen next. As Beauvoir explains, "For the young girl, erotic transcendence consists in becoming prey in order to gain her ends. She becomes object, and she sees herself as object" (SS 337). Jinny objectifies herself as she seems to be "awaiting Man" (SS 328). She is blinded by the flowing gold and finery and sees nothing but the acceptance of her peers. Beauvoir explains the transition of a young girl into a young woman as the young woman begins to desire exactly that which society wants her to desire:

As the girl matures, her mother's authority weighs more heavily upon her. If she does housework at home, she hates to be only an assistant, for she would like to devote her effort to her own home and her own children. Frequently she finds rivalry with her mother disagreeable, and she is especially disturbed if younger brothers or sisters are born; she feels that her mother has had her day and it is now time for her to have children, to take charge. (SS 367)

The young woman can begin to resent her own mother for the role that the mother holds in the household. The young woman, seduced by the finery of society and reverence towards the wife and the mother, now desires to become that type of woman herself. And this is how society perpetuates itself. She becomes less interested in love and romance and more concerned with a proper marriage, a marriage that will allow her to assume the role she was born into society to fulfill.

Woolf's Clarissa Dalloway, as a young woman, toyed with the possibility of a non-traditional life, but in the end, decided that marrying an appropriate man, appropriate by traditional society's standards, was best for her future. Her relationship with Peter Walsh when she was a young woman is in stark contrast to that with Richard Dalloway, for one man's fiery desire for her seemed all-consuming, whereas her future husband seemed to want a cooler relationship with his wife. There is another relationship, 
however, that depicts the young, unmarried Clarissa as a bit more rebellious than what is accepted by society. This relationship is with her girlhood friend, Sally Seton.

The novel Mrs. Dalloway plunges right into a memory of young Clarissa at Bourton "in the open air" which is quite a contrast to the city in which the older Clarissa lives. Young Clarissa's experience of the world on that morning is fresh and vibrant as her age is fresh and vibrant: "How fresh, how calm, stiller than this of course, the air was in the early morning; like the flap of a wave, the kiss of a wave; chill and sharp and yet (for a girl of eighteen as she then was) solemn, feeling as she did, standing there at the open window, that something awful was about to happen" $(M D 4)$. What was about to happen that was to be so awful? It is as if the young Clarissa can sense the impending future, already laid out in front of her, or perhaps she could sense a shift in society as the First World War would be an important and influential component in her life. Either way, Clarissa's sense that "something awful was about to happen" can refer to what is in store for her as she becomes a part of traditional society.

Before she married Richard Dalloway, the more appropriate choice for her husband by traditional standards in regards to Richard's class, position, and power in society, Clarissa had a relationship with Peter Walsh. Whereas Richard represents composure and temperament, Peter represents emotion. Clarissa believes that had she married Peter when she was younger, it would have been a mistake: "It would not have been a success their marriage," for Peter's passions and emotions were too strong for her and she feared he would ultimately consume her (MD 152). As Clarissa matured, in regards to her class and society's standards, her priorities changed and she wanted something else that she felt Peter could not offer her: 
[Richard] would tell Clarissa that he loved her, in so many words. He had, once upon a time, been jealous of Peter Walsh; jealous of him and Clarissa. But she had often said to him that she had been right not to marry Peter Walsh; which knowing Clarissa, was obviously true; she wanted support. Not that she was weak; but she wanted support. ( $M D 114)$

Clarissa decided that she needed to be taken care of, and Richard could provide that stability. Richard's propriety and his ability to control his emotions (he would tell her he loved her ... in so many words) distinguishes him from Peter Walsh, who was driven by his passions and romantic love. Clarissa too began to control her emotions rather than allow her childish whims to take over. At the beginning of the novel, we see a youthful Clarissa plunging into the natural world, whereas after she meets Mr. Richard Dalloway, she had changed:

Sally at lunch saying something about Dalloway, and calling him "My name is Dalloway"; whereupon Clarissa suddenly stiffened, coloured, in a way she had, and rapped out sharply, "We've had enough of that feeble joke." That was all; but for [Peter] it was precisely as if she had said, "I'm only amusing myself with you; I've an understanding with Richard Dalloway." (MD 62)

The young Clarissa from earlier in the novel has become a stiff society woman as her interests shift from the emotional Peter to the more suitable Richard Dalloway. Her reaction to Sally's jesting is a clear indication of not only her interest in Richard, but also her interest in social propriety, as she seemed to chastise Sally for being a little inappropriate. Clarissa had made her choice, and when she finally decided that it was Richard Dalloway that she wanted and not Peter, she ended their relationship. Peter could not but express his despair during that difficult moment:

"Tell me the truth," he repeated. He felt that he was grinding against something physically hard; she was unyielding. She was like iron, like flint, rigid up the backbone. And when she said, "It's no use. It's no use. This is the end"-after he had spoken for hours, it seemed, with tears running down his cheeks - it was as if she had hit him in the face. She turned, she left him, went away. "Clarissa!" he 
cried. "Clarissa!" But she never came back. It was over. He went away that night. He never saw her again. (MD 63)

Peter's inability to control his emotional response to losing Clarissa makes him the antiRichard. The governing class maintained its position through control, and that included controlling emotions. Even when it came to romantic gestures, Richard Dalloway still seemed to go through the motions with rigidity and propriety: "Bearing his flowers like a weapon, Richard Dalloway approached her" (MD 113). Richard, being more formal, became for the young Clarissa the man she needed to help her through society. Everyone who knew Peter understood him to be a man driven and consumed by his passions, and that was not the sort that was going to help the young Clarissa develop her traditional role as wife, mother, and social being: "Peter always in love, always love with the wrong woman? What's your love? She might say to him. And she knew his answer; how it is the most important thing in the world and no woman possibly understood it" (MD 119). Peter is in sharp contrast to Richard and even to Clarissa herself as she transitioned from a young girl to an unemotional society woman who cared more for the companionate relationship she had with Richard than she did for the romantic relationship she had with him: “. . Clarissa so calm, so cold, so intent on her dress or whatever it was; realizing what she might have spared him, what she had reduced him to-a whimpering, sniveling old ass. But women, he thought, shutting his pocketknife, don't know what passion is. They don't know the meaning of it to men. Clarissa was as cold as an icicle" (MD 78). The young Clarissa is also contrasted with the young Sally Seton. Clarissa envied Sally her ways, but Clarissa could never quite bring herself to act in the same ways or with the same gusto as Sally. One of the most important moments in young Clarissa's life 
(or older Clarissa for that matter) was when she and Sally shared a kiss, but Peter

interrupted the moment, as he continued his passionate quest to consume all of Clarissa:

Then came the most exquisite moment of her whole life passing a stone urn with flowers in it. Sally stopped; picked a flower; kissed her on the lips. The whole world might have turned upside down! The others disappeared; there she was alone with Sally And she felt that she had been given a present wrapped up and told just to keep it, not look at it - a diamond, something infinitely precious, wrapped up, which, as they walked (up and down, up and down), she uncovered, or the radiance burnt through, the revelation, the religious feeling! — when old Joseph and Peter faced them: "Star-gazing?" said Peter. It is like running one's face against a granite wall in the darkness! It was shocking; it was horrible! ( $M D$ 35)

Clarissa resented Peter for interrupting that blissful moment between her and Sally. She admired Sally's ability to live against the grain, to debunk societal conventions, and try doing things in her own unique way. Even the way Sally arranged flowers impressed Clarissa:

Sally's power was amazing, her gift, her personality. There was her way with flowers, for instance. At Bourton they always had stiff little vases all the way down the table. Sally went out, picked hollyhocks, dahlias-all sorts of flowers that had never been seen together-cut their heads off, and made them swim on the top of water in bowls. The effect was extraordinary - coming in to dinner in the sunset. (Of course Aunt Helena thought it wicked to treat flowers like that.) $(M D 33)$

Sally was defiant and refused to conform, making her an example of the New Woman in modern society. Lured by Sally's enigmatic presence, Clarissa allowed herself to fall prey to nonconformity even if just for a moment, but was then pulled away by her conventional duties, namely attention to male companions. Clarissa secretly longed for that feeling she had with Sally that she believed she could only have with a woman:

The strange thing, on looking back, was the purity, the integrity, of her feeling for Sally. It was not like one's feeling for a man. It was completely disinterested, and besides, it had a quality which could only exist between women, between women just grown up. It was protective, on her side; sprang from a sense of being in 
league together, a presentiment of something that was bound to part them (they spoke of marriage always as a catastrophe).... (MD 33)

Despite their young sentiments about marriage, Clarissa's interest in a traditional life kept her from further exploring a taboo relationship with Sally, and instead beginning a relationship with a very traditional man. Sally's actions as a young woman were more in line with that of the New Woman as she was emerging in Woolf's society. Sally was a little freer and went against the current with her reckless behavior of smoking and bicycling "round the parapet on the terrace" (MD 33). As far as Simone de Beauvoir's discussion of the young girl in The Second Sex, the young Clarissa Dalloway has the makings of a woman who might not follow the footsteps which have been laid before her, but she then reverts to type, marrying the safer choice, Richard Dalloway, and entering a life that would present few surprises and a great deal of support and control.

The young woman presented in Woolf's shorter fiction, "The Introduction" presents an interesting image when read through the lens of The Second Sex, for Lily Everit does not seem to respond to the men at the Dalloway party the way that a young woman in society should. Instead of offering herself up as a sexual object to be admired and desired, as Beauvoir accuses young women of doing, Lily prefers to remain in the corner, playing the part of the observer rather than the observed. Of course this behavior is unacceptable to the hostess, and Lily is forced from her voyeur's corner and placed in front of a man, Mr. Brinsley, so that he may objectify her, reducing her to just a woman rather than the intellectual being she actually is:

In spite of all she could do her essay upon the character of Swift became more and more obtrusive and the three stars burnt quite bright again, only no longer clear and brilliant, but troubled and bloodstained as if this man, this great Mr. Brinsley, had just by pulling the wings off a fly as he talked (about his essay, about himself 
and once laughing, about a girl there) charged her light being with cloud, confused her forever and ever and shriveled her wings on her back. (CSF 188)

The butterfly metaphor is important in this passage, for the metamorphosis a butterfly must go through in order to have wings mimics the changes women were going through in society during the time of the First World War. While trapped in a cocoon, a butterfly must develop the wings necessary to fly. Lily is that butterfly, trapped within the cocoon of society while developing her wings. A symbol of the New Woman, Lily has the ability and intellect to fly on her own, but in order to keep her from escaping, society must cut off her wings. Lily feels amputated by this man of society, but she cannot seem to succumb to her duties as a young lady at a social gathering whose responsibility is to reflect back onto the young man all he wishes to see in himself; she is to act as a looking glass so that he may admire himself. And while on the outside she may seem the perfection of a proper young lady, her inner thoughts reveal a woman who is miserable within the confines of the party. But under the watchful eye of the hostess, Lily must reflect the image of propriety, allowing the young man to fly, while she remains wingless.

According to Simone de Beauvoir, if a young woman does not devote herself entirely to her feminine obligations and instead focuses her efforts on personal endeavors, then she may fear that her social standing will suffer as a result. As Beauvoir explains:

She is likely to fear that if she devotes herself completely to some undertaking, she will miss her womanly destiny. ... It weakens well-defined purposes, it sets limits. In any case, the woman who works wishes to reconcile her professional success with purely feminine accomplishments. .. It is not a matter of mental weakness, of an inability to concentrate, but rather of division between interests difficult to reconcile. A vicious cycle is established and it is often astounding to see how readily a woman can give up music, study, her profession, once she has found a husband. (SS 369) 
In Beauvoir's opinion and based on her cultural situation as a modern woman in early $20^{\text {th }}$ century France, there is a choice, and if a woman is able to choose herself and her own individual accomplishments, then she is not welcomed into that society. This is reminiscent of Woolf's Lily Briscoe in To The Lighthouse. Throughout the novel, we know that Lily is trying to finish her painting, but there always seems to be a distraction or a reason that she cannot complete her art. Finally, at the end of the novel, after many years have passed, Lily finally finishes her painting:

It would be hung in the attics, she thought; it would be destroyed. But what did that matter? She asked herself, taking up her brush again. She looked at the steps; they were empty; she looked at her canvas; it was blurred. With a sudden intensity, as if she saw it clear for a second, she drew a line there, in the centre. It was done; it was finished. Yes, she thought, laying down her brush in extreme fatigue, I have had my vision. (TTL 208-9)

Lily finished her art because she could now focus on the development of her own self without the distractions of society embodied in Mrs. Ramsay. If Lily had been more focused on being a proper young woman who was interested in marriage and children, would her own painting ever have gotten finished? If we use the thought of Beauvoir to examine Lily, she might have relinquished her own ambitions to please others, namely men, but since Lily never fell into that particular societal trap, she was able to express her own vision.

Perhaps not as young and attractive a single woman as the other examples Woolf provides, Miss Kilman in Woolf's Mrs. Dalloway illustrates a different kind of woman who has rejected marriage and thus rejected conforming to current social standards. In many ways, Miss Kilman represents the New Woman, intelligent and employed, making her own way as she tries to tutor the young Elizabeth Dalloway about a world that is opening for her in ways that Kilman was unable to experience. However, while Kilman 
can be described as the New Woman in positive terms, Woolf depicts poor Doris Kilman as an outcast, rejected by society, hated by Clarissa Dalloway, and somewhat pitied by her young and beautiful student, Elizabeth Dalloway. All of these negative thoughts about Doris Kilman are a direct result of her unwillingness to conform to societal standards and to live life as a spinster.

Miss Kilman feels cheated by the injustices in English society that had stripped her of a good teaching position. Contrary to her own best interests, Miss Kilman would freely express her sympathetic attitude towards Germans during war time when those were not the popular sentiments to hold:

She had been cheated. Yes, the word was no exaggeration, for surely a girl has a right to some kind of happiness? And she had never been happy, what with being so clumsy and so poor. And then, just as she might have had a chance at Miss Dolby's school, the war came; and she had never been able to tell lies. Miss Dolby thought she would be happier who shared her views about the Germans. She had had to go. It was true that her family was of German origin; spelt the name Kiehlman in the eighteenth century; but her brother had been killed. They turned her out because she would not pretend that the Germans were all villainswhen she had German friends, when the only happy days of her life had been spent in Germany! (MD 120-1)

Miss Kilman's unwillingness to conform to the popular way of thinking makes her markedly different from most of the women of her time, especially Clarissa Dalloway who prides herself on being socially acceptable. Miss Kilman is an educated and clever woman who would no doubt understand the difference between the Armenians and the Albanians, unlike Clarissa who focuses most of her thoughts on her social gathering, a gathering to which Miss Kilman is not invited. Because she does not fit Clarissa's social standard, Miss Kilman will remain absent from her party, or any party for that matter, but Miss Kilman does not want to be associated with people like Clarissa Dalloway, for she pities women like that: 
I never go to parties," said Miss Kilman, just to keep Elizabeth from going. "People don't ask me to parties"... . She had suffered so horribly." Why should they ask me?" she said. "I'm plain, I'm unhappy.". . .

"I don't pity myself," she said. "I pity"- -she meant to say "your mother" but no, she could not, not to Elizabeth. I pity other people," she said, "more." (MD 129)

So while Miss Kilman resents the social life she is obviously left out of and the people who exclude her, she does not wish to become the woman she must in order to be acceptable in society. She is not interested in the things a single woman should be interested in - her appearance, her clothes, the way she is seen by men. She rejects these things thus positioning herself outside of society. While Elizabeth Dalloway too is not interested in attending her mother's party, she still does, and she is able to perform her womanly duties of becoming an object of desire as she pays attention to her appearance for her mother and their guests. Miss Kilman does not have the skills to turn on and off her nonconformity and therefore she remains awkward around others. According to Johanna Garvey in "Difference and Continuity: The voices of Mrs. Dalloway," "Miss Kilman in her water-repellent mackintosh has rejected almost all forms of social communion, heterosexual ones in particular. At odds with the world in general, hostile and alienated, she leads a life of abnegation, of constant self-denial and self torment" (70). Like her coat, Miss Kilman repels society by refusing to conform to womanly standards. Even shopping for garments, a chore that has a strong female connotation, sends Miss Kilman spinning into what can be described as a phobic reaction, illustrating her discomfort with anything that could be defined as "socially appropriate":

So she sat. She got up, blundered off among the little tables slightly rocking from side to side, and somebody came after her with her petticoat, and she lost her way and was hemmed in by trunks especially prepared for taking to India; next got among the accouchement sets, and baby linen; through all the commodities of the world, perishable and permanent, hams, drugs, flowers, stationary, variously 
smelling, now sweet, now sour she lurched; saw herself thus lurching with her hat askew, very red in the face, full length in a looking-glass; and at last came out into the street. (MD 130)

In a single moment as she tripped through a shop, trying to escape, Miss Kilman is bombarded with everything that is feminine and social. As she tries to leave, she is followed as "somebody came after her" trying to return her forgotten petticoat, using it like a weapon. Childless, Miss Kilman is trapped by baby linens. With few acquaintances with which to correspond, Miss Kilman is faced with stationary, and unlike Clarissa Dalloway, she tries to get away from the flowers. In fact, Kilman's shopping outing is in definite contrast to Clarissa's, for Clarissa was calm and enjoyed being out, gathering items for her party. Kilman's response to her shopping outing was flustered and panicked. Finally, as Miss Kilman has almost escaped the store, she is faced with the mirror, reflecting the image of a woman who is not fit for society. As Miss Kilman finds herself surrounded by the "commodities of the world" and of society, she rejects them, and instead prefers her own intellectual devices on the public streets of London over the physical glitter and finery of the private houses of people like the Dalloways. Rejecting the confinement of society, Doris Kilman remains unmarried, childless, and uninterested in all things feminine like clothing and appearance. She is the New Woman, educated, self sufficient, and unattached, and while society judges her harshly and defines her not by the man she has but by the man she hasn't, Kilman remains a symbol of the possibility of female independence and of the injustices present in society. 


\section{The Wife and Mother: You Can't Have One Without the Other!}

Simone de Beauvoir dedicates a great deal of The Second Sex to the discussion of the wife and the mother, both representing societal institutions that have oppressed women for centuries. Beauvoir's ideas about motherhood are far from positive as she claims that women are subject to enforced maternity as she saw it in post-war France, as women had access to very little birth control. Beauvoir delivers an extensive discussion about abortion, calling it a desperate remedy to unwanted pregnancies, but states that women had very few options to maintain any control over their bodies. She writes, "enforced maternity brings into the world wretched infants, whom their parents will be unable to support and who will become the victims of public care or "child martyrs"" (SS 485). Beauvoir goes on to explain that while there are women who wish to be mothers and who enjoy the thought of motherhood, there are many other woman who have no choice but to succumb to motherhood against their will and possess few options to control pregnancy before or after conception (SS 485). According to Linda M.G. Zerilli in

"A Process without a Subject: Simone de Beauvoir and Julia Kristeva on Maternity,":

If this now familiar statement proved scandalous in postwar France, it was not only because Beauvoir dared to redefine the crime of abortion as a woman's right to terminate a pregnancy, it was also because that redefinition constituted a feminist intervention that neither elided nor simplified but addressed and complicated the very question of femininity by making visible, by voicing, the complexity of female desire. (117)

If a woman wanted to end a pregnancy, a natural biological function deemed by society to be the epitome of a woman's role in the world, then who was she? If a woman is not a mother, then what is her purpose in the world? Beauvoir questioned the necessity for women to fulfill their maternal role in society thus disrupting the basis of the definition of women in the world. Beauvoir goes on to explain the contradictory nature between that of 
patriarchal state refusing women who have no desire to have a child access to birth control, and the patriarchal state abandoning an unwanted child after it is born to parents who never wanted it in the first place. She writes, "It must be pointed out that our society, so concerned to defend the rights of the embryo, shows no interest in the children once they are born; it prosecutes the abortionists instead of undertaking to reform that scandalous institution known as 'public assistance"' (SS 485). Beauvoir offers examples of the hypocrisy of the state's control of, and interest in, the reproductive rights of women, but its lack of control of, and interest in, the needy children of the state:

Within a single week we have lately seen a surgeon commit suicide because her was convicted of practicing abortion, and a father who had beaten his son almost to death given three months in prison, with sentence suspended. Recently a father let his son die of croup, for lack of care; a mother refused to call a doctor for her daughter, because of her complete submission to God's will. (SS 485)

Beauvoir goes on to explain that when people complained about these cases, the general answer was that these children belonged to the parents and outside interference was unacceptable. Beauvoir's argument is that the children only belong to the parents when the state agrees; the child does not belong to the parents if the parents are deciding to terminate the pregnancy. Beauvoir is arguing against the state's intrusion into the private life and autonomy of a woman, deciding for her how she will or will not live her life.

Beauvoir also argues against a woman's second-class status in marriage as well as in procreation. Even though marriage is supposed to be a contract between both a man and a woman, it is the woman who falls into submission as the man takes his position as head of the family. As Beauvoir argues in 1949 as she writes The Second Sex:

Marriage has been a very different thing for man and for woman. The two sexes are necessary to each other, but this necessity has never brought about a condition of reciprocity between them;... . A man is socially an independent and complete individual; he is regarded first of all as producer whose existence is justified by 
the work he does for the group; we have seen why it is that the reproductive and domestic role to which woman is confined has not guaranteed her an equal dignity. (426)

Within the marriage, a wife's contribution to the relationship is not financial; she does not make any money for her labor. Therefore, her role is considered secondary to the husband's role, for he goes into the public sphere and earns a living for his family. The unfortunate aspect of this arrangement is that while she is placed in a submissive role because he does not work outside of the home, a wife cannot raise her position by attaining employment because social propriety does not allow such activities for women. Her role is, according to Beauvoir, very simple to define, for it is repetitious in nature:

But she has no other job than to maintain and provide for life in pure and unvarying generality; she perpetuates the species without change, she ensures the even rhythm of the days and the continuity of the home, seeing to it that the doors are locked. But she is allowed no direct influence upon the future nor upon the world; she reaches out beyond herself toward the social group only through her husband as intermediary. (SS 430)

The housewife in France at the mid-century was unable to contribute to the financial stability of the home and therefore held no power other than what was given to her by the provider/husband.

Woolf also discusses the idea of female financial independence in $A$ Room of One's Own when she asks, "Why did men drink wine and women water? Why was one sex so prosperous and the other so poor? What effect has poverty on fiction? What conditions are necessary for the creation of works of art?" (25). Woolf ponders women's abilities to create something of their own and states, "A woman must have money and a room of her own is she is to write fiction. ..." (4). Woolf considers economic independence essential for a woman's ability to create, but within the confines of the 
private sphere, women have always been kept from achieving this aim. Woolf continues, connecting the chance of financial independence to intellectual freedom. She writes:

Intellectual freedom depends upon material things. Poetry depends upon intellectual freedom. And women have always been poor, not for two hundred years merely, but from the beginning of time. Women have had less intellectual freedom than the sons of Athenian slaves. Women, then, have not a dog's chance of writing poetry. That is why I have laid so much stress on money and a room of one's own. (AROO 108)

According to Woolf, women historically have been poor, and because of their lack of financial strength, they have been relegated to the private sphere where daily chores are women's primary work. Her housework and the labor of tending to the children, while necessary activities, are not considered worthy of financial compensation nor do they afford her a say in household decisions unless her husband grants her decision-making privileges. If he does in fact give her some power within, or even outside, of the home, the fact remains that the power was given rather than taken, and this can create an illusion of equality: "Many young households give the impression of being on a basis of perfect equality. But as long as the man retains economic responsibility for the couple, this is only an illusion" ( $S S 480$ ). The problem, according to Beauvoir, is that a married couple is ideally regarded as one, but the married individuals are not treated as equals. She writes:

The couple should not be regarded as a unit, a closed cell. Rather each individual should be integrated as such in society at large, where each (whether male or female) could flourish without aid; then attachments could be formed in pure generosity with another individual equally adapted to the group, attachments that would be founded upon the acknowledgement that both are free. (SS 479)

The problem is, however, that within the confines of society, a couple are married not because they value each other's individuality, but rather because each offers the other some sort of socially appropriate commodity; the husband provides a home and a lifestyle 
that allows for social gatherings and comfort, and the wife provides her reproductive services and hostess abilities. Beauvoir goes on to argue that it is foolish to expect a man and woman who barely know each other and who are probably marrying, not out of love and passion, but out of social necessity (perhaps even through familial arrangement) to fulfill all needs, emotional, and physical, that the other may have. This sets up the institution of marriage for failure, or at the very least, disappointment. This distorted view of marriage, once realized can lead to "hypocrisy, lying, hostility, and unhappiness" (SS 479).

Beauvoir also makes a distinction between lower class women and middle or upper class women, for lower class women might need to work outside of the home for mere survival, but they still may not have much power in their marriage. Middle and upper class women are able to employ domestic workers, and while this luxury affords them the freedom from having to tend to housework, it actually cuts into some of the activities they are allowed to do to take up their time. Beauvoir claims that "Middle class women who employ help. . . are almost idle; and they pay for their leisure with ennui. If they lack outside interests, they often multiply and complicate their domestic duties to excess, just to have something to do" (SS 454). This idea is reminiscent of Clarissa Dalloway as she decides to buy the flowers for her party herself, or when she insists on mending her own party dress even after her maid offers to fix it for her. Clarissa felt that she needed to have a few chores to help prepare for her party. She needed to be useful.

Within the novel, Mrs. Dalloway, the title character is of course always the wife and mother focused upon. However, there is another wife within the story whose position not only in her marriage, but also in proper English society, is certainly second-class. 
Lucrezia Smith is in the most oppressive situation, for her husband has returned from the war as a damaged male. She is not only a slave to her husband/master, but also to the dominating patriarchy at large which is presents in the forms of the government that sent her husband off to war only to return home shell-shocked and incapable of performing any of his husbandly duties, as well as her husband's doctors who instruct her on how best to handle her relationship with Septimus and his mental illness. She is powerless, even as she instructs her husband on how to cross a street:

"Come on," said Lucrezia.

But her husband, for they had been married four, five years now, jumped, started, and said, "All right!" angrily, as if she had interrupted him.

People must notice; people must see. . . . Septimus had said, "I will kill myself"; an awful thing to say. Suppose they had heard him? She looked at the crowd. Help, Help! She wanted to cry out to butchers' boys and women Help! . . .She must take him way into some park.

"Now we will cross," she said.

She had a right to his arm, though it was without feeling. He would give her, who was so simple, so impulsive, only twenty-four, without friends in England, who had left Italy for his sake, a piece of bone. (MD 15-16)

While Lucrezia is directing Septimus on their walk, even though she is deciding when they will cross the street, he is still the one with the control in their marriage. As Beauvoir states, many younger couples are able to give the illusion of equality. While Lucrezia and Septimus might seem equal to an onlooker or a passer-by, he is in fact in control of her and their marriage. In some respect, Septimus is in control of himself; he controls whether he lives or dies, and Lucrezia knows that if he refused to cross the street, there would be nothing she could do about it. Lucrezia does love Septimus, but she has no real way of reaching him in his post-war madness. In one moment, she is frustrated and wishes he would be a man of his word and kill himself and then the next moment, she acknowledges that she could not live without him: "Nothing could make her happy 
without him. Nothing! He was selfish, So men are. For he was not ill. Dr. Holmes said there was nothing the matter with him. She spread her hand before her. Look! Her wedding ring slipped-she had grown so thin. It was she who suffered - but she had nobody to tell" (MD 22). Lucrezia's isolation in her marriage is depressing. A stranger in an unknown country with no one to help her, Lucrezia is alone, not to mention, childless. In his darkness, Septimus has not impregnated Lucrezia. He has given up sex:

Love between a man and a woman was repulsive to Shakespeare. The business of copulation was filth to him before the end. But, Rezia said, she must have children. They had been married five years. ... One cannot bring children into a world like this. One cannot perpetuate suffering, or increase the breed of these lustful animals, who have no lasting emotions, but only whims and vanities, eddying them now this way, now that. (MD 87)

Lucrezia's inability to fulfill her desire, even a desire that arises from social conventions, is not necessarily her inability, but her husband's unwillingness to let her have it. Once Septimus kills himself by throwing his body out of a window, he yells "I'll give it you!" Thought to have many meanings, perhaps this statement can be interpreted to mean that he will give Lucrezia a chance at a life more in line with what she wants or needs. By killing himself, he releases her from his own shackles. However, he has to give it to her, for she cannot take it herself. Lucrezia is a strong example of a woman in a young marriage who must submit to the needs and desires of her husband, even when his desires are to remain childless, to no longer be married, and to die. Simone de Beauvoir writes an interesting passage in her chapter "The Married Woman" that discusses how men can perhaps feel oppressed in society, much like Septimus felt, for he was a victim of his own patriarchal society:

If it is asserted that men oppress women, the husband is indignant; he feels that he is the one who is oppressed-and he is; but the fact is that it is the masculine code, it is the society developed by the males and in their interest, that has 
established woman's situation in a form that is at present a source of torment for both sexes. (SS 481-2)

Septimus is oppressed by his own patriarchal society, as the male-dominated government ships young men off to war to protect their own interests, and who, when the damaged males return from war, push them to the margins of society to be ignored.

Lucrezia, when her traumatized husband returns from the patriarchal war, is left alone to deal with what the government has created in her husband. She has no help, no resources, no power whatever to change her situation. In many ways, they are both oppressed, but Lucrezia's complete lack of resources leaves her vulnerable in a dangerous world. Beauvoir writes, "Woman leans heavily upon man because she is not allowed to rely on herself," but what happens when a husband is unable to handle the pressure of society? (SS 482). In the case of Septimus Smith, he jumped and left his wife alone.

Within the same novel, while Lucrezia never has a child, Clarissa does have a young daughter, and their relationship contains a little strain and disconnect as Clarissa feels her daughter slipping away from her and aligning herself more with the dreaded Miss Kilman. Clarissa develops anxiety as her daughter pulls away to form her own individuality, and that individuality is very different from her mother's, for Elizabeth Dalloway "cares not a straw" for feminine adornments like her mother: "how she dressed, how she treated people who came to lunch she did not care a bit" (MD 11). A mother's responsibility to her daughter is to raise her according to the standards of proper society. The only way a mother knows how to do this is to revert back to the way she herself was raised. When the daughter refuses to follow in those footsteps, the mother becomes frightened and resentful. Elizabeth is not mirroring her mother's image. As Peter Walsh 
observes, "She was at High School, at the inarticulate stage last time he was over, a round-eyed, pale faced girl, with nothing of her mother in her, a silent stolid creature, who took it all as a matter of course, let her mother make a fuss of her, and then said 'May I go now?"' (MD 77). Elizabeth is choosing to concern herself, not with the things her mother enjoys or deems important, but rather what the severe Miss Kilman finds interesting, evidenced in Elizabeth's forgetting her gloves as she prepares to go to the Army and Navy stores with Miss Kilman; Clarissa, who is passionate about gloves, would never have forgotten them. Clarissa feeling her daughter "forgetting" her and moving in a direction that she does not understand, panics and become flustered:

With a sudden impulse, with a violent anguish, for this woman is taking her daughter from her, Clarissa leant over the banisters and cried out, "Remember the party! Remember our party to-night!"

But Elizabeth had already opened the front door; there was a van passing; she did not answer. (MD 123)

The most important thing to Clarissa was her party; her daughter did not care about the party. She had already forgotten. Clarissa fears being replaced by Miss Kilman, and wants her daughter to be by her side as they receive their guests, but Elizabeth has chosen not to become her mother, but prefers to become a more independent young woman outside of traditional society.

Simone de Beauvoir discusses this relationship between a mother and her growing child and reveals that there can be some great anxieties if the mother feels overshadowed or cast aside by her daughter. This rejection is just another way for the married woman/mother to lose the miniscule control or power she possess in the private sphere:

The mother likes to rule alone over the feminine universe; she wants to be unique, irreplaceable; and now she finds herself reduced by her young helper to the status of one among many who merely perform a general functions.... It is even more intolerable, however, for her to have her daughter boldly assert herself as an other, 
an independent person. She systematically takes a dislike to the friends among whom her daughter seeks help against family oppression and who "work on her feelings"; she criticizes them. . . on the pretext that they have a bad influence" on her. Any influence that is not hers is bad. . . (SS 519-20)

If a daughter follows her mother's example, then the mother is justified in her own life. However, if a daughter diverts from her mother's path, the mother feels attacked and defensive. Elizabeth is diverting from Clarissa's example, and instead, walks along with Miss Kilman. Clarissa dislikes Miss Kilman for many reasons, but of course one reason being that her daughter enjoys Kilman's company, and this is very threatening to Clarissa. Elizabeth exhibits some characteristics of the New Woman as she rejects her mother's socially prescribed role of the perfect hostess and chooses instead to follow her own path crossing perpendicularly rather than running parallel to social conformity, for she still wears her gloves even though she forgets them at first, and she still goes home for the evening, but she does not care a fig for her mother's party. She attends the party because it is important to her mother, and Elizabeth is still her mother's daughter, regardless of her relationship with Miss Kilman: “'Are you going to the party tonight?' Miss Kilman said. Elizabeth supposed she was going; her mother wanted her to go. She must not let parties absorb her, Miss Kilman said, fingering the last two inches of a chocolate éclair. She did not much like parties, Elizabeth said" (MD 130). Regardless of her own desires for freedom from a life like that of her mother's, Elizabeth still attends the party, dressed very nicely, placing herself in front of the male gaze to be admired. However, Elizabeth does not enjoy this type of attention and would rather be left alone: And already, even as she stood there, in her very well cut clothes, it was beginning. ... People were beginning to compare her poplar trees, early dawn, hyacinths, fawns, running water, and garden lilies, and it made her life a burden to her, for she so much preferred to being left alone to do what she liked in the country, but they would compare her to lilies and she had to go to parties, and 
London was so dreary compared with being alone in the country with her father and the dogs. (MD 131)

While Elizabeth does what is expected of her by returning home and attending her mother's social event, she is mentally rejecting society and prefers the solitude and independence of the country. It is assumed that once Elizabeth is allowed to make her own life for herself, it will not mimic the social life of her mother.

Using Simone de Beauvoir's The Second Sex to re-read Woolf's women is beneficial in creating a striking contrast between what women were expected to be versus what women were becoming. The mixture of Woolf's women of propriety versus her women of non-conformity illustrates the shift that was happening within society. As the old guard held firm to the stagnant social standards of hierarchal structures of patriarchy, the war was causing cracks in the system, weakening it and allowing women to begin to emerge and change in society. Simone de Beauvoir's criticism of women in society gives not only a detailed account of who the oppressed woman was, but also a portrait of who the new woman needs to be. By presenting in the negative the way things were, Beauvoir creates an inverted blueprint for how things could be if women would refuse the pressures of the oppressive patriarchal society. When viewed through lens of The Second Sex, it seems as though Woolf not only creates the traditional woman, but also depicts that woman alongside a budding New Woman, fictionalizing the same sort of blueprint that Beauvoir creates years later in France. So who is this New Woman? 


\section{CHAPTER FIVE: \\ (AN)OTHER GENDER: ONE IS NOT BORN BUT RATHER BECOMES. . .}

The turmoil caused by the First and Second World Wars as they ravaged the European Landscape is undeniable. The human, as well as the financial loss to the fighting nations, including France and Great Britain, changed the face of Europe so much

so that the phrase "the lost generation" was created to refer to the people who died during these violent times. The social and political face of France and Great Britain was forced to shift as women changed their roles in traditionally conservative and male-dominated societies. In order to make up for the loss of life as so few men returned from the battle front, women moved out of the home and into the work place in large numbers to keep the economy and the war machine producing. This role reversal alone created a gap in how men and women were able to describe their experiences; there were few precedents a modern individual could draw upon to help describe the new experiences lived by these damaged men and working women. New methods of defining the self and its experiences were needed as those who survived the fighting tried to crawl out from under the rubble of war and into a society that was changed forever.

The binary gender system that had dominated the ways men and women defined themselves or each other was no longer useful in this new world. Women were proving every day that their biological make-up did not inhibit their abilities to work outside of the home. As women learned to maneuver through the still male-dominated world, they began to see a problem in how they were (un)able to describe their lives and 
experiences.Were they still "women" in society as defined in traditional terms? The biology had not changed, for human females had not lost their reproductive organs, but their freedom to move about in a world that had previously been closed off, or forbidden to them (including contraception) was now opening, and suddenly, these people who were biologically female were in need of talking about themselves apart from the traditional roles of marriage and motherhood. They were not men, of course, but they were living and functioning productively in a man's world. They were still biologically female but were no longer just gendered "women" in the traditionally social sense of wife and mother only. There arose a need for a different way in which to describe women in the world. To label a woman as "Other" was problematic because the label "Other" required a "norm" against which to establish the "Other." This insufficient method of definition focused upon the binary gender system in which there are only two options, man(norm)/woman(other), and all of human experience was expected to fit within one of those two categories. However, as the world changed, so did the need for new categories, or perhaps, more categories from which to choose and describe human experience.

Virginia Woolf and Simone de Beauvoir recognized the need to develop ways in which a human being can express an experience without automatically filtering that experience through the category of gender. Therefore, they attempted to define something else, but not necessarily something "Other" as so many had done before. This new idea is (An)Other gender in which socially defined gender is obsolete; it is the individual's choice to decide how to filter an experience. This is an idea that centers around Beauvoir's notion of existential freedom as she viewed Sartre's premise of freedom as flawed, as well as Woolf's phenomenological representation of experience in Moments of 
Being, A Room of One's Own, Three Guineas, and Orlando. According to Nancy

Topping Bazin in Virginia Woolf and the Androgynous Vision:

Virginia Woolf felt that neither an individual nor an age can finds its point of equilibrium without frankly confronting the exact nature of opposing forces. Thus, her interest in what it means to be a male or a female was related to her quest for the self or the point of balance that would stabilize her personality and give her the sense of wholeness and unconsciousness which characterizes the androgynous writer. (3-4)

According to Woolf in A Room of One's Own, men and women both, in order to be successful in a new world must not consider their own individual sexes but rather should work from both at the same time: "It is fatal to be a man or a woman pure and simple; one must be woman-manly or man-womanly. It is fatal for a woman to lay the least stress on any grievance; to plead even with justice any cause; in any way to speak consciously as a woman. And fatal is no figure of speech; for anything written with that conscious bias is doomed to death. It ceases to be fertilized" (AROO 104). Woolf's focus on the androgynous spirit for both men and women is important to consider not just in the context of A Room of One's Own, but in her whole feminist argument in which she calls for the transformation of thinking about and relating to each other as experiential human beings rather than just men and women defined and even hindered by their genders. Keeping in mind the idea of being man-womanly or woman-manly, we will turn to Woolf's Orlando in which the hero becomes the heroine as he wakes one morning and realizes that he is now a woman, and other than his/her anatomy, very little has changed, therefore making gender inconsequential in the realm of human experience. Utilizing particular works of Woolf and Beauvoir within their historical context allows for a better understanding of the shifts taking place for both men and women in society with respect to their gendered roles publicly and privately. As Robert Poole states in The Unknown 


\section{Virginia Woolf:}

In the same way one could risk the aphorism that novels are not exact copies of, or transcripts from, a life, but there is a sense in which they are perilously like them. All the more perilously like them, for straining not to be like them. In the strain away from the lived particular, there is the symbolic substitution, shift or displacement, which tells more, if that were possible, about the lived particular than that particular could itself have offered. (5)

The works of Woolf and Beauvoir allow for an historical understanding of the changes happening within society and the needs of the people living in a changing world. New methods of defining and understanding human beings and their experiences in the modern world were necessary. The antiquated modes of definition were no longer useful in expressing what it meant to be in a world that had been forever changed by the devastation of two world wars.

\section{Ideological State Apparatus: Can She Really Be Free?}

Simone De Beauvoir's idea of existential freedom is different from that of Sartre's, for Beauvoir contends that from the moment of birth, one is thrust into a societal stratum already created and agreed upon by one's predecessors. Woolf too comments upon this idea in $A$ Room of One's Own in which she argues that women must look back to women of the past to gain a sense of history, for the male tradition has pushed women to the margins of history:

For we think back through our mothers if we are women. It is useless to go to the great men writers for help, however much one may go to them for pleasure.

Lamb, Browne, Thackeray, Newman, Sterne, Dickens, De Quincey-whoever it may be-never helped a woman yet, though she may have learnt a few tricks of them and adapted them to her use. The weight, the pace, the stride of a man's mind are too unlike her own for her to lift anything substantial from his successfully. The ape is too distant to be sedulous. (AROO 104)

Woolf's comments on the lack of female literary history can be linked to Louis 
Althusser's Ideological State Apparatus (ISA) which is a useful theory to consider when contemplating the place of woman at the time of Woolf and Beauvoir both in the home and as an emerging figure in society. The problem that ISA points out is that a female child being brought up in a community has little opportunity to create change within the narrow duality of the male/female struggle embedded in a particular community. This idea is also discussed in Peter Berger's The Sacred Canopy: Elements of a Sociological Theory of Religion, in which he claims:

Society is a dialectic phenomenon in that it is a human product, and nothing but a human product, that yet continuously acts back upon its producer. Society is a product of man. It has no other being except that which is bestowed upon it by human activity and consciousness. There can be no social reality apart from man. Yet it may also be stated that man is a product of society. Every individual biography is an episode within the history of society, which both precedes and survives it. Society was here before the individual was born and it will be here after he has died. (3)

The cyclical nature of the production of society that Berger discusses, and the people who succumb to societal pressures and institutions, are the primary reasons for the continual oppression of human beings in society.

In his essay, "Ideology and Ideological State Apparatuses," Louis Althusser discusses ISAs and their roles in tricking an individual into submission to a particular institution. This is necessary within a society that wishes to perpetuate itself and its interests. Therefore, a ruling class will utilize the institutions in society to maintain power by setting up rituals and customs within those institutions that people will follow because those people are ideologically committed to those institutions. He writes, "In order to exist, every social formation must reproduce the conditions of its production at the same time as it produces, and in order to be able to produce. It must therefore reproduce: 1 . the productive forces, 2. the existing relations of production." In order to continue its 
domination, the patriarchy, for example, must continue reproducing the power structure in society in order to maintain its power structure in society. Berger explains the how society maintains itself so that the production and reproduction of society and its power structures are able to continue:

Externalization is the ongoing outpouring of human being into the world, both in the physical and the mental activity of men. Objectivation is the attainment by the products of this activity. . . of a reality that confronts its original producers as a facticity external to and other than themselves. Internalization is the reappropriation by men of this same reality, transforming it once again from structures of the objective world into structures of the subjective consciousness. (4)

As human beings act in the world, they create their own reality and that reality turns the actions from something chosen by the individual into something dictated and defined by society. As the producers produce the world, the world reproduces that which allowed production to occur in the first place. This is the cyclical and potentially oppressive nature of human society.

Althusser makes a distinction between the different state apparatuses, claiming that there is the (repressive) state apparatus and the ideological state apparatus:

The [repressive] State Apparatus (SA) contains: the Government, the Administration, the Army, the Police, the Courts, the Prisons, etc., .... Repressive suggests that the State Apparatus in question 'functions by violence' at least ultimately (since repression, e.g. administrative repression, may take nonphysical forms).... I shall call Ideological State Apparatuses a certain number of realities which present themselves to the immediate observer in the form of distinct and specialized institutions. (Althusser)

The SAs' violence is manifest by the government in the form of fear and oppression. Not only is the violence physical, but social as well. Althusser goes on to list what he considers the ISA institutions which include religious institutions, educational institutions, political parties, trade unions, public media/communications, and the family: 
As a first moment, it is clear that while there is one (Repressive) State Apparatus, there is a plurality of Ideological State Apparatuses. Even presupposing that it exists, the unity that constitutes this plurality of ISAs as a body is not immediately visible. As a second moment, it is clear that whereas the unified - (Repressive) State Apparatus belongs entirely to the public domain, much the larger part of the Ideological State Apparatuses (in their apparent dispersion) are part, on the contrary, of the private domain. Churches, Parties, Trade Unions, families, some schools, most newspapers, cultural ventures, etc., etc., are private.

Like Althusser, Berger also discusses the man-made "non-material elements of culture" as he refers to specific institutions and practices human beings create in society. Berger writes, "Man invents language and then finds that both his speaking and his thinking are dominated by its grammar. Man produces values and discovers he feels guilt when he contravenes them. Man concocts institutions, which come to confront him as powerfully controlling and even menacing constellations of the external world" (4). What Berger does not seem to mention is that it is the majority of the people who are forced to succumb to the powers of the social elements, but not necessarily all people. Those who hold power positions in society are the ones who have dictated the development of many institutions, and these institutions were designed in order to maintain the power structures that benefit some within society. Through these elements of society, the few can oppress the masses.

It is within the private ISA's that oppression can really occur, for if a person ignores one of these particular ISA's (like the family or the church), then that person can completely alienate his or her self from everyone and everything that person knows or understands; this person could become a social outcast for ignoring the rules or roles defined by the powerful ISA. As people are born into specific ISAs, their places within the community are already defined by those seeking (consciously or unconsciously) to 
perpetuate what they consider their own traditions and customs. According to Althusser, the traditions that people so unwittingly believe are of their own making and choosing have actually been thrust upon them in ways that allow no real choices. If a person chooses to throw off those traditions, that person is made to feel guilty or abnormal. Althusser writes:

The individual in question behaves in such and such a way, adopts such and such a practical attitude, and, what is more, participates in certain regular practices which are those of the ideological apparatus on which 'depend' the ideas which he has in all consciousness freely chosen as a subject. If he believes in God, he goes to Church to attend Mass, kneels, prays, confesses, does penance .... If he believes in Duty, he will have the corresponding attitudes, inscribed in ritual practices 'according to the correct principles'.... (Althusser)

The ISA guidelines by which to act have been created long before many participants were even born; babies are born into the ISA's of their parents and thus are expected, taught, and raised to uphold those same traditions. Therefore, that baby has no choice into what ISA he or she is born and raised, but may never become aware that there were actually no choices:

Throughout this schema we observe that the ideological representation of ideology is itself forced to recognize that every 'subject' endowed with a 'consciousness' and believing in the 'ideas' that his 'consciousness' inspires in him and freely accepts, must 'act according to his ideas', must therefore inscribe his own ideas as a free subject in the actions of his material practice. If he does not do so, 'that is wicked'. Indeed, if he does not do what he ought to do as a function of what he believes, it is because he does something else, which, still as a function of the same idealist scheme, implies that he has other ideas in his head as well as those he proclaims, and that he acts according to these other ideas, as a man who is either 'inconsistent' ('no one is willingly evil') or cynical, or perverse. (Althusser)

People may believe that they act as free subjects, but if they choose not to act according to their prescribed ideological state apparatus' rules, then they feel "perverse." According to Berger, society desires to be taken for granted, or in other words, not considered, for 
when people begin to consider their world, they may become discontent and begin to actively seek change:

The social world intends, as far as possible, to be taken for granted. Socialization achieves success to the degree that this taken-for-granted quality is internalized. It is not enough that the individual look upon the key meanings of the social order as useful, desirable, or right. It is much better (better, that is, in terms of social stability) if he looks upon them as inevitable, as part and parcel of the universal "nature of things." If that can be achieved, the individual who strays seriously from the socially defined programs can be considered not only a fool or a knave, but a madman. (24-5)

In order not to be outcasts in society, people who secretly question societal institutions might not publicly condemn them so as not to alienate themselves from the social world. For fear of being categorized as "perverse," as Althusser put it, people conform to social regulations instead and remain within the confines of their ideological state apparatuses. The problem here is that they may have no idea of the cyclical and oppressive nature in which they live, and therefore have no way of escaping. In actuality, people even contribute to their own oppression by perpetuating the ISA in which they live and which oppresses their own subjectivity. One is reminded of both Virginia Woolf and Simone de Beauvoir's discussions of women in oppressive societies who force the same oppressive behaviors upon their young daughters in an attempt to validate their own lives. This is how the cycle is able to continue and how the powerful classes are able to maintain their dominance.

Simone de Beauvoir's discussion of oppression in The Ethics of Ambiguity echoes in Althusser's argument as Beauvoir states, "The tendency of man is not to reduce himself, but to increase his power" (92). Beauvoir believes that there are two "clans" of human beings in society: "those who enlighten mankind by thrusting it ahead of itself and 
those who are condemned to mark time hopelessly in order merely to support the collectivity" (Ethics 83). Beauvoir's argument concerning freedom differs from Jean Paul Sartre's, insofar as she argues that an oppressed person in society will not have the same opportunities to pull him or herself out of the oppressive state as someone who does not have to contend with the same oppression. Althusser similarly argues that in order to maintain power, the producer/oppressor must continue reproducing the environment that allows the production to be successful. Beauvoir continues in her argument by claiming that people cannot free themselves from an oppressive state if they do not understand their own oppression and have no power with which to free themselves. Only after the oppressed are made aware of their situation and are taught how they may go about their own release can the oppressed in a society actually be free. Beauvoir writes, "If I want the slave to become conscious of his servitude, it is both in order not to be a tyrant myself-for any abstention is complicity, and complicity is in this case tyranny-and in order that new possibilities might be opened to the liberated slave and through him to all men" (Ethics 86). In order to change the oppressive state, one must change the environment that allows the oppressive state to exist and function successfully. Those who participate in the oppressive state, not just the creators, but some of the oppressed as well, are in some respects complicit in their actions within the oppressive state. Those mothers who propagate the same restrictions they resented when they were young upon their own young daughters are in many ways accomplices in the success of the oppressive situation which they perpetuate. Berger touches upon the complicity of social beings in the creation and reproduction of social roles that they themselves may resent:

The institution is there, external and coercive, imposing its predefined patterns upon the individual in this particular area of life. The same objectivity belongs to 
the roles that the individual is expected to play in the institutional context in question, even if it should happen that he does not particularly enjoy the performance. ... Thus he can even say that he does not like to perform this or that detail of the role, but must do so against his will-because the objective description so dictates. Furthermore, society not only contains an objectively available assemblage of institutions and roles, but a repertoire of identities endowed with the same status of objective reality. Society assigns to the individual not only a set of roles but a designated identity. (19)

Berger describes the power of society's ability to pressure people to conform to their designated roles agreed upon by the powerful members of a society. Even if a person is unhappy with his or her prescribed role in society, he or she will continue to propagate the role because that is how society has defined that individual person. Without the role, the person is without definition. Berger goes on to explain how not only does society dictate the definition of the role a person is supposed to play in the world, but also dictates how that person interprets experiences within that role. Conveniently built into the structure of a society is the ability to pre-define the experiences of the beings within that society:

The socially constructed world is, above all, an ordering of experience. A meaningful order, or nomos, is imposed upon the discrete experiences and meanings of individuals. To say that society is a world-building enterprise is to say that it is ordering, or nomizing, activity. The presupposition for this is given, as has been indicated before, in the biological constitution of homo sapiens. Man, biologically denied the ordering mechanisms with which the other animals are endowed, is compelled to impose his own order upon experience. (19)

Experience is filtered and defined by society, and the societies of both Woolf and Beauvoir were dominated by patriarchy. Therefore, the experiences of women had always been dictated and defined by the male norm, marginalizing female or human experience as other.

Virginia Woolf creates a female character whose experiences are dictated and 
defined by a patriarchal society, despite her having all the same abilities as her male counterpart. In the end, because she refused to succumb to the prescribed ISAs of her society, she was doomed to a life of despair. The reason Woolf cannot speak to a particular woman in the world but rather has to imagine a female example is because "facts are so hard to come by," meaning that female history is so scattered, marginalized, or absent (AROO 46). Woolf's discussion of Judith Shakespeare in A Room of One's Own illustrates the idea that a woman with as much talent as a man would have been historically unable to overcome the social limitations set in place well before her birth.

Woolf imagines Judith Shakespeare as a response to the statement that "Women cannot write the plays of Shakespeare" (AROO 46). Woolf begins her response to this statement by detailing all of the privileges that Shakespeare enjoyed simply because he was a male, including his schooling where he would have "learnt Latin-Ovid, Virgil, and Horace—and the elements of grammar and logic" (AROO 46). She goes on to explain his wild adolescent ways, his young escapades, and then his marriage to "a woman in the neighborhood, who bore him a child rather quicker than was right" ( $A R O O$ 46-7). Because of this, Shakespeare left for London to pursue his theatrical aspirations: "Very soon he got work in the theatre, became a successful actor, and lived at the hub of the universe, meeting everybody, knowing everybody, practicing his art on the boards, exercising his wits on the streets, and even getting access to the palace of the queen" (AROO 47). The young Shakespeare is allowed any opportunity he is willing to seek, and is ultimately successful at his endeavors because he has had the proper education and the freedom to explore and become confident in himself and his abilities. As an adult, he is as adventurous as the wild boy who "poached rabbits" and "shot deer" 
(AROO 46).

While Shakespeare is allowed to pursue whatever goals he sets for himself, his equally talented and energetic sister faces a much different future. As Woolf writes in her polemical work Three Guineas, "The very word 'society' sets tolling in memory the dismal bells of a harsh music: shall not, shall not, shall not. You shall not learn, you shall not earn; you shall not own; you shall not-such was the society relationship of brother to sister for many centuries" (TG 105). To use Althusser's term, Judith Shakespeare was tragically constrained by her female roles as defined by the ISAs into which she was born. Her educational experience was negligible in comparison to her brother's, and she became adept at hiding her reading and writing so as not to be reprimanded by her parents whose goal was to perpetuate the cycle of female oppression, regardless of how much they cared for their young daughter; her mother and father were complicit and instrumental in her oppression. Woolf describes the life of Judith Shakespeare, starting with her lack of formal education: "She was not sent to school. She had no chance of learning grammar and logic, let alone of reading Horace and Virgil. She picked up a book now and then, one of her brother's perhaps, and read a few pages. But then her parents came in and told her to mend the stockings or mind the stew and not to moon about with books and papers" (AROO 47). Pointing out that the books Judith might read from time to time probably belong to her brother reminds us that women were part of a minor literary tradition and owned very little of what was written. According to her parents, and society, those books and the ideas within them did not belong to Judith. Woolf continues, describing the measures Judith would use to please her parents:

[Her parents] would have spoken sharply but kindly, for they were substantial people who knew the conditions of life for a woman and they loved their 
daughter-indeed, more likely than not she was the apple of her father's eye.

Perhaps she scribbled some pages up in an apple loft on the sly, but was careful to hide them or set fire to them. (AROO 47)

Understanding the world in which their daughter was living, and unconsciously agreeing to abide by the laws of the ISA's that they themselves took for granted, Judith's parents insisted that it was best she comply with the standards set by society. What chance did Judith have but to escape the confines of the private sphere where she was guarded by her parents? She had to leave. Woolf describes the predicament a teen-aged Judith found herself in as her parents tried to force her to marry a man she did not love: "She cried out that marriage was hateful to her, and for that she was severely beaten by her father" ( $A R O O 46$ ). Judith's audacity to go against the family, the patriarchy, and the church was almost a crime, and her father punished her for her defiance of his will.

Judith left her father's house, choosing like her brother to rely on her talents and make a life of her own. However, because of Judith's sex, she was rejected, laughed at, preyed upon, seduced, and impregnated. Woolf writes, "She could get no training in her craft. . . At last-for she was very young, oddly like Shakespeare the poet in her face. . . at last Nick Greene the actor-manager took pity on her; she found herself with child by that gentleman and so-killed herself one winter's night and lies buried at some crossroads. ..." (AROO 48). Judith's inability to survive on her own talents and to make her own living forced her to revert back to the traditional standard of relying upon a man for support. However, instead of support, she became prey, and once again suffered because of her biology when she became pregnant. Ultimately, Woolf's argument is that Judith's demise was the result of her sex. Her downfall was due to her societal limitations and biology rather than her individuality. Succumbing to the binary gender system, what 
amount of responsibility and power did a woman like Judith possess in the creation of her own subject position? How ultimately could she go about creating change when the rules of the social system were dominated by the patriarchy?

\section{(An)Other Gender: Orlando and A Third Sex}

Simone de Beauvoir's phenomenological refutation of the biological nature of gender and her arguments against the use of biology as weapon against female emancipation is an important part of defining (An)Other gender. As a feminist phenomenologist, Beauvoir works with how lived female experience, and the ways in which women are defined by their bodies, affect the way women experience the world in general. Woolf, too, uses the idea of gender as something that can be manipulated. Both women see gender as something not "essential" or inherent. Woolf believed that a woman should not remain in the patriarchal society with the intention of propagating the status quo. She did not want women to become men, and she also was not interested in women remaining women as they were defined within current society, but rather she believed that each human being should cultivate an androgynous quality by becoming "manwomanly or woman-manly." Simone de Beauvoir noted that because women had no part in creating their social situation, they therefore lacked the tools or resources necessary to change their positions in regard to money, education, and political power. Woolf also addressed this issue in Three Guineas when she argued that there was no point in women using the current society to fight for position. Why write a letter to the editor when the editor is a man supporting patriarchal models of male domination and female oppression: ... although it is true that we can write articles or send letters to the Press, the control of the Press - the decision what to print, what not to print- - is entirely in 
the hands of your sex.... Thus all the weapons with which an educated man can enforce his opinions are either beyond our grasp or so nearly beyond it that even if we used them we could scarcely inflict one scratch. (TG 12)

The only way to possess true freedom was to become not a woman as dictated by patriarchal society, but rather something else that was not originally defined in opposition to a man. As stated in her 1983 interview, Beauvoir believed that "when women really begin to consider liberating themselves seriously, they will take more of an interest in politics" (Bair 28). How are women to effect social change? Not by taking up a political office within the current society, for that would encourage women to mimic male dominance, destruction, and oppression. As Beauvoir stated in the interview, "She can make war as well as any man," (Bair 27). Woolf too states that women are just as capable of becoming as corrupt as males in aspiring towards political and social domination.

In her polemical work, Three Guineas, Woolf makes an argument against women's joining the male-dominated society, even if they had the means to do so. For while it is important for women to be able to sustain their own lives and careers without the support of men, to enter into and support society as it was would be to continue supporting an oppressive state. Woolf attacks society on behalf of both men and women:

Inevitably we look upon society, so kind to you, so harsh to us, as an ill-fitting form that distorts the truth; deforms the mind; fetters the will. Inevitably we look upon societies as conspiracies that sink the private brother, whom many of us have reason to respect, and inflate in his stead a monstrous male, loud of voice, hard of fist, childishly intent upon scoring the floor of the earth with chalk marks, within whose mystic boundaries human beings are penned, rigidly, separately, artificially....[He] enjoys the dubious pleasures of power and dominion while we, "his" women, are locked in the private house without share in the many societies of which his society is composed. (TG 105)

Woolf describes the societal trap in which both men and women find themselves, but women, unlike men, benefit very little from the societal structure which has been 
designed to uphold patriarchal interests. Woolf addresses these interests when she claims that women should be warned away from joining the destructively cyclical patriarchal society and should instead develop an Outsider's Society:

It seems wrong for us rationally and impossible for us emotionally to fill up your form and join your society. For by doing so we should merge our identity in yours; follow and repeat and score still deeper the old worn ruts in which society, like a gramophone whose needle has stuck, is grinding out with intolerable unanimity "Three hundred millions spent upon arms." (TG 105)

Woolf's mention of the war machine created and upheld by patriarchal society is one important reason why Woolf is so uninterested in women adopting the values of the world as it is. For men have created a destructive environment as Woolf watched the First World War destroy so many lives, and she does not want women to be seduced by the power a war machine can provide. Instead, Woolf argues for something else, something outside of the norm where people are able to act in new ways and through new definitions. To be a man in society acting out male gender roles was just as useless as being a woman in society, in Woolf's opinion. In her novel Orlando, she seems to work through what can be considered an alternative to the binary gender system in society, an alternative that focuses first on human experience rather than on gendered human experience. In the article, "Would the Real Virginia Woolf Please Stand up? Feminist Criticism, the Androgyny Debates, and Orlando," Lisa Rado argues "rather than a novel about identity, [Orlando] is a novel about identity crisis, gender trouble, and cultural change that ultimately presents not 'Orlando' or 'Virginia Woolf' but rather the struggle behind both artists' attempt at 'being" (152). Orlando reflects the anxieties felt in reaction to the shifting gender roles of both men and women. How were men and women supposed to act in society without defined roles for each? 
Simone de Beauvoir stated famously in The Second Sex, "One is not born, but rather becomes a woman" (SS 267). Virginia Woolf seemed to represent this idea in her portrayal of the title character Orlando. As the novel begins, we see a young, male Orlando acting as any young man should, violently, aggressively, and with the confidence that what he is doing is in accordance with how he was raised and how he should act as a man. The violent scene depicts a young man justified in his brutal actions: "He- for there could be no doubt of his sex, though the fashion of the time did something to disguise it - was in the act of slicing the head of a Moor which swung from the rafters. ... Orlando's father, or perhaps his grandfather, had struck it from the shoulders of a vast Pagan. ..." $(O 13)$. Within the opening lines of the novel, the reader is introduced to two very important patriarchal activities and institutions. The first is the imperialistic war machine which plagues the Other with violence and destruction. The second is the Church, as Orlando's family killed "pagans" in the name of the Christianity. Looking back to Althusser once again, we see the political and religious ISAs at play here, and Orlando is reproducing the environment in which these particular ISAs thrive. Woolf continues:

Orlando's fathers had ridden in fields of asphodel, and stony fields, and fields watered by strange rivers, and had struck many heads of many colours off many shoulders, and brought them back to hang from the rafters. So too would Orlando, he vowed. But since he was sixteen only, and too young to ride with them in Africa or France, he would steal away from his mother and the peacocks in the garden and go to his attic room and there lunge and plunge and slice the air with his blade. $(O 13)$

Orlando plans to follow in his forefathers' footsteps and continue the perpetuation of patriarchal domination. He practices violence in his attic so that when the time comes for him to slice his own pagan heads, he will be well prepared. 
Orlando's life until he is thirty years of age takes a patriarchal path rich with power and position: "He played a most important part in the public life of his country.... We know that he discharged his duties to admiration. ... We know that he had a finger in some of the most delicate negotiations between King Charles and the Turks-to that, treaties in the vault of the Record Office bear testimony $(O 119)$. His political powers allow him to live a life free from oppression, and he is allowed to oppress others for his own personal gain and pleasure. However, one morning, something extraordinary happens to Orlando as he becomes a person no longer in position of power, but rather changes and becomes a member of the oppressed class. Orlando, as Beauvoir might say, "was not born, but rather becomes a woman" (SS 267). Woolf writes, as Orlando wakes one morning: "He stretched himself. He rose. He stood upright in complete nakedness before us, and while trumpets pealed Truth! Truth! Truth! We have no choice left but confess- - he was a woman. ... No human being, since the world began, has ever looked more ravishing. His form combined in one the strength of a man and a woman's grace" (O 137-8). Orlando is now a woman, but s(he) realizes that the person within, the self, has not changed. Although the biology has shifted from male to female, all experiences past and present are still with Orlando, regardless of his/her biological sex. For Orlando, the change meant little when it came to filtering or defining experiences: "Orlando had become a woman - there is no denying it. But in every other respect, Orlando remained precisely as he had been. The change of sex, though it altered their future, did nothing whatever to alter their identity. ... His memory. . . her memory then, went back through all the events of her past life without encountering any obstacle" $(O 139)$. Viewing Woolf's Orlando from a phenomenological standpoint, Orlando is the embodiment of 
experience outside of gendered considerations. And while others may see Orlando as either a man who is now a woman or a woman who used to be a man, such gender constructions do not matter if Orlando believes that they are inconsequential. His/her interpretation of the experiences that he/she had endured is all that has any meaning when considering not a man and not a woman, but rather (An)Other gender altogether. For Orlando is not just androgynous. Orlando is not both a man and a woman, but essentially neither. As Rado argues:

It is not insignificant that of all Orlando's physical attributes, the only ones that the narrator describes are his/her face and legs, and nothing in between. Instead, throughout the novel we are presented with an elaborate series of veils which serve to distract and deflect our attention from Orlando's biological sex in order to preserve his/her androgynous subject-position from the imposition of patriarchal norms. Even from the first page of the novel, he appears draped in clothes which "did something to disguise" the definitiveness of his sexual body. (153)

Less important is Orlando's biological sex and more important is his/her experiences and how he/she interpret those experiences. To deviate from describing the new female Orlando's female anatomy both in sexual or reproductive terms, the narrator in part delivers her from the constraints placed upon women for those very physical attributes. However, Orlando is still a person living within a society that retains those gendered definitions.

As Woolf continues chronicling Orlando's experiences, we see "her" now experiencing the world in a woman's body but having the ability to interpret those experiences neither as a woman nor a man. Instead, Orlando experiences the world as a human being who is defined by those outside of herself, who are interested only in placing the societal constraints upon her that females must endure. Again, these constraints come from outside of Orlando, not from within her own interpretation: 
"But what used we young fellows in the cockpit of the Marie Rose to say about a young woman who threw herself overboard for the pleasure of being rescued by a bluejacket?" she said. "We had a word for them. Ah! I have it...." (But we must omit that word; it was disrespectful in the extreme and passing strange on a lady's lips.) "Lord! Lord!" she cried again at the conclusion of her thoughts, must I then begin to respect the opinion of the other sex, however monstrous I think it? $(O$ 156).

Orlando is coming to terms with the rules of society placed upon a person who has female biology regardless of her actual capabilities. Even if a human female can swim, she must pretend that she cannot so that she can be rescued by a gallant male. Orlando begins to resent this but also begins to come to terms with "his" past complicity with such standards:

She remembered how, as a young man, she had insisted that women must be obedient, chaste, scented, and exquisitely appareled. "Now I shall have to pay in my own person for those desires," she reflected; "for women are not (judging by my short experience of the sex) obedient, chaste, scented, and exquisitely appareled by nature. They can only attain these graces. . by the most tedious discipline. $(O$ 156-7)

Orlando has realized that all of the truths he placed upon women are in fact invalid as she experiences the falsities placed upon her own person and recognizes them as unjustified. Orlando continues, "A pox on them!" she said, realizing for the first time, what, in other circumstances, she would have been taught as a child, that is to say, the sacred responsibilities of womanhood" $(O$ 157). Reminiscent of Woolf's Judith Shakespeare, had Orlando been born a human female, her life would have developed differently not because of her (in)abilities, but because of the societal standards into which she would have been born and forced to obey. Woolf"s mention of the "sacred responsibilities of womanhood" seems less about the so-called joys of being a woman and more about the social restrictions forced upon a particular sex in correspondence with the customs and rituals dictated by particular ISA's. Orlando resents the guilt she is made to feel over 
showing "an inch or two of calf," distracting a sailor, causing him to almost plummet to his death: "And she fell to thinking what an odd pass we have come to when all a woman's beauty has to be kept covered, lest a sailor may fall from a mast-head" $(O 157)$. Orlando's ability to move back and forth between the consciousnesses of both a male subject and a female subject, to interpret the experiences she had as she was and is gendered in society, makes her less an object and more an observer as she interprets her experiences with time, both past and present, through biology, both male and female, and then as just Orlando, something else, (an)other being altogether:

She was censuring both sexes equally, as if she belonged to neither; and indeed, for the time being, she seemed to vacillate; she was man; she was woman; she knew the secrets, shared the weaknesses of each. It was a most bewildering and whirligig state of mind to be in... Thus it is no great wonder if, as she pitted one sex against the other, and found each alternately full of the most deplorable infirmities, and was not sure to which she belonged. ... $(O$ 158-9)

Orlando had the benefit or misfortune of experiencing both genders and realizes that neither man nor woman is ideal, for both are laden with pressures from the outside, forcing the self within to act and interpret actions according to social guidelines. Orlando begins to identify more with the womanly aspect of her experiences; she makes a choice between the male and female lens through which she will interpret her experiences. Biological sex is not the determining factor of the self, but rather for Orlando's self, choice is inherent:

It was a change in Orlando herself that dictated her choice of a woman's dress and of a woman's sex.... Different though the sexes are, they intermix. In every human being a vacillation from one sex to the other takes place, and often it is only the clothes that keep the male or female likeness, while underneath the sex is the very opposite of what is above. $(O 188-9)$

Clothing is socially dictated; society decides what is appropriate or inappropriate for men and women to wear. According to Woolf, the outside gaze is a powerful element in 
society, for it defines who a person is without any consideration of what happens within the self. However, according to Sandra Gilbert and Susan Gubar in No Man's Land: The Place of the Woman Writer in the Twentieth Century:

Orlando ... really is androgynous ... in the sense that she has available to her a sort of wardrobe of male and female selves. Making herself up daily out of such costumes, Orlando rejoices in a society where there need be no uni-forms, for indeed (as if confusing nakedness and costume) Woolf remarks that Orlando's own "form combined in one the strength of a man and a woman's grace." (2: 344-5)

Orlando takes control over her appearance for she has the ability to appear however she pleases and uses her experiences as both male and female to define herself at a given moment. What is important for Woolf is the moment and how an individual defines a particular moment. This idea is expressed in "Modern Fiction":

Look within and life, it seems is very far from being 'like this.' Examine for a moment an ordinary mind on an ordinary day. The mind receives a myriad impressions-trivial, fantastic, evanescent, or engraved with the sharpness of steel. ... The moment of importance came not here but there. . . Life is not a series of gig lamps symmetrically arranged; life is luminous halo, a semitransparent envelope surrounding us from beginning of consciousness to the end. (CR 149-50)

For Orlando, importance is being placed on the moments as she experiences them and reflects back upon them. For once she has changed sexes, she is able to have a new understanding of her past experiences and interprets those experiences through a new filter and decides what is important to remember and what is insignificant. Woolf's phenomenological experimentation with Orlando's sex gives rise to the argument of (An)Other gender, for Orlando has experiences with both sexes and therefore is never really one sex. She can choose which gender she will identify with, for she has the ability to pull from both male and female, manly and womanly experiences. She can be both, one, the other, or (An)Other altogether. Nancy Bazin in Virginia Woolf and the 
Androgynous Vision states that "the masculine and the feminine should be balanced but not fused" (23). Nancy Taylor, in her article "Erasure if Definition: Androgyny in Mrs. Dalloway," argues that Woolf utilizes a type of "balanced" androgyny rather than "fused" androgyny: "Woolf accepts different tendencies in men and women that may be both essential and learned. ... Her point, however, is not to limit men and women to separate ways of knowing, but to recognize differences between them, each learning from what the other has to offer-an openness beneficial to artistic creation" (368). While Bazin does not go on to explain the differences between fused and balanced androgyny, Marilyn Farwell lays out the different characteristics of each in her article "Virginia Woolf and Androgyny." She argues, "If androgyny is a balance of male and female principles—and in Woolf's case these principles would be rationality and intuition respectively, or as Bazin suggests, knowing by apartness and knowing by togetherness- - then the male and female sides of the brain would interact without either side dominating or subsuming the other" (435). She goes on to explain the negative aspects of "fused" androgyny:

The notion that androgyny is a union, usually mystical, of two people, two qualities or two principles, however, leads to a radically different critical tool. Width and breadth of perception are no longer the criteria, but rather a single mode of response and knowing is validated. In this case, androgyny would be identified with one supposedly asexual evaluative quality, usually one which has subsumed and defined the opposite. In critical terms, either intuition or reason could become the dominant critical quality. But because the universal is most often defined with whatever is male, this definition of androgyny can be and has been another means for demanding that women write like a man. (436)

Nancy Taylor agrees with Farwell's negative portrayal of fused androgyny and further explains the idea:

This concept of androgyny typically begins with a creation of binary oppositions where the Other (female) is defined as the negative, in opposition to the qualities of the One (male). The struggle for supremacy becomes a struggle for the victory of good over evil; but as long as this notion exists, the Other will be repressed 
through destruction, or transformation into something safe. This concept of androgyny, which identifies traditionally male values with the universal, is certainly damaging to a woman's self-image and should be resisted. (368)

Taylor, Farwell, and Bazin all agree that balanced androgyny would benefit both men and women more in that neither one would be dominated or blotted out by the other but would rather be, in Woolf's terms, man-womanly or woman-manly, leaving behind the rules of biological determinism that relegates men and women to separate spheres of society.

Simone de Beauvoir too denies biological determinism and argues against the predetermined paths created for human beings based solely on sex. In The Second Sex, she states that it is through living in a society that is not of her own making that a woman "becomes a woman" and this is different from being born a human female. For being female points to reproductive capabilities that are only possible for a person who has the necessary organs. However, to be defined as a woman in society is dictated not by her capabilities, but by a power structure that defines her roles without considering what she can or cannot achieve. As Beauvoir writes, "No biological, psychological, or economic fate determines the figure that the human female presents in society; it is civilization as a whole that produces this creature, intermediate between male and female eunuch, which is described as feminine" (SS 267). Beauvoir believes that women are imprisoned in their sex and are surrounded by the bars of their inferior physical strength and lack of historical dominance, for how can women change their place in an oppressed society if they have very little history from which to draw inspiration or enlightenment? Woman is always defined against what she is not, or in other words "him." As Beauvoir writes, "She is a womb, an ovary; she is female - this word is sufficient to define her." (SS 3). 
Beauvoir goes on to explain the problematic nature of the term "female" as it is used and defined by men. To be "female" according to patriarchal tradition is to be "lacking" or "other," defining women not by what they are but by what they are not--men: "The term 'female' is derogatory not because it emphasizes woman's animality, but because it imprisons her in her sex" (SS 3). She is imprisoned because the dominant male society forces upon her all the truths about female sex in the animal kingdom and decides that these are the causes for women's inferiority in civilized society. Beauvoir offers a few examples of animal behaviors that are associated with human females and are qualities that are to be feared and controlled: "The word female brings up in his mind a saraband of imagery. . the monstrous and swollen termite queen rules over the enslaved males. . . the female preying mantis and the spider, satiated with love, crush and devour their partners" (SS 3). These images are violent in nature as these particular female beings in the animal kingdom oppress their male counterparts. Beauvoir continues by detailing examples of female trickery in the animal kingdom, trickery used to dupe males into procreation: "the bitch in heat runs through the alleys, trailing behind her a wake of depraved odors, the she monkey presents her posterior immodestly and then steals away with hypocritical coquetry" (SS 3). These images again are negative and are projected upon human females as qualities inherent in the female sex and thus the female sex is not to be trusted, but rather feared and controlled. Beauvoir argues that "Females sluggish, eager, artful, stupid, callous, lustful, ferocious, abased—man projects them all at once upon woman. And the fact that she is female" (SS 4). Why is this negative way of defining women so useful, or even necessary in society? What benefit does the patriarchy achieve from oppressing women so consistently throughout history? A finite binary 
gender system in which one gender has complete dominion over the other was the only way for the patriarchy to strip women of economic and cultural power, namely control over property and children, and create for them submissive roles from which they could escape escape. Because of their inability to overpower men physically, women have had very little means of enforcing their will. As Woolf states in Three Guineas, "Our class is the weakest of all the classes in the state. We have no weapon with which to enforce our will" (TG 13). By relegating women to the same level as objects, men in society were able to trade them like livestock, taking ownership over them and their bodies.

In her chapter "Patriarchal Times and Classical Antiquity," Beauvoir explains, "Woman was dethroned by the advent of private property, and her lot through the centuries has been bound up with private property. ... When it is admitted that a woman's children are no longer hers, by the same token they have no tie with the group from whence the woman has come" (SS 82). With no rights to own her own property, a woman has no power against the men in her life, and she is forced to succumb to their fastidious will because their will is backed up by laws of the society. She has no escape, for if she leaves her husband's or father's house, as Woolf's Judith Shakespeare did, she is still under the control of the patriarchy, and she will either be returned to her male owner, or destroyed. Beauvoir goes on to discuss the traditional history of the institution of marriage and its influence on the limited rights of women in society:

She is torn up by the roots from the group into which she was born, and annexed by her husband's group; he buys her as one buys a farm animal or a slave; he imposes his domestic divinities upon her; and the children born to her belong to the husband's family. If she were an inheritor, she would to an excessive degree transmit the wealth of her father's family to that of her husband, so she is carefully excluded from the succession. (SS 82)

In a society built upon these proprietary principles, how can women emerge and become 
equal in their education, profession and financial status? As Beauvoir states, "When the family and private patrimony remain beyond question the bases of society, then woman remains totally submerged" (SS 84). Women are doomed before they can even emancipate themselves, for the building blocks of society were formed to lock them in the private sphere under the dominion of male authority. And even if she could escape into the world, she would find herself thrust into a society devoted to male interests. With traditional society designed against her interests, it seemed that a woman had very little choice but to remain under the thumb of the patriarchy. However, with social transformations effected by the First World War and then World War II, which reshaped the way men and women were expected to act in society, women were given a chance to redefine the self, outside of biological constraints. Suddenly, the male-dominated society needed her to leave her home and enter the work force because so many men had to abandon their positions in the work force and fight for their countries. This opened the door for women to reconsider their place in the world, for the patriarchy was dictated by military action and had little concern about whether or not women were remaining in their traditional roles. However, using the traditional ways of talking about and defining women's experiences was still problematic, for all modes of expression were laden with historical biases and patriarchal domination.

Simone de Beauvoir believed that "one is not born but rather becomes a woman," and this statement implies that there can be some choice in how a human female defines herself without considering her biological make-up. If a female is barren and unable to reproduce, does that make her a woman or something else? And if a female gives birth, but has very little physical or emotional responsibility for that child due to her financial 
ability to employ a nurse, does that make her socially comparable to a man? Both Virginia Woolf and Simone de Beauvoir realized that biological sex was not a choice, but more options for how a human being defines the self were necessary. Not only were more options needed, especially now that society was shifting in the wake of changes precipitated by the wars, but the time was right for a conversation to open up about the possibilities for change. It was no longer sufficient to utilize the binary gender system, for its history was laden with oppression and bias, and therefore something new became necessary. The antiquated sex-role stereotypes of man and woman were problematic in defining people who were assuming new roles and cultivating new experiences that needed to be interpreted outside of traditional gender roles. Woolf and Beauvoir were aware of this need and focused more on the existential moments of a person's life rather than on essentialist biology. Considering the binary gender system obsolete, Woolf and Beauvoir attempted to write something other than premises that defined the male as norm and female as other, for such categories had failed to represent the New Woman as she emerged from the private sphere into the public. They certainly were not interested in arguing for the melding of women into men, for that would merely perpetuate all the problems of the patriarchal society. Instead, Woolf and Beauvoir seem to be arguing for (An)Other gender to designate a person who is conscious of experiences and is able to interpret those experiences outside of male/female social constrictions. (An)Other gender offers both men and women a more malleable and fluid philosophical category in which to place themselves and explore their experiences without the hindrances imposed by the binary gender system so prominent in society. For (An)Other gender, choice is the primary tool for defining the self, for people can choose which moment is important, and 
which experience is meaningful. No longer using biological sex characteristics to determine possibilities, women are freed from the prescribed roles of wife, mother, and lover, to define themselves in whatever way they deem appropriate. Perhaps (An)Other gender would consider motherhood an important characteristic for the self, but that decision would come from within versus being forced upon a woman from outside herself. "One is not born, but rather becomes. ..." 


\section{REFERENCES}

Abbott, Elizabeth. "What is Equality?” Woman's Leader. (February 11, 1927)

Allen, Ann Taylor. Feminism and Motherhood in Western Europe 1890-1970. New York: Palgrave, 2005.

--. Women in Twentieth-Century Europe. New York: Palgrave, 2008.

Althusser, Louis. "Ideology and Ideological State Apparatuses." Lenin and Philosophy and Other Essays, Monthly Review Press: (1971).

Bair, Diedre. "Women's Rights in Today's World: An interview with Simone de Beauvoir. 1984 Britannica Book of the Year. Chicago: Encyclopedia Britannica, Inc., 1984.

Badenhausen, Richard. "Mourning Through Memoir: Trauma, Testimony, and Community in Vera Brittain's Testament of Youth." Twentieth-Century Literature. 49.4 (2003): $421-448$.

Bazin, Nancy Topping. Virginia Woolf and the Androgynous Vision. New Brunswick: Rutgers University Press, 1973.

Beauvoir, Simone de. Ethics of Ambiguity. Trans. Bernard Frechtman. 1947. Secaucus, N.J.: The Citadel Press, 1964.

--. Memoirs of a Dutiful Daughter. Trans. James Kirkup.1958. New York: Harper \& Row, 1958.

--. “Monologue." The Woman Destroyed. Trans. Patrick O'Brian. 1967. New York: 
Pantheon, 1987.

-- The Second Sex. Trans. H.M. Parshley. 1949. New York: Vintage, 1989. (cited at SS)

--. When Things of the Spirit Come First: Five Early Tales. Trans. Patrick O'Brian. 1979.

New York: Pantheon, 1982.

Berger, Peter. The Sacred Canopy: Elements of a Sociological Theory of Religion. New York: Double Day, 1967.

Bennett, Paula. "The Mother's Part: Woolf and Morrison." Narrating Mothers:

Theorizing Maternal Subjectivities. Ed. Brenda O. Daly and Maureen T. Reddy. Knoxville: University of Tennessee Press, 1991

Bradshaw, David and Kevin J. H. Dettmar, ed. A Companion to Modernist Literature and Culture. Malden, MA: Blackwell Publishing, 2006.

Briggs, Julia. Virginia Woolf: An Inner Life. Orlando: Harcourt, 2005.

Brittain, Vera. Testament of Youth. New York: Macmillian, 1933.

Brooks ,W. K.. The Law of Heredity. 1883.

Carroll, Bernice A. "“To Crush Him in Our own Country': The Political Thought of Virginia Woolf." Feminist Studies, 4.1 (1978): 99-132.

Cixous, Hélène. "The Laugh of the Medusa." New French Feminisms. Eds. Elaine Marks and Isabelle de Courtivron. New York: Schocken, 1981.

Cixous, Hélène and Catherine Clément. The Newly Born Woman. Theory and History of Literature, v.24. University of Minnesota Press: Minneapolis, 1986.

Cohen, Miriam and Michael Hanagan. "The Politics of Gender and the Making of the Welfare State, 1900-1940: A Comparative Perspective." The Journal of Social History, 24.3 (1991):469-484. 
DeMeester, Karen. "Postwar recovery in Mrs. Dalloway." Virginia Woolf and Trauma:Embodied Texts. Eds. Suzette Henke and David Eberly. New York: Pace University Press, 2007.

Farwell, Marilyn. "Virginia Woolf and Androgyny." Contemporary Literature. 16.4(1975): 433-451.

Fawcett, Millicent Garrett. The women's victory -- and after: personal reminiscences, 1911-1918. London: Sidgwick \& Jackson, Ltd, 1920.

Froula, Christine. "Mrs. Dalloway's Postwar Elegy: Women, War and the Art of Mourning." Virginia Woolf and the Bloomsbury Avant-Garde. New York: Columbia University Press, 2005.

Fussell, Paul. The Great War and Modern Memory. New York: Oxford University Press, 2000.

Garvey, Johanna. "Difference and Continuity: The voices of Mrs. Dalloway." College English. 53.1(1991):59-76.

Gilbert, Sandra and Susan Gubar. No Man's Land: The Place of the Woman Writer in the Twentieth Century. 3 vols .New Haven: Yale University Press, 1988.

Gilbert, Sandra M. "Soldier's Heart: Literary Men, Literary Women, and the Great War." Signs: Journal of Women in Culture and Society, 8.3(1983): 422-450.

Henke, Suzette A. James Joyce and the Politics of Desire. New York: Routledge, 1990.

Hussey, Mark, ed. Virginia Woolf and War: Fiction, Reality, and Myth. Syracuse :Syracuse University Press, 1991.

Irigaray, Luce. This Sex Which is Not One. Ithaca: Cornell University Press, 1985.

Joyce, James. Ulysses. New York: Random House, 1986. (cited as $U$ ) 
Kent, Susan Kingsley. "The Politics of Sexual Difference: World War I and the Demise of British Feminism." Journal of British Studies, 27.3(1988): 232-253.

Kristeva, Julia. "About Chinese Women. The Kristeva Reader. Ed. Toril Moi. New York: Columbia University Press, 1986.

--. "Woman Can Never Be Defined." New French Feminisms: An Anthology. Eds. Elaine Marks and Isabelle de Courtivron. Schocken Books: New York, 1981.

Kruks, Sonia. "Simone de Beauvoir and the Limits to Freedom." Social Text, 17(1987): 111-122.

Lawrence, D. H. Women in Love. London: Penguin, 1995. (cited as WL)

Le Doeuff, Michèle. "Women and Philosophy." French Feminist Thought: A Reader. Ed. Toril Moi. Oxford: Basil Blackwell, 1987.

Lee, Hermione. Virginia Woolf. New York: Vintage Books/Random House, 1996.

Levenson, Michael, ed. The Cambridge Companion to Modernism. Cambridge :Cambridge University Press, 1999.

Light, Alison. Mrs. Woolf and the Servants: An Intimate History of Domestic Life in Bloomsbury. New York: Bloomsbury Press, 2008.

Millett, Kate. Sexual Politics. Garden City, New York: Doubleday, 1970.

Moi,Toril. “ 'Independent Women' and 'Narratives of Liberation"” Simone de Beauvoir: A Critical Reader. Ed. Elizabeth Fallaize. New York: Routledge, 1998.

--. Simone de Beauvoir: The Making of an Intellectual Woman. $2^{\text {nd }}$ ed. Oxford: Oxford University Press, 2008.

--. "What is a Woman?" What is a Woman and Other Essays. Oxford: Oxford University Press, 1999. 
Offen, Karen."Depopulation, Nationalism, and Feminism in Fin-de-Siècle France." The American Historical Review, 89.3 (1984): 648-676.

--. "Ernest Legouvé and the Doctrine of 'Equality in Difference' for Women: A Case Study of Male Feminism in Nineteenth-Century French Thought." Journal of Modern History 58 (1986): 452-484.

--. "The Second Sex and the Baccalaureate in Republican France, 1880-1924" French Historical Studies, 13.2 (1983): 252-286.

Pankhurst, Christabel. Pressing Problems of the Closing Age.1924.

Patterson, Yolanda A. "Simone de Beauvoir and the Demystification of Motherhood." Yale French Studies, 72(1986): 87-105.

Poole, Roger. The Unknown Virginia Woolf. Cambridge: Cambridge University Press, 1978.

Rado, Lisa. "Would the Real Virginia Woolf Please Stand up? Feminist Criticism, the Androgyny Debates, and Orlando." Women's Studies, 26(1997):147-169.

Rathbone, Eleanor. "The Old and New Feminism," Women's Leader (March 13, 1925).

Rowley, Hazel. Tête-à-Tête: Simone de Beauvoir and Jean Paul Sartre. New York: Harper Collins, 2005.

Rosner, Victoria. Modernism and the Architecture of Private Life. New York: Columbia University Press, 2005.

Sand, George. Correspondence, 1812-1848. 8 vols. Ed. Georges Lubin. Paris, 19641971.

Sartre, Jean-Paul. "Existentialism is a Humanism." Existentialism from Dostoevsky to Sartre. New York: Meridian, 1965. 
Shanley, Mary Lyndon. "Suffrage, Protective Labor Legislation, and Married Women's

Property Laws in England." Signs: Journal of Women in Culture and Society. 12.1(1986).

Scott, Bonnie Kime, ed. The Gender of Modernism: A Critical Anthology. Bloomington: Indiana University Press, 1990.

--. "Modernism and Gender. A Companion to Modernist Literature and

Culture. Ed. David Bradshaw and Kevin J.H. Dettmar. Maldne: Blackwell, 2006.

-.. "Refiguring the Binary, Breaking the Cycle: Rebecca West as Feminist Modernist."

Twentieth-Century Literature. 37.2(1991): 169-191.

Sherry, Vincent, ed. The Cambridge Companion to the Literature of the First World War. Cambridge: Cambridge University Press, 2005.

Shiach, Morag ed. The Cambridge Companion to the Modernist Novel. Cambridge: Cambridge University Press, 2007.

Stern, Daniel. Histoire de la Revolution de 1848. Paris, 1851.

Taylor, Nancy. "Erasure of Definition: Androygny in Mrs. Dalloway." Women's Studies. 18: (1991):367-377.

Tate, Trudi. Modernism, History, and the First World War. Manchester: Manchester University Press, 1998.

West, Rebecca. "On a Form of Nagging." Time and Tide (October 31, 1925).

--. The Return of the Soldier. New York: The Dial Press, 1980. (cited as RS)

Woolf, Virginia. A Room of One's Own. 1929. Orlando: Harcourt, 1981. (cited as $A R O O)$

--. Moments of Being. San Diego: Harcourt, 1985. (cited as MB) 
--. The Common Reader. 1925. San Diego: Harcourt, 1984. (cited as CR)

--.The Complete Shorter Fiction of Virginia Woolf. San Diego: Harcourt, 1989. (cited as $C S F)$

--. The Diary of Virginia Woolf. 5 vols. Ed. Anne Oliver Bell. New York: Harcourt, 1978-1980.

--. Mrs. Dalloway. 1925. Orlando: Harcourt, 2005. (cited as MD)

--. Orlando. 1928. Orlando: Harcourt, 1956. (cited as $O$ )

--. To The Lighthouse. 1927. San Diego: Harcourt, 1981. (Cited as TTL)

--. Three Guineas. 1938. Orlando: Harcourt, 1966. (Cited as TG)

--. The Waves. 1931. San Diego: Harcourt, 1959. (cited as Waves)

Wussow, Helen. The Nightmare of History: The Fictions of Virginia Woolf and D. H. Lawrence. Bethlehem: Lehigh University Press, 1999.

Zerilli, Linda M.G. "A Process without a Subject: Simone de Beauvoir and Julia Kristeva on Maternity." Signs: Journal of Women in Culture and Society. 18.1(1992): 111135

Zwerdling, Alex. Virginia Woolf and the Real World. Berkley: University of California Press, 1986. 


\section{CURRICULUM VITAE}

NAME: Anna Catherine Stamp

ADDRESS: 2909 Tremont Drive

Louisville, KY 40205

DOB: Louisville, Kentucky- August 25, 1979

EDUCATION

\& TRAINING: $\quad$ B.S., English

University of Louisville

1997-2001

M.A., Humanities

University of Louisville

2001-2003

Ph.D., Humanities

University of Louisville

2004-2011

AWARDS: 2003 M.A. Humanities Award

ORGANIZATIONS: Association of Humanities Academics

University of Louisville

PRESENTATIONS: "Fanaticism: Recollections, Representations, Reactions"

2011 AHA Conference, University of Louisville 